\title{
Geology of the
}

\section{Imuruk Lake Area}

Seward Peninsula

\section{Alaska}

By D. M. HOPKINS

CONTRIBUTIONS TO GENERAL GEOLOGY

GEOLOGICAL SURVEY B ULLETIN 1141 - C

Prepared in cooperation with the U.S. Army Corps of Engineers

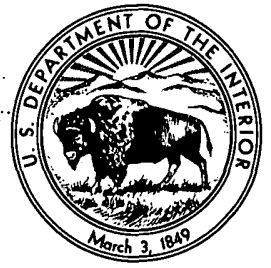


UNITED STATES DEPARTMENT OF THE INTERIOR

STEWART L. UDALL, Secretary

\section{GEOLOGICAL SURVEY}

Thomas B. Nolan, Director 


\section{CONTENTS}

Abstract
Introduction
$\quad$ Climate
$\quad$ Vegetation
Animals
Human occupation
Physiography
$\quad$ Imuruk .Lake lava plateau
$\quad$ Bendeleben Mountains.
$\quad$ Suzitrin flats
Seward Peninsula uplands
Regional geology
Paleozoic and Mesozoic rocks

Schist unit_...

Lithology _...

Calcite-muscovite schist . . . . . .

Graphitic schist. . .

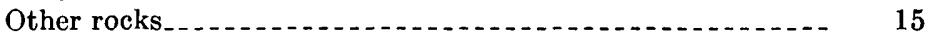

Age

Metalimestone unit. ...

Lithology

Age

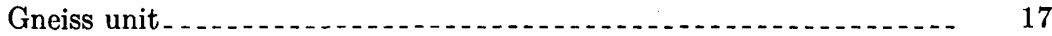

Lithology

Biotite-hornblende-epidote gneiss . . . . . . . . . 18

Hornblende-microcline gneiss............. 18

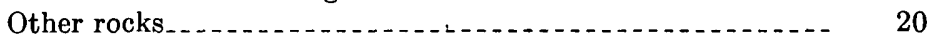

Grade of metamorphism

Age

Granitic plutons... 22

Lithology

Contact relationships.

Origin

Age

Structure

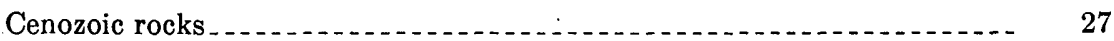

Unconsolidated sediments

Kougarok gravel $\ldots \ldots$

Stratigraphy and lithology

Fossils and age..... 33

Glacial drift. .

Nome River glaciation

Salmon Lake glaciation 
Cenozoic rocks-Continued

Unconsolidated sediments-Continued Page

Windblown silt _ C35

Lithology $\ldots \ldots$

Mineralogy . . . .

Age and origin

Alluvium and colluvium .............................. 42

Gravel ...

Stratified silt and peat. ................................. 43

Lacustrine sediments

Imuruk Lake. . . . . .

Other lakes........ 46

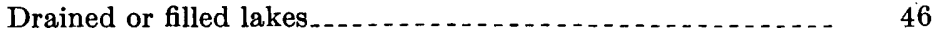

Diatomite in valley of Andesite Creek............... 46

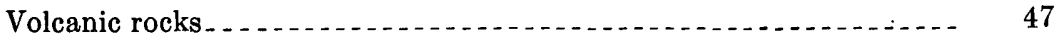

Stratigraphy ...

Kugruk volcanics........

Imuruk volcanics...

Gosling volcanics.

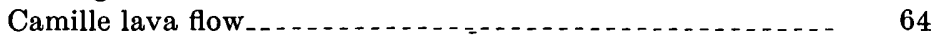

Lost Jim lava flow

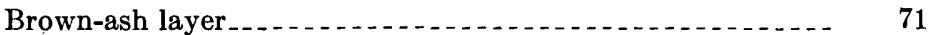

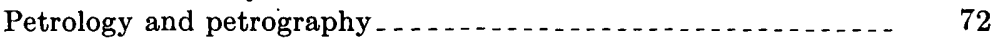

Olivine andesite and basalt . .

Hypersthene andesite . . . . 76

Pilotaxitic andesite $\ldots \ldots$

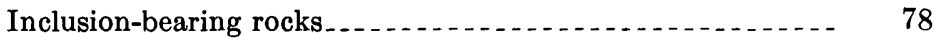

Composition .

Origin

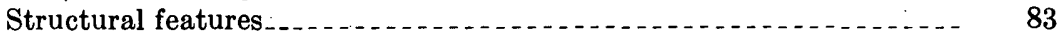

Geologic history

Permafrost. . . . . . .

Ground-water hydrology . . .

Alluvial gravel ...

Metalimestone

Kougarok gravel $\ldots \ldots \ldots 1$

Imuruk volcanics.

Gosling volcanics, Camille lava flow; and Lost Jim lava flow _..... 93

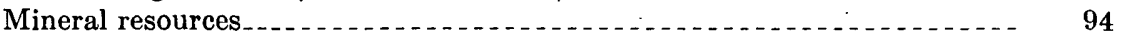

Gold placers.

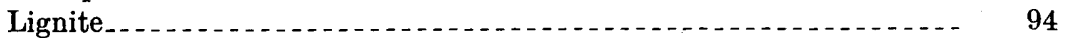

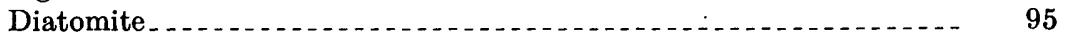

Literature cited........ 95

Index . 


\section{ILLUSTRATIONS}

[Plates are in pocket]

Plate 1. Geologic map of the Imuruk Lake area.

2. Volcanic and structural features of late Cenozoic age on Seward Peninsula.

3. Glaciated areas and areas covered by windblown silt on Seward Peninsula.

4. Volcanic vents, faults, and warped surfaces in and near the Imuruk Lake area.

Frgure 1. Index map of Seward Peninsula .

2. Physiographic subdivisions of the Imuruk Lake area

3. Panorama of the Bendeleben Mountains..............

4. Porphyroblasts of hornblende and microcline...........

5. Sketch of a compound pegmatite dike

6. Weathered bedrock beneath Kougarok gravel ...........

7. Mechanical composition of the fine-grained mantle in the

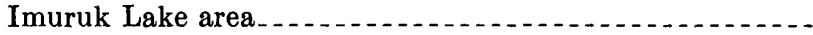

8. : Late Quaternary sediments in the valley of Black Gulch...---

9. Geologic map of the canyon of the Kugruk River........

10. Spheroidal weathering in Kugruk volcanics.............

11. Twin . Calderas and surrounding lava dome of Gosling volcanics

12. Geologic map of Virginia Butte and vicinity . .

13. Comparison between the surfaces of the Gosling volcanics and the Camille flow.

14. Comparison between the surfaces of the Lost Jim and.Camille flows

15. General view of the Lost Jim flow

\section{TABLES}

TABLE 1. Mineral composition of fine-grained mantle in the Imuruk Lake

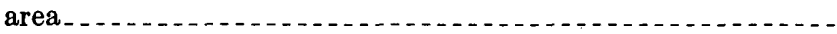

2. Chemical analysis and normative minerals of an olivine basalt lava flow. 



\title{
CONTRIBUTIONS TO GENERAL GEOLOGY
}

\section{GEOLOGY OF THE IMURUK LAKE AREA, SEWARD PENINSULA, ALASKA}

\author{
By D. M. Hopkins
}

\begin{abstract}
The Imuruk Lake area is underlain by metamorphic rocks of Paleozoic age, granitic rocks of probable Late Jurassic or Early Cretaceous age, and sediments and lava flows of late Cenozoic age. The Paleozoic metamorphic rocks include schist of 'several types assignable to Eskola's green-schist facies, gneiss assignable to Eskola's amphibolite facies, and metalimestone. The schist unit includes rocks that are older and younger than the metalimestone unit. The rocks of the gneiss unit are believed to be stratigraphically equivalent to part of the rocks in the schist unit and to have acquired much of their present texture and mineralogy during the emplacement of the Kuzitrin Lake batholith. The granitic rocks of probable late Mesozoic age include the small Black. Butte stock and the Kuzitrin Lake batholith, a large body of granitic rocks exposed in the northern. Bendeleben Mountains south of Kuzitrin Lake that apparently extends northward beneath the Imuruk Lake lava plateau to the Asses Ears.

The Kougarok gravel of late Tertiary and Pleistocene(?) age underlies the northwestern part of the Kuzitrin flats and consists of a basal gravel member locally more than 187 feet thick, a thin middle member composed of peaty lignite, and an upper gravel member 3 to 60 feet thick. The middle member contains a rich pollen and wood flora consisting of a mixture of coniferous and deciduous trees, including representatives of several genera that now reach their northern limits in latitudes $5^{\circ}$ to $15^{\circ}$ south of Seward Peninsula. Similar pollen floras in the valley of the Aldan River, Yakutia, Siberia, and in the northern Alaska Range are of late Miocene or early Pliocene age. The upper member contains poplar and either spruce or larch wood and may be early Pleistocene in age.

Pleistocene sediments include glacial deposits, windblown silt, stratified silt and peat, alluvial gravel, and lacustrine sediments. Till and outwash of the Nome River (Illinoian) and Salmon Lake (Wisconsin) glaciations are found in and along the north front of the Bendeleben Mountains. Windblown silt covers the pre-Cenozoic rocks, the Kougarok gravel, and the older lava flows throughout much of the Imuruk Lake area. The stratified silt and peat consists largely of windblown silt that has been washed downslope to form fans, aprons, and-in places-valley-fill deposits. The alluvial gravel underlies the flood plains and low terraces of the larger streams.
\end{abstract}


Lake deposits are found in the many existing lakes and in the basins of several large filled or drained lakes. Imuruk Lake is adjoined by three systems of abandoned shoreline features consisting of wave-cut scarps, and of terraces composed of beach gravel, and lacustrine silt and peat. The two older systems, formed during the Nome River (Illinoian) and Salmon Lake (Wisconsin) glaciations, have been irregularly warped; the youngest system, formed in Recent time, is virtually horizontal. Imuruk Lake drained westward to the Noxapaga River when the older shorelines were occupied; its present outlet to the Kugruk River was formed when the intermediate shoreline features were tilted near the end of the Wisconsin time.

Volcanic rocks of late Cenozoic age cover most of the central part of the area. Five volcanic formations are distinguished on the basis of weathering profiles, degree of frost brecciation, and extent and thickness of the mantle of windblown silt: The Kugruk volcanics of late Tertiary or possibly early Pleistocene age; the Imuruk volcanics of early and middle Pleistocene age; the Gosling volcanics, emplaced during and after the interglacial interval between the Nome River (Illinoian) and Salmon Lake (Wisconsin) glaciations; the Camille flow, emplaced near the end of the Salmon Lake glaciation; and the Lost Jim lava flow, emplaced within the last few thousand years. Most of the volcanic rocks have compositions near the boundary between basalt and andesite, and most are free of inclusions of any kind. However, several vents distributed in a northwest-trending belt from Blueberry Dome to Trail Creek have given rise to lavas ranging in composition from mafic basalt to pilotaxitic andesite that contain abundant angular inclusions of dunite, magnetite, granitic rocks, and schist. Most of the volcanic rocks probably arose directly from great depths, but the more highly differentiated rocks of the inclusion-bearing belt may have been detained in a magma chamber at shallow depth. Volcanic eruptions in the Imuruk Lake area probably have been spaced at intervals of five to ten thousand years throughout most of late Cenozoic time.

Tectonic disturbances of late Cenozoic age are recorded by a deformed erosion surface, warped lake basins, and fault scarps that cut lava flows. The volcanic vents are distributed in major northwest-trending swarms and minor northeast-trending swarms, parallel to but not coincident with the observed surface faults.

Perennially frozen ground is present throughout the Imuruk Lake area but is less than 70 feet thick in the one place where deep subsurface information is available. Hydrologic evidence suggests that the more permeable geologic units contain interconnecting thawed zones.

Ground water is available in the metalimestone, the Kougarok gravel, the lava flows, and the flood-plain gravel of the larger streams. The distribution of the ground water is complicated by the presence of permafrost, by the contrasting permeabilities of various geologic materials, and by the irregular initial topography of the lava flows. Mineral resources include auriferous stream gravel, lignite, and diatomite.

\section{INTRODUCTION}

The Imuruk Lake area (pl. 1) until recently has been one of the geologically less well explored parts of Seward Peninsula, Alaska. Most of the area is mantled by lava flows of Quaternary age, and a 
difficult terrain and a lack of promising mineral resources in those parts of the area underlain by volcanic rocks have discouraged prospecting and scientific exploration. Parts of the Imuruk Lake area are.described by Moffit (1905), Collier (1902), and Collier and others (1908).

The existence of large expanses of nearly flat terrain on some of the younger lava flows led during the mid-1940's to a brief consideration of the possibility of locating a military airfield in the Imuruk Lake area and to an investigation of the bedrock and surficial geology and of the permafrost conditions by a U.S. Geological Survey party during 1947 and 1948. Geologic, geomorphic, botanical, and zoological studies were conducted. Base camps were established at large lakes accessible to amphibious aircraft and at mining camps on the periphery of the area. Detailed studies were made within a radius of several miles of each camp, and reconnaissance traverses were made over parts of the intervening areas during back-packing trips of 2 to 6 days' duration. Geologic mapping in areas not covered by ground traverses is based on observations made during airplane recomnaissance and on study of aerial photographs. Brief visits were also made to the Imuruk Lake area by me in 1949 and R. S. Sigafoos in 1952.

This report describes the results of the geologic mapping. Other aspects of the fieldwork have been published elsewhere (Hopkins, 1949; Hopkins, 1959b; Hopkins and Sigafoos, 1951; Quay, 1951).

Fieldwork for this study was financed in part by the Office of the Chief of Engineers, U.S. Army. The 10th Search and Rescue Squadron, U.S. Air Force, furnished air transportation between Nome and Imuruk Lake.

I was assisted in the field by A. T. Fernald, E. H. Muller, and J. F. Seitz, geologists; R. S. Sigafoos, botanist; and W. B. Quay and J. G. Sieh, zoologists. Assistance and hospitality were rendered by John Cross, pilot; D. H. Stewart and Charles Garrett of the Casadepaga Gold Co.; and John and Frank Whaley of the Rainbow Mining Co. Special thanks are due the radio operators of Civil Aeronautics Administration radio station KYWK at Kotzebue, Alaska, for their kindness during both field seasons.

Helpful advice and criticism were contributed by M. P. Billings, R. F. Black, the late Kirk Bryan, R. E. Detterman, Marian Guggisberg, T. N. V. Karlstrom, P. L. Killeen, Clyde Wahrhaftig, and J. R. Williams. The late Joan P. Hopkins studied the petrography of most of the rocks of the Imuruk Lake area. 


\section{GEOGRAPHY}

The Imuruk Lake area encompasses 1,100 square miles in the central part of the Bendeleben quadrangle (Alaska Topographic Series, scale 1:250,000, U.S. Geol. Survey, 1950) in the north-central part of Seward Peninsula (fig. 1). The area is also covered by the following quadrangles, scale 1:63,360: Bendeleben B2 through B5, $\mathrm{C} 2$ through $\mathrm{C} 5$, and D2 through D4. Imuruk Lake lies approximately at lat $65^{\circ} 36^{\prime} \mathrm{N}$., long $163^{\circ} 12^{\prime} \mathrm{W} .-100$ miles northeast of Nome and 60 miles south of the Arctic Circle. The area has no permanent residents. Imuruk Lake can be reached by tracked vehicles traveling overland from the heads of graded roads on the upper Inmachuk River, 18 miles to the north, and on the Kougarok River, 40 miles to the west. Small aircraft can land on several lakes within the area or on small airstrips near the Noxapaga and Inmachuk Rivers. Amphibious aircraft as large as the Navy PBY can land and take off on Imuruk Lake.

\section{CLIMATE}

The climate of the Imuruk Lake area is generally similar to the climate at Candle, 45 miles to the northeast, and is characterized by cool summers and very cold winters. The mean annual temperature is probably about $20^{\circ} \mathrm{F}$. The absolute maximum temperature recorded at Candle prior to 1943 is $85^{\circ}$; the absolute minimum is $-60^{\circ}$. The mean annual precipitation is probably between 7 and 8 inches, of which about 25 percent falls as snow. More than 50 percent of the annual precipitation occurs during a well-defined rainy season extending from July through September. The climate is described in more detail in Hopkins and Sigafoos (1951, p. 55-58).

\section{VEGETATION}

The vegetation throughout most of Seward Peninsula is tundra. Spruce forest is confined to the southeastern part of the Peninsula (fig. 1); cottonwood trees and tall alder and willow shrubs are found in favorable sites farther north and west.

The Imuruk Lake area lies northwest of the forest. Half a dozen groves, each containing from 10 to 100 small cottonwood trees, are known within the area. Small thickets of alders (Alnus crispa) are present in a few places on steep mountain slopes and on some of. the younger lava flows, and willows (Salix alaxensis) 5 to 10 feet tall grow on the flood plains of the largest streams. Elsewhere the vegetation consists chiefly of (1) Dryas and heath mats and tufted plants growing a few inches high in otherwise bare ground; (2) dwarf birch (Betula nana) and several willow species forming shrub thickets $11 / 2$ to 3 feet high; (3) assemblages of cottongrass 


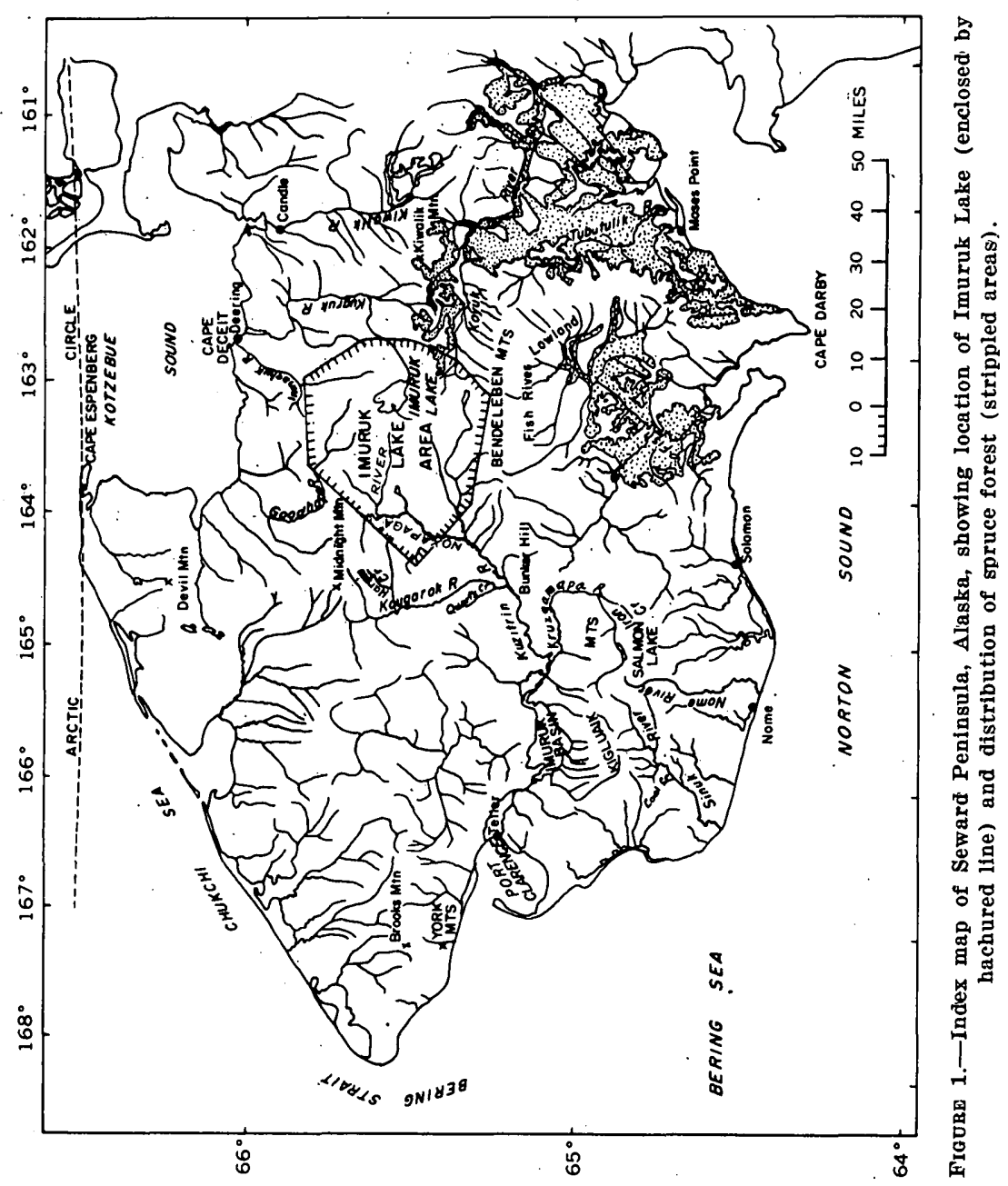


(Eriophorum vaginatum) tussocks, dwarf birch, and heath shrubs; and (4) dense sod-forming sedges, mostly species of Carex. Dryasheath tundra is found on well-drained rocky or gravelly soils; shrub thickets on river terraces and the best drained hill slopes; $;$ cottongrass tussocks on moderately well drained slopes underlain by silty soils; and sedge sod on poorly drained hill summits and slopes, in swales, in lowland marshes, and around the edges of ponds. The vegetation in the Imuruk Lake area is described in more detail by Hopkins and Sigafoos (1951, p. 63-66).

\section{ANIMALS}

All large mammals native to Seward Peninsula (Quay, 1951), including grizzly bears, wolverines, foxes, and wolves, are present in the Imuruk Lake area. Weasels, at least two species of shrews, ground squirrels, several species of mice and lemmings, muskrats, and rabbits are common small mammals. Bones of moose in low terraces of Recent age at Imuruk Lake suggest that individual moose occasionally wander far beyond their usual western limit in the upper valley of the Kiwalik River.

A large herd of reindeer belonging to the village of Deering formerly grazed in the Imuruk Lake area, but it was scattered and exterminated during the early 1940's. The deer were evidently herded on the lichen-covered rubble and bedrock of the younger lava flows, for fresh-looking bones, skeletons, and hair are abundant in crevices and between blocks in the rubble; reindeer are probably responsible for the recently overturned boulders that are scattered sparsely over these surfaces (p. C63).

Aquatic life in the Imuruk Lake area includes several species of fish and mollusks. Grayling are found in Imuruk Lake and grayling and rainbow trout abound in many streams. Pike are reported in the Noxapaga River and in Muskellunge Creek (pl. 1). Alaska blackfish (Dallia pectoralis) and nine-spined stickleback (Pungitius pungitius) are common in Lava Lake and in some small lakes (W. B. Quay, written communication, 1951). Several mollusks ${ }^{1}$ were collected in Imuruk Lake and smaller lakes nearby, including: Pelecypoda :

\section{Pisidium lilljeborg Clessin \\ Pisidium idahoense Roper \\ Sphaerium tenue nitidium Clessin}

1 Gastropods identifled by Henry van der Schalle, Division of Molluscs, Museum of Zoology, University of Michigan; pelecypods identified by $H$. B. Herrington, Keene, Ontario. The specimens have been deposited in the National Museum. 
Gastropoda :

Gyraulis deflectus Say

Physa sp.?

Lymnaea randolphi F. C. Baker

Valvata lewisi helicoidea Dall

\section{HUMAN OCCUPATION}

A cave at Trail Creek contains the remains of a succession of human cultures ranging in age from about 6,000 years to a few hundred years (American Antiquity, 1950; 1951). Included are horizons representing the Denbigh flint complex, the oldest wellknown human culture in northwestern Alaska.

Eskimos from villages on Kotzebue Sound hunted caribou in the Imuruk Lake area until about 1850 , when caribou became nearly extinct on Seward Peninsula (Dall, 1870, p. 147). Village sites and caribou traps at Cloud Lake, Skeleton Butte, Twin Calderas, and Kuzitrin Lake, lichen-covered "jumping stones" at two points on the Lost Jim flow; and lichen-covered cairns on nearly every major hill and cinder cone testify to the former Eskimo activity in the area.

Caucasian occupation began about 1900 with the development of gold placers on the Inmachuk River and its tributaries at the north edge of the Imuruk Lake area and on tributaries of the Goodhope and Noxapaga Rivers heading in the uplands at the west edge of the Imuruk Lake area. Part of the discharge of Imuruk Lake was diverted for many years from the head of the Kugruk River through the Fairhaven Ditch (pl. 1) to the head of the Inmachuk River (Henshaw and Parker, 1913, p. 25-26).

\section{PHYSIOGRAPHY}

The Imuruk Lake area lies athwart the divide between northward drainage to Kotzebue Sound and southward drainage to Bering Sea and Norton Sound (fig. 1). Five major streams-the Kugruk, the Inmachuk, the Goodhope, the Kuzitrin, and the Koyuk Rivers--head within the area. The Imuruk Lake area includes parts of the five following physiographic units: The Imuruk Lake lava plateau, the Seward Peninsula uplands, the Bendeleben Mountains; the Koyuk Valley, and the Kuzitrin flats (fig. 2).

\section{IMURUK LAKE LAVA PLATEAd}

The Imuruk Lake lava plateau is an area of gently undulating hills and lowlands ranging in altitude from 150 to 1,837 feet. The 


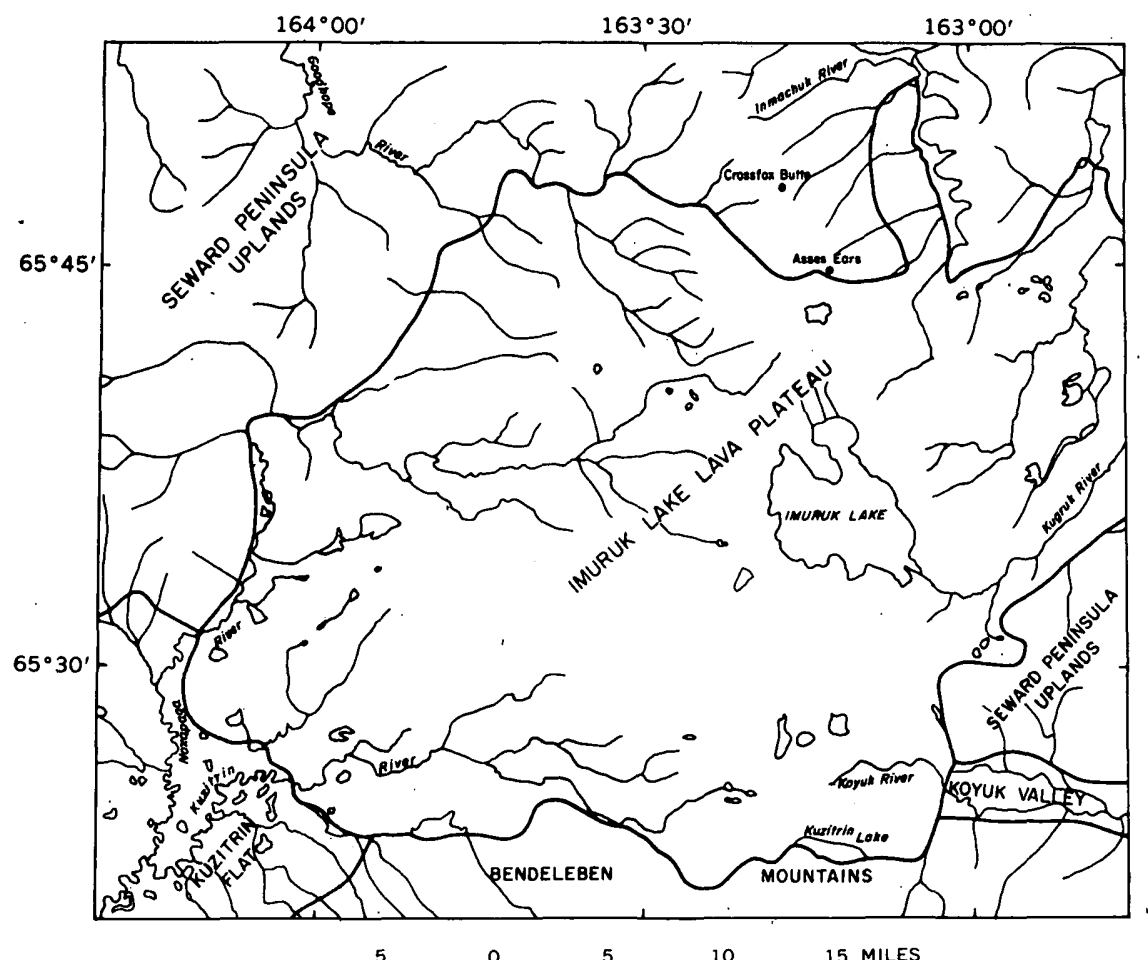

Figure 2.-Physiographic subdivisions of the Imuruk Lake area, Seward Peninsula, Alaska.

surface of Imuruk Lake stands 1,021 feet above sea level. The lava plateau is almost entirely encompassed within the area covered by plate 1 . Rolling hills at the east, north, and west margins of the lava plateau merge with the higher hills of the Seward Peninsula uplands. The southwest corner of the plateau slopes imperceptibly into the Kuzitrin flats. The Bendeleben Mountains rise abruptly from the south border.

In detail, the lava plateau has a gently undulating surface, with local relief ranging from 50 to 800 feet. The most conspicuous relief features are isolated hills with broad dome-shaped summits and smooth slopes, rarely steeper than $10^{\circ}$. Most of the larger hills consist of granitic or metamorphic rocks that have not been buried beneath the plateau lavas, but some are ancient volcanic centers and 
others are fault blocks. The intervening lowlands consist of broad swells and swales in some places and of swampy, lake-dotted basins in others. The larger relief features in the lowlands are the initial topography of the lava flows, modified slightly by frost action and by the addition of a thick mantle of windblown silt but virtually untouched by stream erosion. Many small cinder cones are scattered over the lowlands. The Lost Jim lava flow, a young rugged basaltic lava flow, unmodified by. weathering or erosion, extends from the south shore of. Imuruk Lake nearly to the Kuzitrin flats (pl. 1).

All the major streams that drain the Imuruk Lake area head within the lava plateau. The northward-flowing streams leave the plateau through canyons several hundred feet deep, but the streams that flow southward to the Bering Sea leave in open valleys with gentle gradients. Drainage divides within the lava plateau generally are low and commonly consist of marshes that drain in two or more directions. Surface streams are lacking on the younger lava flows, and drainage is poorly integrated on the older flows. Many surface streams terminate in thaw. sinks (Hopkins, 1949) or disappear beneath the younger lava flows.

Lakes and ponds are abundant. Many occupy initial low areas in the volcanic topography; the others are thaw lakes (Hopkins, 1949): All except Kuzitrin Lake-which may be as deep as 20 feet-are shallow and flat bottomed. The average depth of Imuruk Lake is $71 / 2$ feet, and the maximum depth, 10 feet; other lakes are generally less than 6 feet deep.

\section{BENDELEBEN MOUNTAINS}

The Bendeleben Mountains are an arcuate range extending from the north end of the Darby Mountains 50 miles westward to the Kuzitrin River; the range averages 15 miles in north-south width. The drainage divide lies at or near the north front of the range; thus the mountains consist of a crescentic ridge along the north and northwest margins, from which long straight ridges extend southward to the upper Fish River lowland. The ridges have broadly rolling, generally accordant summit flats, a few hundred to a few thousand feet wide (fig. 3), that probably represent remnants of an uplifted and dissected erosion surface. Steep-sided rock monuments, or tors (Linton, 1949), are scattered along the crests. 


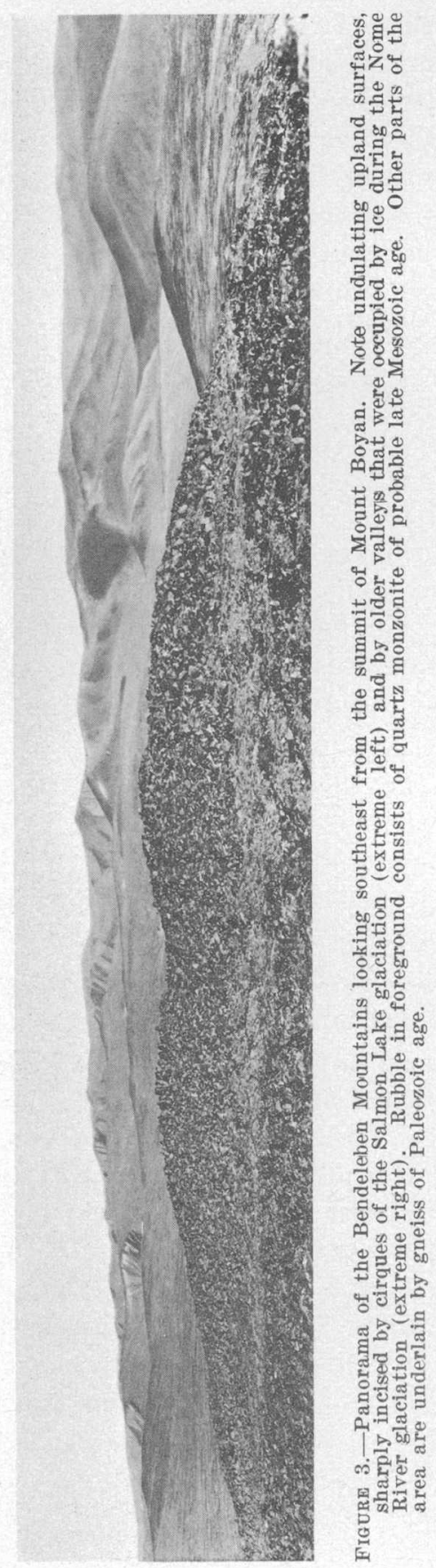


Braided streams flow through long steep-walled valleys into the upper Fish River lowland, and through short valleys to the Kuzitrin and Koyuk Rivers. Fresh cirques and freshly glaciated valleys in the northern part of the range were occupied by ice during late glacial stages, but valleys throughout the mountains contained ice during early glacial stages.

\section{KUZITRIN FLATS}

The Kuzitrin flats are a poorly drained lowland about 24 miles long, 15 miles wide, and in most places less than 200 feet in altitude. The central part is a monotonous plain in which the most conspicuous relief features are pingos, hillocks cored with ice (Porsild, 1938), 20 to 50 feet high. About 20 percent of the surface consists of lakes, and most of the remaining area is composed of the swampy basins of former lakes. The Kuzitrin River crosses from northeast to southwest in a tortuous course incised only a few feet into the surface of the flats. The Noxapaga and the Kougarok Rivers, as well as several smaller streams, join the Kuzitrin River within the flats.

The flats are surrounded on all sides by higher areas. The northeastern part slopes gently upward into the Imuruk Lake lava plateau. The eastern and southern parts are alternating glacial outwash fans and pedimentlike slopes rising to the Bendeleben Mountains. The pedimentlike slopes may represent the same deformed erosion surface that is preserved along ridge crests in the mountains (fig. 3). On the west, foothills of gravel rise to the Seward Peninsula uplands.

\section{SEWARD PENINSULA UPLANDS}

The Seward Peninsula uplands fringe the Imuruk Lake area on the east, north, and west. The uplands consist of a broadly rolling highland surface, evidently an old erosion surface (Hopkins, Karlstrom, and others, 1955, pl. 30), ranging in altitude from 1,000 to 1,800 feet and interrupted at intervals of 1 to 5 miles by steepsided stream valleys incised 200 to 600 feet. Rock monuments are common on the hill crests. The dominant topographic feature is a ridge, extending northwest from the Asses Ears to Crossfox Butte, on which the peaks reach altitudes of 1,700 to 2,073 feet.

Most stream valleys are sharply V-shaped; dissected lava flows form escarpments high on the walls of several valleys. The upper courses of most streams are swift and precipitous, and flood plains are narrow or lacking. The headward parts of many streams are dry most of the year, and segments of streams underlain by metalimestone bedrock generally are dry except during flood stages.

$6806110-63-2$ 
Extensive flood-plain icings (Hopkins, Karlstrom, and others, 1955, p. 114, 141) are common; the lower parts of valley walls adjacent to these icings are distinctly convex, and bedrock is exposed at the margins of the flat gravelly valley bottoms. The lower parts of the trunk streams flow in meandering courses over flood plains as much as 1,000 feet wide. In some places the margins of the flood plains merge with sweeping concavo-convex slopes : underlain by stratified silt and peat on the lower valley walls; in others, the flood plains meet the valley walls in extensive spring-sap escarpments 5 to 20 feet high.

\section{REGIONAL GEOLOGY}

A. H. Brooks (quoted in Cathcart, 1922, p. 166-167) summarized the geology of Seward Peninsula as follows:

The bedrock of Seward Peninsula includes many sedimentary formations, ranging in age from pre-Ordovician to Middle Carboniferous (Pennslvanian). There are also some Upper Cretaceous sediments, 2 as well as extensive lava sheets, chiefly of Quaternary age but in part possibly older, in the eastern part of the peninsula. In much the larger part of the peninsula intrusive rocks are not abundant, but in the Kigluaik, Bendeleben, and Darby Mountains there are extensive stocks of granitic rocks with some dikes. There are also a number of granitic stocks, with which porphyry dikes are associated, in the York district. A few isolated stocks of granite occur in other parts of the peninsula. There are also local occurrences of pegmatitic, gabbroid, and diabasic intrusives.

All investigators of this field have recognized two distinct systems of structure, one trending about north and the other about east, but there is diversity of opinion as to which is the older. The Cretaceous rocks of the eastern part of the field are involved in the northerly folds. As these are the youngest consolidated rocks, it is evident that their deformation occurred during the most recent period of crustal disturbance. There is, however, some evidence of folding in late Paleozoic time, which produced structures trending north. It is therefore possible that the post-Cretaceous (Eocene?) folds followed the structure of older Paleozoic time. The east-west folding is probably to be correlated with the dominating structural features of the Arctic Mountain system of northern Alaska and Siberia, which trend approximately east. This folding was certainly not later than Upper Cretaceous, probably nre-Cretaceous, and certainly not earlier than Middle Jurassic. There is evidence that there has also been some later movements along these east-west folds $* * *$.

The bedrock of most of the gold-bearing areas of Seward Peninsula, especially in its southern part, consists of feldspathic and mica schists locally interbedded with metamorphic limestones that in places broaden out into considerable belts. The schist areas are also in places broken by wide belts of both massive and schistose greenstones and also by narrower belts of slates

\footnotetext{
2 Recent geologic mapping by J. T. Cass (1959) and W. W. Patton (U.S. Geol. Survey, 1961, p. 40-42) has shown that these sediments are mostly of late Early Cretaceous (Albian) age and that volcanic rocks of Late Jurassic and Early Cretaceous age also are widely distributed on eastern Seward Peninsula.
} 
and quartzites. These formations are without doubt Paleozoic, and there is much evidence that they are younger than Silurian. They may be tentatively assigned to the Devonian or Carboniferous.

\section{PALEOZOIC AND MESOZOIC ROCKS}

The basement rocks of the Imuruk Lake area (pl. 1) consist chiefly of folded green schist and metalimestone ${ }^{3}$ of Paleozoic age. A body of quartz monzonite of batholithic proportions and of probable Mesozoic age extends northward across the eastern part of the area from Mount Boyan to the Asses Ears. The batholith is adjoined south of Kuzitrin Lake by an aureole of high-grade gneiss cut by many discordant bodies of granitic rock. The margins of the batholith are buried beneath lava flows of Quaternary age northward from the Kuzitrin and Koyuk Rivers to Imuruk Lake; north of Imuruk Lake, the contact aureole of intense metamorphism is narrower and less pronounced.

Good exposures of the pre-Cenozoic rocks are scarce in the Imuruk Lake area. Lava flows of late Cenozoic age cover more than half of the region, and exposures of pre-Cenozoic rocks are limited to the margins of the lava plateau, to a few deep canyons in the lava plateau that have been excavated through and below the lava flows, and to a few hills within the lava plateau that were not covered by the late Cenozoic flows. A thick mantle of windblown silt covers most gently sloping surfaces, and consequently the character of the bedrock cannot be determined with certainty in many large areas. In areas where the Cenozoic lava flows are lacking and the cover of windblown silt is thin, the basement rocks have been so thoroughly brecciated by frost action that solid-rock outcrops are scarce, although loose blocks pried from bedrock are abundant.

Field observations in 1947 and 1948 cast doubt on the validity of the Paleozoic stratigraphy adopted in northern Seward Peninsula by previous workers (Moffit, 1905, p. 23-24; Collier and others, 1908, p. 65-83). My data are not adequate, however, to establish a new stratigraphy. Consequently, lithologic rather than stratigraphic subdivisions of the metamorphic rocks are shown on plate 1 .

\section{SCHIST UNIT}

Schist of various types is the most widespread metamorphic rock in the Imuruk Lake area. The schist unit is thick, and its lithology is varied; it probably includes rocks younger than, older than,

3 I have adopted Brooks' (1954) suggestion that the term "metallmestone" be applied to metamorphosed rocks composed dominantly of calcite and that "marble" be reserved as a commercial term designating carbonate rock suitable for use as dimension stone. 
and equivalent in age to the metalimestone and gneiss units. Detailed mapping would result in the recognition of several distinct lithologic and stratigraphic units within the area mapped as schist.

Calcite-muscovite schist, quartz-graphite schist, muscovite-graphite schist, muscovite schist, and quartz-biotite schist are the most common types in the area mapped. Thin beds of dark-gray or bluegray metalimestone are common throughout the section.

The grade of metamorphism varies little over the several hundred square miles in which the schist is exposed. The fine texture of the schist and the wide distribution of the calcite-albite-muscovite association place most of the schist among the least metamorphosed rocks in Eskola's green-schist facies (Turner, 1948, p. 96-97).

LITHOLOGY

CALCITE-MUSCOVITE SCHIST

Calcite-muscovite schist predominates near Lava Lake and along the Noxapaga River and is abundant in other parts of the area. The rock, lustrous and light blue gray on fresh surfaces, weathers to dusky yellow. Color terminology followed is that of the "Rockcolor Chart" (Goddard and others, 1948). The closely spaced cleavage imparts a shaly appearance to weathered outcrops. The schist consists of $1 / 8^{-}$to 6 -inch beds. of calcite and muscovite alternating with $1 / 4$ - to 2 -inch beds of pure calcite. . Beds of massive bluishgray metalimestone, a few feet thick, commonly are interbedded with the schist. Near the axes of drag folds the thinner metalimestone beds show a miniature boudinage structure; the original continuity of the beds has been destroyed, and they have been stretched into short augenlike lenses, 1 to 2 inches long and $1 / 2$ to 1 inch thick. Quartz and calcite veins are abundant in fractures in the schist.

Petrographic examination of the schist.indicates that fine-grained calcite constitutes about 50 percent of the schist laminae and that the remainder consists of small grains of muscovite, albite, and ankerite, named in order of decreasing abundance. Some specimens contain traces of zircon. Individual mineral grains range from 0.01 to 0.05 inch in longest dimension.

\section{GRAPHITIC SCHIST}

Graphite is a characteristic component of many metamorphic rocks throughout Seward Peninsula. In a few places in the Kigluaik Mountains the high graphite content of the. schist has encouraged attempts at commercial exploitation (Harrington, 1919a). Graphite-rich rocks, including muscovite-graphite schist and quartzgraphite schist, are common among the schists of the Imuruk Lake area. The graphitic rocks are especially prominent in the canyon of Cottonwood Creek above Divide Creek. Traces of graphite are 
present in other rocks, and graphite crystals as much as an inch in diameter are common in quartz veins.

Muscovite-graphite schist generally occurs in beds, a few feet to a few tens of feet thick, interbedded with calcite-muscovite schist. The muscovite-graphite schist is a fine-grained finely foliated rock, lustrous medium dark gray on fresh surfaces and sooty dark gray in weathered exposures. Graphite makes up 15 to 50 percent of the rock, and the rest consists of muscovite, quartz, and albite. Individual mineral grains can be distinguished with difficulty under the hand lens. The closely spaced cleavage gives a slaty appearance to weathered outcrops.

Quartz-graphite schist occurs in zones, several tens to several hundreds of feet thick, in which nongraphitic rocks are lacking. The schist is medium dark gray on fresh surfaces and nearly black when weathered. In some exposures the rocks break into thin slaty slabs; in others the foliation and bedding are indistinct and the rock breaks along closely spaced intersecting fractures into lathshaped fragments, rhombohedral in cross section. Tabular lenses of calcite, a half inch in diameter, are disseminated through the schist at many localities. Graphite constitutes about 50 percent of the quartz-graphite schist, and quartz and albite make up the remainder of the rock. Some specimens contain a few grains of muscovite.

\section{OTHER ROCKS}

Muscovite or sericite schist is common throughout the Imuruk Lake area. The schist is lustrous light gray and finely foliated, and individual laminae are tightly crinkled. The muscovite schist was not examined petrographically. Field examination indicates that fine shreds of muscovite constitute most of the rock. Talc, graphite, and calcite can be recognized in many specimens.

Beds of quartz-biotite schist, a few feet to a few tens of feet thick, are interbedded with the calcareous and graphitic schist. The quartz-biotite schist is medium to dark gray on fresh surfaces and gray to rusty yellow in weathered exposures. In most localities the schist is fine grained and foliation is obscure.

Chlorite-calcite schist and quartz-calcite schist are present in many localities. Moffit $(1905$, p. 20$)$ reports quartzite beds among the metamorphic rocks exposed along the Pinnell River.

\section{AGE}

No fossils have been found in the pre-Cenozoic rocks in the Imuruk Lake area. However, the lithologic types represented in the schist unit are widespread on Seward Peninsula and are generally 
considered to be of Paleozoic age (Cathcart, 1922, p. 166-168); no metamorphic rocks are present that resemble the andesite of middle Mesozoic age of eastern Seward Peninsula. Metalimestone north of the lava plateau appears on aerial photographs to be traceable eastward into limestone at. Harris Creek and northward to limestone at Cape Deceit from which Kindle (1911) collected Devonian fossils, and another metalimestone belt in the Bendeleben Mountains south of the Imuruk Lake area appears to be traceable westward into the Port Clarence limestone of the York Mountains from which Kindle (1911) collected fossils of Ordovician and Early Silurian age. The rocks of the schist unit thus seem to be mostly of middle Paleozoic age.

\section{METALIMESTONE UNIT}

Massive metalimestone occurs in broad belts of diverse trend in north-central Seward Peninsula. The most extensive metalimestone belt within the Imuruk Lake area underlies the ridge northwest of the Asses Ears. Minor belts trend northward through the confluence of.Andesite Creek and the Noxapaga River and northward across the ridge southeast of Kuzitrin Lake. Metalimestone underlies most of the highest hills in the area and forms outcrops more commonly than any other rock of pre-Quaternary age.

\section{LITHOLOGY}

The metalimestone in broad belts is generally light gray, contrasting sharply with the darker gray and blue-gray tones of metalimestone interbedded with schist and mapped with the scihst unit. Grain size varies widely; individual calcite grains range from 0.01 to 0.3 inch in largest dimension. The metalimestone generally is pure, but in a few localities thin laminae of chlorite and muscovite are present. Rosettes of tremolite are disseminated in metalimestone near contacts with quartz monzonite and at a few other localities. Moffit (1905, p. 22) reports black graphitic metalimestone in the Inmachuk and Goodhope region.

Neither bedding nor cleavage can be discerned in most outcrops of the massive metalimestone, but micaceous impurities impart a vague foliation in a few exposures. Hilltops underlain by metalimestone, however, display on aerial photographs a color banding that evidently reflects bedding. The metalimestone is closely jointed, and fragments rived from the outcrop by frost range from 6 to 24 inches in largest dimension. The frost-rived blocks disintegrate rapidly to platy fragments $1 / 8^{-}$to $1 / 2^{-i n c h}$ thick and $1 / 2$ inch to 4 inches in diameter. 


\section{AGE}

Rocks of the schist. unit lie stratigraphically above and below metalimestone, and therefore the age range of the schist encompasses the age range of at least part of the metalimestone. Moreover, several distinct layers of metalimestone separated by schist may be included in the metalimestone unit, as shown in plate 1. The metalimestone belt north of Cottonwood Creek and the Asses Ears appears to be traceable eastward into limestone at Harris Creek and northward into limestone at Cape Deceit from which Kindle (1911) collected fossils of Devonian age. Like all other bodies of calcareous metasediments on Seward Peninsula (Kindle, 1911; Cathcart, 1922, p. 166-168), all the metalimestone of the Imuruk Lake area is believed to be of Paleozoic age.

\section{GNEISS UNIT}

Gneissic rocks, which probably represent highly metamorphosed sediments equivalent in age to part of the schist unit, form a metamorphic aureole around the Kuzitrin Lake batholith wherever the contact between the batholith and Paleozoic noncalcareous rocks is exposed. Southeast of Kuzitrin Lake, the gneiss belt is 4 miles wide; in the northern part of this belt the metamorphism was extremely intense; less intensely metamorphosed rocks farther from the batholith grade southward into a belt of calcite-quartz-muscovite schist and thin-bedded metalimestone that lies south of the mapped area and extends to the south front of the Bendeleben Mountains. The metamorphic aureole is covered with lava flows of Pleistocene age between Kuzitrin Lake and Imuruk Lake; north of Imuruk Lake the aureole seems to be narrower and the rocks less intensely metamorphosed.

\section{LITHOLOGY}

The gneiss belt south of Kuzitrin Lake consists chiefly of coarsegrained hornblende-microcline gneiss and fine-grained biotite-hornblende-epidote gneiss, but it also contains thin beds of schist and metalimestone similar to rocks included elsewhere in the schist unit and masses of granitoid rocks barely distinguishable from the quartz monzonite of the adjoining batholith. The gneiss unit north of Imuruk Lake consists chiefly of quartz-biotite schist, but includes biotite-oligoclase-diopside gneiss, coarse-grained amphibole-talc schist, diopside granulite, and scapolite skarn. Granite dikes, microclinehornblende-garnet pegmatites, and ptygmatic quartz veins are common throughout the gneiss belt south of Kuzitrin Lake but increase in abundance with approach to the batholith. A belt of massive metalimestone, $21 / 2$ miles long and 800 to 1,500 feet wide, curves 
southwestward within the gneiss from a point about 2 miles south of Kuzitrin Lake.

Collier (Collier and others, 1908, p. 66) designates similar rocks the "Kigluaik group" and describes them as follows:

The rocks of this group have been recognized only in the Kigluaik and Bendeleben Mountain areas, and in both ranges they are so intimately associated with intrusions of granite that it has been impossible to differentiate on the geologic map the igneous from the metamorphic.

Collier believed that at least part of the gneiss represents metamorphosed sediments. Moffit (1905, p. 21) interprets similar gneiss at Kiwalik Mountain between the Kugruk. and Kiwalik Rivers (fig. 1) and in the hills south of the upper course of the Kiwalik River as altered granite.

\section{BIOTITE-HORNBIENDE-EPIDOTE GNEISS}

Fine-grained biotite-hornblende-epidote gneiss is common in the southern part of the gneiss belt, south of Kuzitrin Lake and away from the quartz monzonite batholith. The rock is medium dark gray and closely foliated. Foliation is parallel to alternating darkgray and light-gray bands that reflect small variations in the darkmineral content. At some localities the foliation is crinkled or thrown into tight drag folds. Ptygmatic quartz veins and aplite bodies extend parallel to the contorted banding. The rock cleaves with slight difficulty parallel to foliation but breaks with equal readiness along a closely spaced joint system that cuts the foliation at steep angles. No solid outcrops of biotite gneiss were seen; most of the area underlain by the gneiss is covered with blocks $1 / 2$ foot to 2 feet long.

This finer grained gneiss consists of approximately equal quantities of biotite, hornblende, epidote, and microcline-perthite. Quartz, oligoclase $\left(\mathrm{An}_{15}\right)$, and clinozoisite are minor constituents. Traces of zircon and apatite are present. Individual mineral grains range from 0.02 to 0.04 inch in longest dimension.

\section{HORN BLENDE-MICROCLINE GNEISS}

Coarse-grained hornblende-microcline gneiss is present throughout the gneiss belt south of Kuzitrin Lake and predominates in the northern part near the contact with the Kuzitrin Lake batholith. The rock is crudely banded and ranges in color from light gray to light greenish-gray. Banding is expressed by the parallel orientation of large porphyroblasts of microcline and in some exposures by zones alternately rich and poor in hornblende and diopside. Locally, a later banding, expressed by parallel orientation of large green hornblende porphyroblasts, crosses at an angle of about $30^{\circ}$ the banding expressed by orientation of the feldspar (fig. 4). 


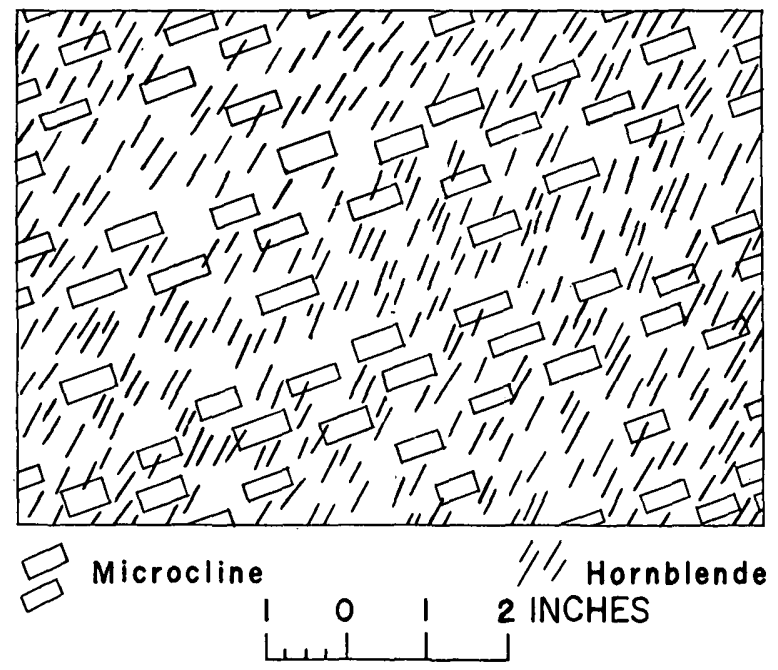

\begin{abstract}
FigdRE 4.-Sketch showing porphyroblasts of hornblende and microcline oriented in divergent directions in coarse-grained hornblendie-microcline gneiss in a nivation cirque 1,800 feet northeast of the summit of Mount Boyan. Horniblende evidently represents a younger foliation superimposed upon older foliation represented by feldspar.
\end{abstract}

The coarse-grained hornblende-microcline gneiss does not break readily parallel to the banding. Instead, the shape of talus and rubble blocks is determined by joints. Outcrops are scarce, and the area underlain by gneiss is largely mantled by frost-rived joint blocks $1 \frac{1}{2}$ to 6 feet in largest dimension.

The mineral composition of the coarse-grained hornblende-microcline gneiss varies widely, but hornblende and microcline are always major constituents. The microcline perthite occurs in tabular porphyroblasts, $1 / 4$ to 1 inch in largest dimension. In some specimens these porphyroblasts constitute as much as 40 percent of the rock. Under the microscope the porphyroblasts are ragged in outline and display well-developed sieve structure. Most of the microcline grains appear to have replaced plagioclase.

Plagioclase is more abundant and more calcic than in the finegrained biotite-hornblende-epidote gneiss, approaching the composition of that in the granite. The plagioclase constitutes 10 to 35 percent of the rock and lies well within the oligoclase range, with an anorthite content of 20 to 22 percent.

The dark minerals consist of hornblende and a moderately pleochroic pyroxene, probably ferroaugite. The hornblende occurs as stubby crystals 0.02 to 0.2 inch long. Most of the hornblende has replaced pyroxene, as is indicated by shreds of pyroxene at the cores 
of many grains. Biotite and quartz are scarce. Sphene, zircon, allanite, and apatite are exceptionally abundant.

\section{OTHER ROCKS}

Biotite-schist, quartz-albite-biotite gneiss, and beds of intensely altered metalimestone are present locally. The biotite schist is a darkgray closely foliated rock that cleaves readily along the foliation planes. The quartz-albite-biotite gneiss is a light-gray granitelike rock that contains discontinuous bands of biotite, a quarter of an inch thick, spaced at intervals of 1 or 2 inches. Impure metalimestone south of Kuzitrin Lake is white and coarse grained and contains quartz, microcline, and diopside, as well as calcite. Scapolite skarn containing 78 to 85 percent of scapolite and variable quantities of garnet, ankerite, forsterite, zoisite, epidote, graphite, diopside, and tremolite and traces of muscovite and pyrite is exposed in the gneiss belt near the north shore of Imuruk Lake. A specimen of diopside granulite adjoining a pegmatite vein half an inch wide in the same area consists of carbonate, diopside, quartz, and sericite, named in order of decreasing abundance.

Dikes and sills of granite gneiss as much as 20 feet wide are common throughout the gneiss belt south of Kuzitrin Lake. They are especially abundant near the contact with the Kuzitrin Lake batholith, but they are common in association with pegmatites and quartz veins elsewhere within the gneiss unit. The granite gneiss consists of microcline perthite and lesser quantities of quartz, plagioclase, and biotite. Sphene makes up as much as 2 percent by volume; zircon, apatite, and magnetite are present in trace amounts.

The granite gneiss of the dikes and sills approaches the mineral composition of the quartz monzonite of the Kuzitrin Lake batholith more closely than any of the other rocks within the gneiss unit. The quartz monzonite, however, is rather uniform in texture and composition, whereas the granite gneiss varies widely in texture and composition within short distances. Patternless fine-grained and coarse-grained patches grade into one another throughout the dikes. Chilled borders are lacking. The margins generally extend parallel to the foliation in the enclosing rocks on a broad scale but interlock raggedly with the enclosing gneiss on a small scale. Thin undistorted plates of the enclosing rock project as much as 6 inches into the main mass of the dikes. The contacts are microscopically or even megascopically gradational through mixed zones as much as an inch wide. Dilational offsets are commonly, though not invariably, lacking at intersections of the dikes.with distinctive zones in the enclosing rocks. 
Goodspeed (1948, p. 63-67) believes that dikes characterized by these textures and structures originate by replacement. Smith and Eakin (1911, p. 69), describing similar relations in the Darby Mountains, state that in places:

It is evident that the apparent gneissic structure is due to replacement of adjacent schists, some of which are so thoroughly saturated by the igneous rocks that much of their original character has been destroyed.

Tabular masses of pegmatite, 0.2 foot to 10 feet thick, are common in the gneiss near the contact with the batholith and among concentrations of dikes and sills in other parts of the gneiss belt. Microcline, quartz, augite, hornblende, and a honey-yellow garnet are conspicuous components of the pegmatites. Many show a distinct textural and mineralogical zonation (fig. 5). The composition

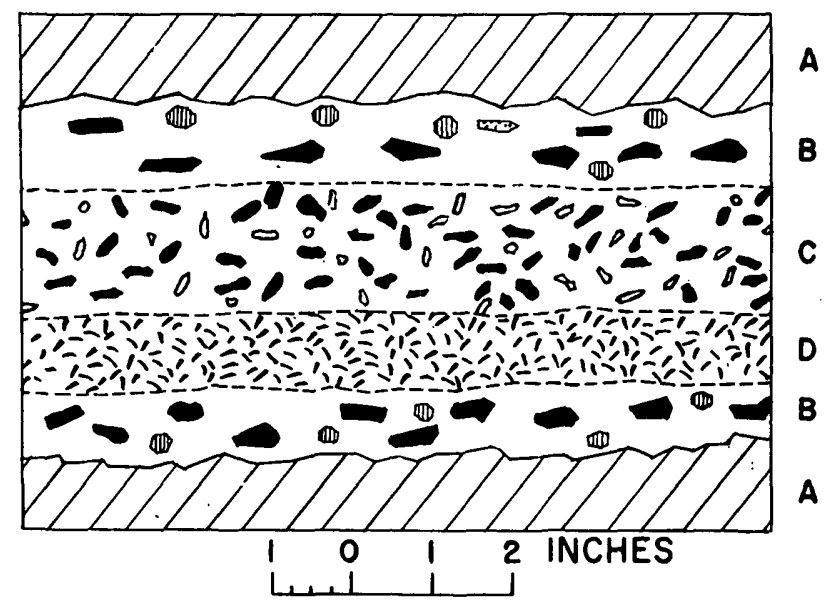

Figure 5.-Sketch of a compound pegmatite dike in the nivation niche 1,800 feet northeast of summit of Mount Boyan. ( $A)$ Coarse-grained hornblende-microcline gneiss (crosshatches indicate orientation of follation in gnelss); $(B)$ coarse-grained microcline, hornblende, pyroxene and honey-yellow garnet; $(C)$ fine-grained microcline, hornblende, and very sparse quartz; $(D)$ very fine-grained intergrowth of microcline and quartz.

of the pegmatite masses commonly varies with the composition of the host rock. The fact that gradational boundaries are common suggests many of the pegmatite masses originated by replacement of the gneiss. Local dilational displacements and disoriented inclusions of gneiss indicate, however, that at least some of these bodies were injected as viscous fluids.

\section{GRADE OF METAMORPHYMM}

' Turner (1948, p. 78-86) considers the assemblage hornblendebiotite-epidote-oligoclase-microcline-quartz (my biotite-hornblendeepidote gneiss) to be a potassium-rich phase of the sillimanite- 
almandine subfacies of Eskola's amphibolite facies and considers the assemblage diopside-hornblende-plagioclase-microcline-quartz (my hornblende-microcline gneiss) to be a potassium-rich phase of the cordierite-anthophyllite subfacies. The predominance of these assemblages throughout the gneiss belt indicates that most rocks of this unit should be assigned to amphibolite facies. The higher calcium content of the feldspars, the coarser grain, and the more thorough obliteration of original sedimentary structure suggest that zones in which the hornblende-microcline gneiss is concentrated represent a somewhat higher grade of metamorphism than those in which biotite-hornblende-epidote gneiss predominates.

The grade of metamorphism in the gneiss increases with approach to the margin of the Kuzitrin Lake batholith, and it seems probable that the gneiss acquired much of its present texture and mineralogy during the emplacement of the batholith. The discordant bodies of granite gneiss and pegmatite seem to have: originated chiefly by metasomatic replacement of the metasediments along closely spaced fractures adjacent to and possibly related to the Kuzitrin Lake batholith, although a few of them may have crystallized from a silicate melt.

Well-defined layers of metalimestone and biotite schist indicate that the gneiss unit includes metamorphosed sediments. Gneiss north of Cloud Lake apparently underlies massive metalimestone; and farther west, in the canyon of Cottonwood Creek, rocks of the schist unit lie in the same stratigraphic position. The gneiss unit evidently includes rocks equivalent in age to some of those included in the schist unit; the gneiss unit is thus considered to consist of metamorphosed sediments of Paleozoic age.

\section{GRANITIC PLUTONS}

Granitic rocks are exposed in nearly all the areas between Kuzitrin Lake and the Asses Ears that are not covered by sediments and volcanic rocks of late Cenozoic age (pl. 1); these exposures probably represent parts of a single pluton, here named the Kuzitrin Lake batholith, extending 27 miles northward from the northern flanks of the Bendeleben Mountains to the Asses Ears. Black Butte is also underlain by a small pluton of granitic rocks, here named the Black Butte stock, surrounded by metalimestone.

Although outcrops of solid bedrock are not common, granite outcrops are more abundant than any of the other pre-Quaternary rocks except metalimestone. The granitic rocks break along widely spaced joints into blocks 1 to 10 feet in diameter. Surfaces underlain by 
granite generally are mantled by frost-rived rubble of angular joint blocks (foreground, fig. 3) interrupted here and there by cathedrallike tors.

\section{LITHOLOGY}

The granitic rocks of the Kuzitrin Lake batholith and the Black Butte stock are light gray, massive or vaguely foliated, and coarsely porphyritic. Large microcline phenocrysts are prominent in nearly every exposure, reaching lengths of $21 / 2$ to 3 inches in the Black Butte stock (Moffit, 1905, p. 28). Planar or linear structures, where observed, are due to parallel orientation of the dark minerals. A few rounded, reworked inclusions were noted at the Asses Ears and in exposures near Kuzitrin Lake. Shadowy inclusions increase in abundance south of Kuzitrin Lake and make up as much as 30 percent of the total volume within a few hundred feet of the south edge of the batholith. Small aplite and pegmatite dikes are present but not common within the main mass of the granitic rocks; however, they are abundant beyond the margin of the batholith in the gneiss unit south of Kuzitrin Lake.

Quartz monzonite predominates, but the granitic rocks range in composition from granite to quartz diorite. Microcline is the dominant feldspar; oligoclase with an anorthite content of 26 to 28 percent is abundant. Quartz is also abundant and generally is visible in hand specimens. The dark minerals are biotite, hornblende, and augite; biotite predominates in most places, but hornblende predominates along the northeast shore of Imuruk Lake. Sphene is extremely abundant in nearly all exposures, constituting an estimated 1 to 3 percent of the total volume. Apatite and magnetite (or ilmenite) are universally present, and zircon and allanite are recognized locally.

The one aplite examined petrographically consists of equal quantities of quartz and microcline and a smaller quantity of oligoclase $\left(\mathrm{An}_{22}\right)$. It contains no dark minerals.

Reworked inclusions in the quartz monzonite range in composition from fine-grained diorite to coarse-grained quartz monzonite that differs from the host rock only in a slightly higher darkmineral content.

\section{CONTACT RELATIONSHTPS}

The contacts between the Kuzitrin Lake batholith and the enclosing metamorphic rocks are buried in most places beneath sediments and lava flows of late Cenozoic age; relatively good exposures are found only south of Kuzitrin Lake. Farther to the south the gneiss belt seems to represent a contact zone several miles wide. 
in which roeks originally similar to those of the schist and metalimestone units have undergone extensive alteration during the emplacement of the quartz monzonite batholith.

The transition from gneiss to quartz monzonite is gradational, occurring in an area about 1,000 feet wide. The transition does not represent, however, an uninterrupted change in the character of the gneiss. Instead, it represents a series of small abrupt changes in the compositions and textures of successive blocks of gneiss, each of which is separated from its neighbors by zones, half a foot to 20 feet wide, of granite; aplite, pegmatite, or quartz. Coarsegrained hornblende-microcline gneiss cut by scattered dikes and veins predominates at the outer margin of the contact zone. Toward the batholith, discordant bodies become more abundant, and within a hundred feet of the contact, as mapped on plate 1 , dikes and veins constitute from $1 / 3$ to $2 / 3$ of the total volume of the rock. Successive blocks of gneiss between the dikes are more and more granitic in appearance as the quantity of hornblende decreases and quartz increases. The foliation gradually fades but still may be represented in vague planar or linear structures seen in granite near the contact.

The metalimestone zone 2 miles south of the east end of Kuzitrin Lake (pl. 1) terminates toward the batholith in somewhat similar fashion. At the north end the metalimestone zone is enclosed in fine-grained granite gneiss. Relicts of metalimestone constitute about 30 percent of the rock. Pegmatite and aplite bodies ranging in width from $1 / 10$ foot to 2 feet cut the granite gneiss and metalimestone, forming an "intrusion" breccia.

The boundaries of the Black Butte stock are relatively well exposed and are sharply defined. No gradational transition zone into the enclosing limestone zone is recognized, although the enclosing metalimestone is altered locally to tremolite schist.

\section{ORIGIN}

The level of thermal energy represented by the Black Butte stock and by the Kuzitrin Lake batholith with its aureole of intensely metamorphosed gneiss is plainly out of harmony with the level of thermal energy represented by the low-grade schist that composes most of the basement rocks of north-central Seward Peninsula. Walton (1955) points out that mobile magmas are the vehicles most capable of transporting heat energy upward through the earth's crust in the large but localized quantities required to explain these relationships. It is reasonable to assume, therefore, that the Kuzitrin Lake batholith: and the Black Butte stock are largely magmatic in origin. 
The detailed field relations suggest, however, that the southern marginal parts of the Kuzitrin Lake batholith may have originated chiefly by further metasomatism of the gneiss. The mineralogical and textural changes accompanying an increase in metamorphic grade in the gneiss with approach to the south margin of the batholith reflect an approach to the bulk composition of the quartz monzonite and suggest that the metasediments of the gneiss unit have undergone extensive metasomatism by fluids associated with the emplacement of the batholith. Evidence already has been presented suggesting that most of the discordant bodies of granite gneiss and pegmatite within the gneiss belt originated by more intense localized replacement. The abundance of shadowy inclusions and poorly defined planar and linear structures in the southern marginal part of the batholith suggest that the quartz monzonite there is the product of still more intense and more thorough metasomatism.

Because of lack of exposures, the character and origin of other marginal parts of the Kuzitrin Lake batholith remain indeterminate. Sharp contacts and sparse alteration of the enclosing metalimestone indicate that the Black Butte stock was emplaced as a magma with little accompanying metasomatism.

The grantic rocks and the enclosing gneiss in the Imuruk Lake area are similar in structure, texture, and mineralogy to granitic and gneissic rocks described by Moffit (1905), Smith and Eakin (1911), and Harrington (1919b) throughout northern and eastern Seward Peninsula. These similarities-notably including a universal abundance of sphene-strongly suggest that the granitic rocks of the region are consanguineous.

\section{AGE}

The Kuzitrin Lake batholith truncates folds involving the Paleozoic schist and metalimestone in the northern part of the Imuruk Lake area; and dikes of granitic rock consanguineous with the batholith are found in gneiss, schist, and metalimestone in the Bendeleben Mountains. Granite bodies that probably are consanguineous intrude andesite of Late Jurassic or Early Cretaceous age in the mountains between the Kiwalik and Buckland Rivers (Harrington, 1919b; Gault, Killeen, West, and others, 1953; U.S. Geol. Survey, 1961, p. 40-42), and pebbles representing typical granite of the Darby Mountains are found in the Ungalik conglomerate of late Early Cretaceous' age east of the Tubutulik River (Smith and Eakin, 1911, p. 56; Cass, 1959). The granite bodies of central and eastern Seward Peninsula are probably of Late Jurassic or Early Cretaceous age. 


\section{STRUCTURE}

The scarcity of outcrops and the reconnaissance nature of the mapping permit only the broadest generalizations concerning the structure of the pre-Cenozoic rocks. Folds in the schist and metalimestone and joints in the quartz monzonite and gneiss are the most obvious structural features of the region.

Scattered measurements of dips and strikes, one observation on the attitude of drag folds at Lava Lake, and the sinuous outcrop pattern of the massive-metalimestone belt north of the Imuruk Lake lava plateau indicate that the schist and metalimestone lie in a series of large, tight, asymmetrical, and, locally, overturned folds, whose axial planes strike north-northwest and whose axes plunge northwest.

The folding evidently was accomplished prior to the emplacement of the Kuzitrin Lake batholith and the Black Butte stock, for both of these bodies are discordant to the folds (pl. 1). Moffit $(1905$, p. 22-23) records "that a gradual increase in the intensity of forces producing the folding took place toward the eastern part of the area." This is reflected by steeper dips as one proceeds eastward across the northeastern part of Seward Peninsula.

Moffit (1905, p. 23) states that the major structure of the metamorphic rocks is modified locally by elongate structural domes; granitic rocks are said to occupy the cores of some of the domes. However, my field work fails to confirm the existence of the structural domes in the Imuruk Lake area. Moffit's geologic map (1905, pl. 3) shows the massive metalimestone in isolated elongate outcrops completely surrounded by schist, but my field mapping within the Imuruk Lake area and photogeologic study of adjoining areas indicates that the massive metalimestone is generally in continuous belts. No structural domes were observed in the metalimestone, and the scanty structural data do not indicate that dips are radial in the metamorphic rocks at the periphery of bodies of granitic rocks.

The quartz monzonite and the gneiss are strongly jointed; the orientation of the joints can be measured on the ground only in isolated rock monuments, but joint traces are clearly discernible in aerial photographs of rubble-strewn areas underlain by quartz monzonite or gneiss. Moffit $(1905$, p. 27$)$ reports a coating of blue fluorite on a joint face in the Black Butte stock.

The two conical peaks of the Asses Ears are separated by a mineralized shear zone, 15 feet wide, that strikes a few degrees west of north and dips nearly vertically, parallel to the most prominent set of joints in the. immediate area. Within the shear zone, frag- 
ments of friable granite, impregnated with sulfides.. and heavily stained with manganese or iron oxides, are enclosed by anastomosing veins of aphanitic green material. Microscopic examination reveals that the green veinlets consist of angular fragments of quartz and feldspar in a fine-grained matrix of chlorite. Granite adjacent to the shear zone is exceptionally rich in biotite.

\section{CENOZOIC ROCKS}

Seward Peninsula during most of Tertiary time seems to have lain near the center of a highland area that extended across much of what is now the Bering-Chukchi marine platform (Hopkins, 1959a). No early Tertiary sediments are recognized with certainty on Seward Peninsula, though a small patch of coal-bearing sediments at Coal Creek in the valley of the Sinuk River (fig. 1) may prove to be of early Tertiary age (Collier and others, 1908, p. 83-85). Instead, the Peninsula seems to have undergone longcontinued subaerial erosion that produced, by late Tertiary time, an undulating erosion surface, the "Kugruk plateau" of Collier (1902, p. 35-36), having a relief of a few hundred feet. Extensive remnants of the late Tertiary erosion surface are preserved now on the interfluves in many upland and mountain areas on Seward Peninsula (fig. 3, this report; Hopkins, Karlstrom, and others, 1955 , middleground and background of fig. 30 ).

The formation of the erosion surface seems to have been terminated by an episode of warping that submerged the Bering-Chukchi platform and created several faulted upwarps and troughs on Seward Peninsula ( $\mathrm{pl} .2$ ). Evidence at Nome and elsewhere along the shores of Bering and Chukchi Seas indicates that the present marine basins of northern Bering Sea, Bering Strait, and Chukchi Sea came into existence late in the Pliocene epoch (Hopkins, 1959a). The Kougarok gravel of middle to late Tertiary and possibly early Pleistocene age appears to rest on a part of the ancient erosion surface that has been downwarped to present sea level (Collier and others, 1908, p. 302); thus the ancient erosion surface seems to have been deformed during late Tertiary time. Continued faulting and warping have resulted in the deformation of much younger Pleistocene sediments and marine erosion surfaces in many places on Seward Peninsula.

Pre-Cenozoic bedrock throughout much of Seward Peninsula is mantled now by unconsolidated sediments and, in several large areas, by volcanic rocks of late Cenozoic age. The unconsolidated sediments include glacial till and outwash and windblown silt derived during glacial intervals from outwash plains on Seward 680611 o-63-3 
Peninsula and on the present site of Kotzebue Sound, stratified silt and peat consisting mostly of reworked windblown silt, alluvial gravel, marine sand and gravel, lacustrine sediments, and frostmoved mantle. The glacial history of Seward Peninsula is reviewed briefly in the paragraphs that follow because many of the volcanic rocks and nonglacial sediments in the Imuruk Lake area can be dated on the basis of their stratigraphic relationships with the glacial deposits and the windblown silt.

Glaciers have covered most of Seward Peninsula west of Moses Point, east of Teller, and south of the Kuzitrin and Koyuk Rivers (pl. 3) ; small glaciers also were present in isolated highlands, such as the York Mountains and Midnight Mountain. Deposits of five distinct glaciations are recognized on Seward Peninsula (Hopkins in Pewe and others, 1953). From oldest to youngest these include the Iron Creek glaciation, the Nome River glaciation, the Salmon Lake glaciation, the Mount Osborn glaciation, and an unnamed glacial advance that took place within the last one or two hundred years.

The Iron Creek glaciation is represented by till and outwash buried beneath till and outwash of the Nome River glaciation at the confluence of Iron Creek and the Kruzgamapa River (also known locally as the Pilgrim River). The buried drift was discovered in placer-mine workings in 1908; several stratigraphic sections are given by Smith (1909, p. 317-319). Wood contained in peat that separates the drift of the Iron Creek glaciation from the drift of the Nome River glaciation was identified by F. H. Knowlton as spruce and Douglas-fir (Smith, 1910, p. 108-109). Drift of pre-Illinoian age is also present on the coastal plain at Nome (Hopkins, MacNeil, and Leopold, 1960, fig. 2). The extent of the Iron Creek glaciation elsewhere is unknown. The glaciation is probably of Kansan or, possibly, of Nebraskan age.

The Nome River glaciation is represented by broad smoothly rounded morainal ridges and associated ground moraine and by outwash in the Nome River valley and in and near the mountainous and higher upland areas elsewhere on Seward Peninsula. Stratigraphic relations between glacial, alluvial, and marine sediments in the coastal plain at Nome indicate clearly that the Nome River glaciation is of Illinoian age (Hopkins, MacNeil, and Leopold, 1960).

The Salmon Lake glaciation is represented by rugged end moraines and associated ground moraine and outwash near Salmon Lake and in and near other mountainous areas of Seward Peninsula. Glaciers covered a much smaller area during the Salmon 
Lake glaciation than during the Nome River glaciation. Deposits of the Salmon Lake glaciation probably. represent all subdivisions of the Wisconsin glacial age.

The Mount Osborn glaciation is represented by small sharpcrested. moraines that coincide with the locations of marked changes in the character of the walls in glaciated valleys incised in the slopes of Mount Osborn and in glaciated valleys elsewhere in the higher parts of the Kigluaik, Bendeleben, and Darby Mountains (locations not shown on pl. 3). The Mount Osborn glaciation may have taken place in latest Wisconsin time; about 10,000 or 11,000 years ago; in early Recent time, about 7,000 or 8,000 years ago; or after the postglacial thermal maximum, between 2,000 and 4,000 years ago.

An advance during the last one or two hundred years is represented by a small vegetation-free moraine a few hundred feet in front of a glacier at the head of Grand Union Creek in the Kigluaik Mountains.

The Imuruk Lake lava plateau is one of several fields of basalt of late Cenozoic age on Seward Peninsula (pl. 2) ; similar volcanic fields are widely distributed in central and western Alaska and on the Bering marine platform (Dutro and Payne, 1954). The volcanic rocks on Seward Peninsula have been described briefly by Mendenhall (1902, p. 206), Moffit. (1905, p. 31-35), Smith and Eakin (1911, p. 71-74), Harrington (1919b, p. 377-378, 388-391), and Steidtmann and Cathcart (1922, p. 31, 117).

The volcanic rocks on Seward Peninsula consist of basalt and basaltic andesite lava flows and small agglomerate and cinder cones ranging in age from late Tertiary to Recent. Pyroclastics are scarce, except in an extensive ash-covered area surrounding Devil Mountain. Long-lived central volcanoes are rare; most of the volcanic rocks were emitted from short-lived widely scattered vents. The vents rarely show pronounced alinements, but they do tend to be concentrated in northwestward-trending swarms a few miles wide and a few tens of miles long (pl. 2).

\section{UNCONSOLIDATED SEDIMENTS} KOUGAROK GRAVEL

A sheet of gravel that is partly of middle to late Tertiary age and perhaps partly of early Quaternary age, ${ }^{4}$ here named the Kougarok gravel, occupies a belt, 18 miles long and 1 to 4 miles wide, extending along the northwest margin of the Kuzitrin Flats from Bunker Hill to the valley of the Noxapaga River (fig. 1).

4 In an earlier abstract, W. S. Benninghoff and I mistakenly described this gravel as being entirely of early Pleistocene age and correlated it with the interglacial beds at Iron Creek (Hopkins and Benninghoff, 1953). 
Gravel that may be correlative with some part of the Kougarok gravel underlies lava flows of the Imuruk volcanics in the valley walls of Perry Creek and the Inmachuk River.

\section{STRATIGRAPHY AND LITHOLOGY}

The Kougarok gravel is named for good exposures along and near the lower course of the Kougarok River. The gravel at the type locality was well exposed in the drainage basin of Quartz Creek, a tributary of the lower Kougarok River, during intensive placer-mining in the early 1900's. The following composite section is abstracted from unpublished data and published descriptions (Collier and others, 1908, p. 300-306, 309-314) by A. H. Brooks, who studied the gravel in considerable detail:

$\begin{array}{lc}\text { Thickness (feet) } & \text { Lithology } \\ 15-20 & \text { Frozen organic silt and peat. }\end{array}$

$3-15$

0. $5-2.0$

Fine reddish gravel and sand, lenses of silt and fresh-looking wood; locally gold-bearing at base.

Sticky blue-gray clay or muck; a spruce $\log , 80 \mathrm{ft}$ long and $5 \mathrm{ft}$ in diameter, and an associated horse jaw found in frozen clay in a placer-mine drift on Quartz Creek (Collier, 1902, p. 27) may have come from this stratigraphic unit.

$187+\quad$ Coarse white quartz gravel; base not reached in deep shaft near Dahl Creek, a tributary of Quartz Creek.
Present Interpretation

Windblown silt and colluvium of late Quaternary age.

Upper member of Kougarok gravel; of late Tertiary or early Quaternary age.

Middle member of Kougarok gravel; of late Tertiary age.

Lower member of Kougarok gravel; probably of middle or late Tertiary age.

The Kougarok gravel is distinguished from auriferous gravel of late Quaternary age by its distribution in high terraces and in interfluves between modern streams, by the reddish color of the upper member, and by an exceptionally thick weathered zone in bedrock beneath the base of the formation in some exposures. Gravel of late Quaternary age generally lacks the reddish limonite stain and is found only beneath flood plains and in low terraces along the present streams. The Kougarok gravel is generally better sorted and much thicker than gravel of late Quaternary age in the same area.

In the Imuruk Lake area the Kougarok gravel reaches its maximum thickness along the lower course of Turner Creek (pl. 1), where all three members are present and have a combined thickness exceeding 170 feet. The upper member here consists of gravel more than 60 feet thick, and the middle member consists of lignite, 1 to 12 feet thick, underlain by underclay, 1 or 2 feet thick. A mine shaft at a lignite outcrop 0.3 mile up Turner Creek from the confluence with the Noxapaga River penetrated 100 feet of gravel of the lower member without reaching bedrock (Mr. Jules Gunder- 
son, miner, Nome, oral communication, 1948). The formation is mantled by 20 to 30 feet of peat, windblown silt, and stratified silt throughout most of the area southwest of Grouse Creek.

The Kougarok gravel thins abruptly northward up the Noxapaga River from Turner Creek; the thinning is due to the wedging out of the lower and middle members and to a rise in the level of the bedrock floor beneath the formation. The upper member rests directly on deeply weathered schist or on a weathered lava flow of the Kugruk volcanics in terrace remnants between Grouse and Andesite Creeks. The combined thickness of the gravel and the lava flow ranges from 25 to 45 feet; schist bedrock in the terraces stands 20 to 40 feet above the Noxapaga River.

Schist bedrock and a lava flow of the Kugruk volcanics are weathered to a depth of 15 feet beneath the upper member of the Kougarok gravel in terraces along the Noxapaga River (fig. 6). The musco-

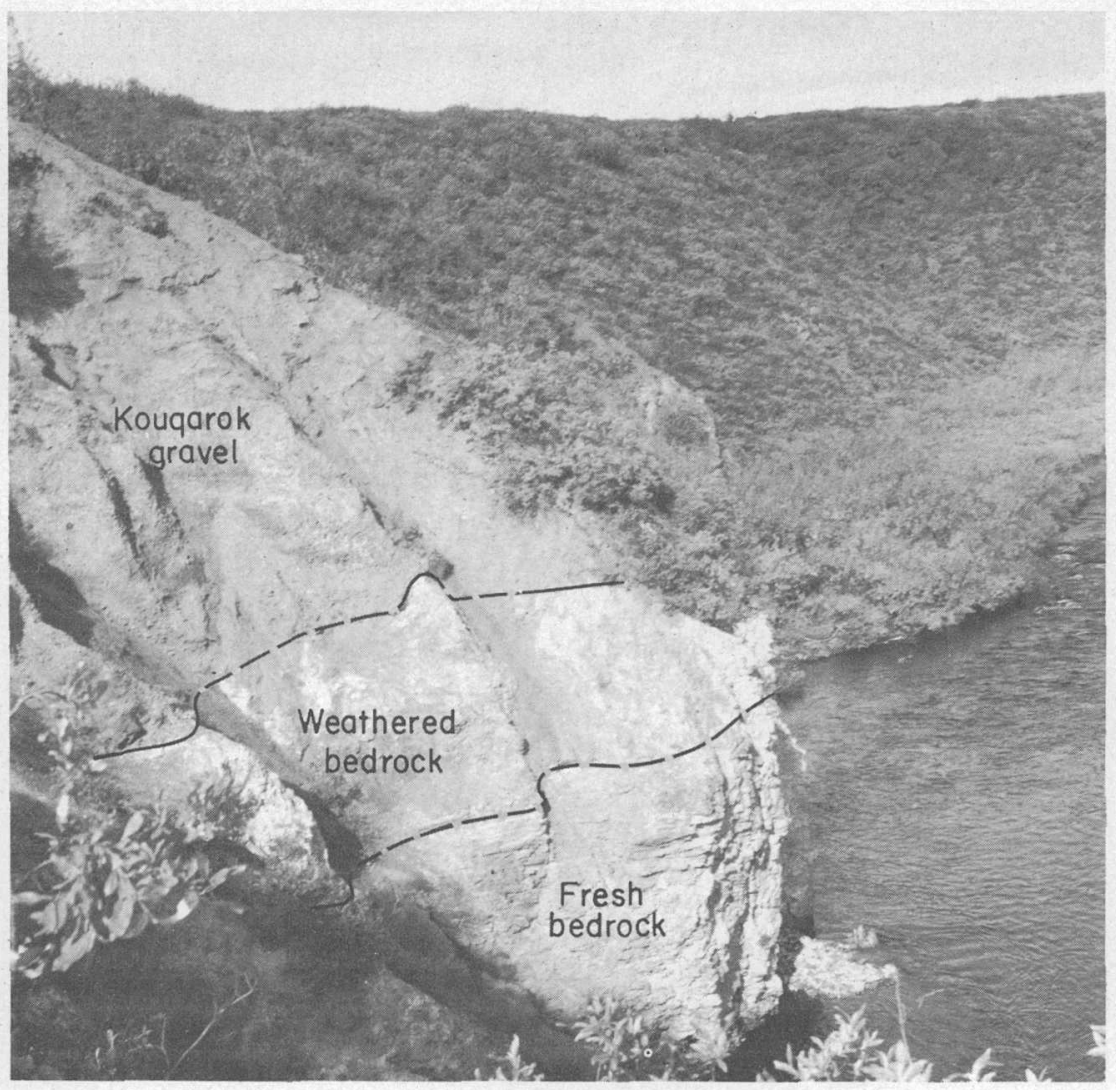

FIGURE 6.-Weathered bedrock beneath Kougarok gravel in terrace on west side of Noxapaga River 0.3 mile upstream from Goose Creek, Unweathered blocky muscovitecalcite-quartz schist at river level grades upward into bedrock, reduced by weathering to structureless quartz-albite sand, and then into Kougarok gravel. Weathered zone is about 15 feet thick. 
vite-calcite-quartz-albite schist bedrock is weathered to friable lightgray quartz-albite sand. Weathered bedrock similar in texture, but characterized by greater abundance of red iron oxides, commonly underlies gravel of late Quaternary age on Seward Peninsula. The weathered zone beneath gravel of late Quaternary age, however, is rarely more than 3 feet thick and generally is considerably thinner.

Gravel that may be equivalent in age to part of the Kougarok gravel is found beneath lava flows assigned to the Imuruk volcanics in the valley walls of the Inmachuk River and at Perry Creek, a tributary of the Pinnell River. The gravel is sparsely auriferous and has been mined for its gold content at Perry Creek, as well as in several places along the lower Inmachuk River north of the map area (pl. 1).

The following stratigraphic section was recorded in underground workings in the area shown on plate 1 as Kougarok gravel at Perry Creek (Henshaw, 1910, p. 368; Mr. Jim Black, prospector, Deering, Alaska, oral communication, 1948) :

\begin{tabular}{|c|c|}
\hline $\begin{array}{l}\text { Thickness (feet) } \\
\text { Unknown } \\
\text { Unknown-...- } \\
25 \\
20 \\
3-9\end{array}$ & \begin{tabular}{l}
\multicolumn{1}{c}{ Lithology } \\
Lava flow at top of bluff. \\
Gravel, barren. \\
Lava flow. \\
Muck, containing small pieces of wood at base. \\
Gravel, auriferous, on schist bedrock.
\end{tabular} \\
\hline
\end{tabular}

Tailings from the underground workings at Perry Creek consist largely of rounded cobbles and boulders, as much as a foot long, composed of mica-schist, graphite schist, metalimestone, a lime-silicate rock, and black dense basalt. A $\log 3$ feet in diameter is reported to have been found at an unspecified place in the Perry Creek mine workings (Henshaw, 1910; Mr. Jim Black, oral communication, 1948).

The Kougarok gravel in the Imuruk Lake area consists chiefly of clean well-sorted, well-rounded reddish-brown pebble-cobble gravel. Thin beds of sand and silt containing well-preserved wood are scattered throughout most exposures. Powdery limonite that permeates the gravel and sand is responsible for the characteristic reddish-brown color; locally the gravel is loosely cemented by the limonite. The gravel and sand are sparsely auriferous, and attempts have been made to mine the formation at several localities. The lignite of the middle member of the Kougarok gravel in the Turner Creek area consists of contorted and compressed fragments of lignified wood in a matrix of soft powdery organic material.

Pebbles, as much as 2 inches long, are common, and 4-inch cobbles are scattered through the gravel exposed along Turner Creek. Beds of 3- to 6-inch cobbles and scattered angular lava boulders, 
as much as $21 / 2$ feet in diameter, are found in exposures in the Noxapaga River valley. Pebbles of mica-schist, graphitic quartzite, vein quartz; and metalimestone occur in equal quantities. Basalt fragments are a major constituent in gravel of the high terraces of the Noxapaga River valley.

\section{FOSSILS AND AGE}

Wood from the upper member of the Kougarok gravel at the type locality on Quartz Creek has been determined by the radiocarbon method to be more than 30,000 years old (sample W-196, Meyer Rubin; written communication, 1955). Wood from the upper member near the junction of Goose Creek and the Noxapaga River was identified as poplar and as either spruce or larch (William Spackman, paleobotanist, Pennsylvania State College, written communication, 1951). Spruce, larch, and probably poplar are represented in the rich pollen assemblage of late Tertiary age found in the middle member of the Kougarok gravel on Turner Creek; thus, the upper member may also be of late Tertiary age. However, the fact that the wood in the upper member is fresh and nonlignified suggests it may be much younger than the lignified wood in the middle member. Spruce, poplar, and probably larch extended far beyond their present western limits during a warm interval 8,000 to 10,000 years ago (Hopkins and Giddings, 1953, p. 2528) and probably during earlier Pleistocene interglacial intervals. The scanty paleobotanical evidence is consistent with the hypothesis that the upper member of the Kougarok gravel may have been deposited during an early Pleistocene interglacial interval.

The middle member of the Kougarok gravel at Turner Creek contains wood of the family Cupressaceae, probably of the genus Thuja (cedar) (E. S. Barghoorn, paleobotanist, Harvard University, written communication, 1951) and a rich pollen flora recording a woodland vegetation that included Picea (spruce), Tsuga (hemlock), Abies (fir), Pinus (pine), Larix (larch), Carya (hickory), Juglans (walnut), Pterocarya (an Old World genus related to hickory), Betula (birch), Alnus (alder), Fagus (beech), Quercus (oak), Ulmus-Zelkova (a grouping that includes elm and a closely related genus. now confined to the Old World), and several groups of shrubs and herbs (W. S. Benninghoff, paleobotanist, University of Michigan, written communication, 1961). The pollen flora in the middle member of the Kougarok gravel resembles a pollen flora contained in sediments from the Aldan River valley, Yakutia, Siberia, that Soviet workers consider to be of late Miocene or early Pliocene age (Fradkina, 1958) and pollen floras contained in the Nenana gravel of the Alaska Range, considered by 
MacNeil, Wolfe, Hopkins, and Miller (1961) to be of middle Miocene or younger age. The pollen flora of the middle member of the Kougarok gravel is much richer and contains many more exotic genera than pollen floras obtained by E. B. Leopold (palynologist, U.S. Geological Survey, written communication, 1961) from the marine sediments of Submarine Beach at Nome, considered by Hopkins, MacNeil, and Leopold (1960) to be of late Pliocene or early Pleistocene age. Therefore, the middle member of the Kougarok gravel is considered to be of late Miocene or early Pliocene age.

No fossils have been found in the lower member of the Kougarok gravel. Because of its stratigraphic position below lignite bearing a late Tertiary flora, the lower member is probably of middle or late Tertiary age.

\section{GLACLAL DRTFT}

NOME RIVER GLACIATION

Glacial deposits of Nome River (Illinoian) age are found in the valleys of Minnie and Caviar Creeks and in a topographic trench extending from Caviar Creek to the east end of Kuzitrin Lake. Those on lower Minnie Creek were observed from the air but were not visited on the ground. They consist of a smooth-sided arcuate gravel ridge extending across the valley at the point where Minnie Creek leaves the Bendeleben Mountains and an extensive mantle of unconsolidated sediments on the valley walls upstream from the morainal ridge. The moraine, though high, lacks characteristic glacial microrelief and is typical of the form of end moraines of the Nome River glaciation in other parts of Seward Peninsula. It is overlain locally by a lava flow of the Gosling volcanics.

The valley slopes of upper Caviar Creek are covered by a thick mantle of gneiss and quartz monzonite blocks in a matrix of silty sand; a similar deposit is found in the pass south of Sturgeon Ridge between Caviar Creek and Kuzitrin Lake. The material bears no characteristic glacial microrelief, but its texture, thickness, and position suggest that it is till of the Nome River glaciation. Quartz monzonite bedrock in the rolling hills between Kuzitrin Lake, Caviar Creek, and the head of the Koyuk River is overlain by a much thinner deposit of similar material. The bedrock lithology is such that erratics, if present, were not recognized; no moraines or other ice-marginal features were seen. The thin rubbly soils, however, contrast sharply with the thick cover of windblown silt that mantles hills of quartz monzonite southwest of Sandy Lake, southwest of Rhododendron Cone, and northeast of Imuruk Lake. It is suggested, therefore, that during the Nome River glaciation ice extended down the valley of Caviar Creek, 
across the hills between Kuzitrin Lake and the head of the Koyuk River, and into the area further north now covered by lava flows of the Gosling volcanics.

\section{SALMON IAKE GLACIATION}

Till of the Salmon Lake glaciation is found only in a shallow north-facing cirque at the head of Caviar Creek. A moraine consisting of two 30 -foot hillocks composed of gneiss rubble confines a small lake near the mouth of the cirque. A narrow terrace downstream from the moraine and a few feet above stream grade is evidently underlain by outwash of Salmon Lake age. Behind the moraine, the east wall of the cirque is a sharply chiseled slope in which gneiss bedrock is locally exposed above steep active talus cones. The topography of the moraine and of the cirque walls is typical of deposits and erosional features in other parts of Seward Peninsula assigned by me to the Salınon Lake glaciation.

\section{WINDBLOWN SILT}

A mantle composed predominantly of silt-sized mineral grains showing little evidence of redistribution by flowing water covers much of the undulating surface of the Imuruk Lake area. I mistakenly stated in 1949 (Hopkins, 1949, p. 121) and implied in 1951 (Hopkins and Sigafoos, 1951, p. 59-60) that this mantle represents the residual product of long-continued frost disintegration of underlying rocks. However, the texture, structure, mineralogy, and distribution of the mantle indicate clearly that the mantle consists mostly of windblown silt, but it commonly contains debris rived by frost from the local bedrock. The windblown silt is not shown as a map unit on plate 1 because it is a general blanket covering nearly all other geologic units.

The deposits include patches of silt a few inches thick perched on the Lost Jim and Camille lava flows, silt filling the interstices of frost-rived rubble in areas underlain by the Gosling volcanics, and continuous silt blankets as much as 20 feet thick on the flows of the Imuruk volcanics and on pre-Quaternary rocks. Deposits that have undergone little reworking by flowing water are largely confined to extensive surfaces of little relief. On slopes steeper than $5^{\circ}$ or $6^{\circ}$ and in creek valleys, the unreworked silt commonly interfingers with or wedges out beneath deposits of stratified organic silt and interbedded peat. The silt is found up to altitudes of about 1,800 feet in areas south of the ridge extending from Virginia Butte to Crossfox Butte; north of the ridge, however, thick silt deposits seem to be limited to areas below 1,500 feet in altitude.

The silt generally is perennially frozen within less than 3 feet of the surface. The frozen silt contains much clear ice in the form of 
large vertical ice wedges arranged in polygons having diameters of several tens of feet and in closely spacèd small lenses making up "ice gneiss" (Taber, 1943, p. 1512, and pl. 17, fig. 1).

Because the silt is distributed chiefly on undulating surfaces away from trunk streams, good exposures of vertical sections are scarce. Sections through the thicker accumulations are found only in the walls of a few thaw sinks. Upon removal of the natural vegetaion, moreover, the silt thaws and the ice melts, releasing quantities of water far in excess of the porosity of compacted silt. The few natural cuts consequently thaw and slump within a few days after they form.

\section{LITHOLOGY}

Frozen silt is light blue gray; thawed silt that has been exposed for a few months is light gray brown. Organic matter is scarce, but masses of peat are incorporated locally. Saturated unfrozen silt is slightly plastic (Hopkins and Sigafoos, 1951, p. 50). Specific gravity ranges generally from 2.40 to 2.51 .

Stratification generally is not perceptible. Deposits on slopes steeper than about $5^{\circ}$, however, may display a crude banding expressed by differences in color, by slight differences in grain size, by lines of incorporated rock fragments, or by lenses of peat. The bands evidently mark successive sheets of silt that have glided downslope by solifluction or cryofluction. Traces of extremely contorted laminations also can be recognized in a few exceptionally good exposures.

The texture of the silt mantle differs slightly at different depths and on rocks of different age or lithology. Surfaces underlain by granite or schist are commonly blanketed by a uniform blue-gray silt in which megascopic rock fragments are scarce or lacking (specimen G, fig. $7 B$ ) ; locally, however, a few chips of the underlying bedrock appear at the surface. Similarly, silt blanketing the older

Explanation OF FIGURE 7
Specimens A, B, and $\mathrm{C}$ collected on Imuruk volcanics, 47Ahp526 on Lost Jim lava flow on Lost Jim Peninsula, 47Ahp528 on Camille lava flow near Camille Cone, $\mathrm{E}$ and $\mathrm{F}$ on Imuruk volcanics, $\mathrm{G}$ on schist, I, J, and $\mathrm{K}$ in terrace at west end of Imuruk Lake, TE at Candle Creek. Included for comparison are TA, "slate" (probably schist) exposed to frost weathering for 1 year at Candle; TK, rock flour from Castner Glacier; and PW, modern windblown silt from Big Delta, Alaska. Cumulative grain-size frequency curves are subdivided into size grades according to unified soils classification of the U.S. Corps of Engineers. Mineralogy of A, B, C, E, F, G, I, J, and $\mathrm{K}$ given in table 1. TA, TK, and TE taken from Taber, (1943, table 1); PW from Péwé (1951, fig. 1). Mechanical analysis of specimen $\mathbf{G}$ by $\mathbf{A}$. T. Fernald; others by Permafrost Branch, St. Paul District, Corps of Engineers, U.S. Army, Fairbanks, Alaska. 

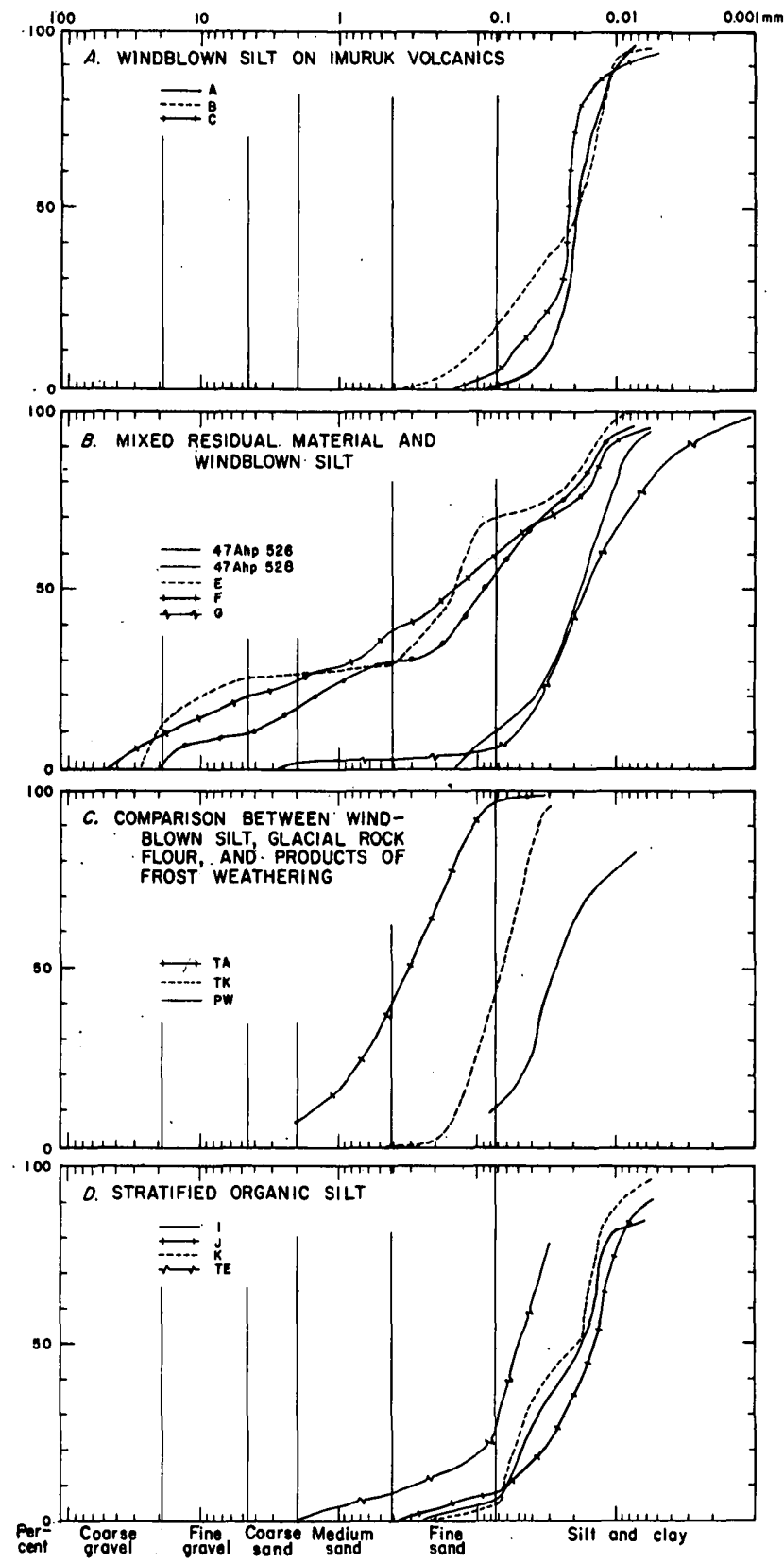

Figura 7.-Mechanical composition of fine-grained mantle in the Imuruk Lake area. 
flows of the Imuruk volcanics contains few or no megascopic fragments of basalt at the surface (specimen $\mathrm{B}$ and $\mathrm{C}$, fig. $7 A$ ). . Sections in the walls of thaw sinks show, however, that at depths of 5 to 10 feet the silt contains scattered blocks of basalt ranging from a few inches to a few feet across. The lava blocks become more abundant with increasing depth until at depths of 10 to 20 feet beneath the surface the mantle consists of angular lava blocks in contact with one another; their interstices are filled with silt. (See Hopkins, 1949, pl: 2 and fig. 5.) Even at this depth, however, the interstitial silt commonly is well sorted (specimen $\mathrm{A}$, fig. $7 A$ ). At still greater depth the silt disappears abruptly, and the mantle consists of clean rubble with open interstices, as seen in the walls of furrows in the floors of some thaw sinks (Hopkins, 1949, p. 128). Fine-grained mantle on the younger lava flows generally contains a larger admixture of residual material resulting in bimodal or multimodal grain-size distributions (specimens E, F, and 47Ahp528, fig. $7 B$ ), but even here a distinct silt peak reflects the presence of foreign material introduced by wind.

Relatively pure deposits of massive silt in the Imuruk Lake area are nearly identical in grain size and sorting with silt collected by Péwé (1951) from eolian deposits currently accumulating near the confluence of the Delta and Tanana Rivers (specimen PW, fig. $7 C$ ); it is slightly finer than rock flour collected by Taber (1943, p. 1477) from a stream issuing from beneath Castner Glacier in the Alaska Range (specimen TK, fig. $7 C$ ) and much finer than disintegration products collected by Taber (1943, p. 1449) on "slate" (probably schist) exposed to frost action for 1 year in a mining cut near Candle (specimen TA, fig. $7 C$ ).

\section{MINERALOGY}

The following discussion is based on mineralogical analyses and amplifying notes prepared by Dorothy Carroll, U.S. Geological Survey. The specimens upon which the descriptions are based were washed free of clay; the remaining material was dried and then separated in bromoform. The minerals in the light and heavy fractions were identified microscopically, with the exception of magnetite, which was removed with a small magnet.

The mineral composition of the silt mantle is largely independent of the underlying bedrock. All the specimens that have been examined mineralogically (columns A-H, table 1), including specimens collected in both basaltic and schist terranes, contain minerals that must have been derived from basalt (calcic feldspar, augite, olivine) together with minerals that must have been derived from schist or granite (quartz, oligoclase, orthoclase, muscovite, diopside, 
glaucophane, another amphibole, zoisite, clinozoisite, tourmaline, sphene, and zircon). Most specimens consist entirely of fine angular mineral grains. A specimen of sandy silt collected among blocks of basalt at the surface of a flow of the Imuruk volcanics, however, contains large fresh grains of augite and large angular grains of calcic plagioclase (column $\mathrm{F}$, table 1) ; specimens of sandy silt collected near. schist bedrock at Lava Lake contain abundant large grains of fresh diopside, zoisite, and clinozoisite (column G, table 1) and much coarse magnetite (column $\mathrm{H}$, table 1 ).

TABLE 1.-Mineral composition of fine-grained silt mantle in the Imuruk Lake area [Identiflcations by Dorothy Carroll, U.S. Geol. Survey. A, abundant; F, fair amount; S, small amount; $\mathrm{S}-$, scarce; + , present in very small amount]

\begin{tabular}{|c|c|c|c|c|c|c|c|c|c|c|c|}
\hline \multicolumn{4}{|c|}{ Windblown silt } & \multicolumn{4}{|c|}{$\begin{array}{l}\text { Mixed residual material } \\
\text { and windblown silt }\end{array}$} & \multicolumn{4}{|c|}{ Stratiffed silt and peat } \\
\hline \multicolumn{4}{|c|}{ On basalt } & \multicolumn{2}{|c|}{ On basalt } & \multicolumn{2}{|c|}{ On schist } & \multicolumn{3}{|c|}{ On basalt } & \multirow{2}{*}{$\frac{\begin{array}{c}\text { On } \\
\text { schist }\end{array}}{L}$} \\
\hline A & B & $\mathrm{C}$ & D & $\mathbf{E}$ & $\mathbf{F}$ & G & H & I & $\mathbf{J}$ & $\mathbf{K}$ & \\
\hline
\end{tabular}

Light fraction

\begin{tabular}{|c|c|c|c|c|c|c|c|c|c|c|c|c|}
\hline ......... & $-\pi$ & s- & $\cdots$ & s- & $\mathrm{s}$ & $\underset{g}{F}$ & $\mathrm{~s}$ & $\underset{s}{\mathbf{F}}$ & $\mathrm{s}$ & \pm & + & F \\
\hline Labradorite to anor- & & & & $8-$ & & $\mathrm{s}$ & & 8 & & & & \\
\hline $\begin{array}{l}\text { thite } \\
\text { Orthoclase }\end{array}$ & $\mathbf{F}$ & $\mathbf{F}$ & F & F & A & $\underset{\mathrm{S}}{\mathrm{F}}$ & $\mathbf{F}$ & -3 & $\mathbf{F}$ & F & $\mathbf{F}$ & $\stackrel{S}{S}$ \\
\hline Muscovit & $\mathrm{F}$ & $\mathrm{s}$ & $\mathbf{F}$ & $\mathbf{F}$ & & + & $\mathrm{F}$ & + & + & T & $\mathrm{F}$ & \\
\hline $\begin{array}{l}\text { Blotite. } \\
\text { Mica } 1 .\end{array}$ & s & $\mathrm{F}$ & $s$ & $\mathrm{~F}$ & $\cdots . .$. & + & $\mathrm{F}$ & $t$ & ..... & F & $\mathrm{F}$ & \\
\hline
\end{tabular}

Heavy fraction

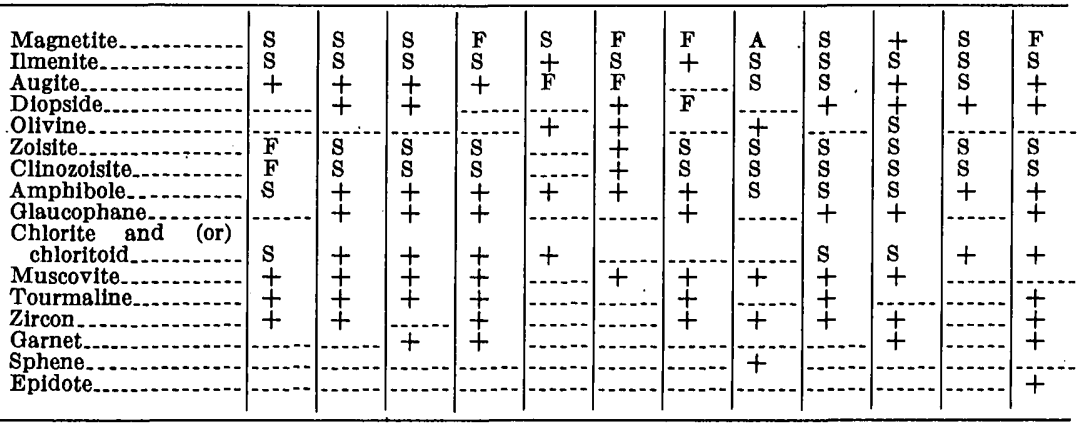

1 Micaceous grains which may be altered biotite, chlorite, or chloritoid. These grains are pale in color and generally contain inclusions.

\section{AGE AND ORIGIN}

An eolian origin for most of the silt in the fine-grained mantle is suggested by the following evidence: (1) The silt invariably contains some minerals foreign to the underlying bedrock and therefore consists partly of transported material; (2) the fact that it is 
generally extremely well sorted suggests deposition by a highly selective transportation process; (3) it is nearly massive and fails to display bedding or other minor structures suggestive of deposition by flowing water; and (4) it is found in positions in which it could have been introduced only by wind.

The coarse particles of local rocks and minerals that are commonly mixed in the silt represent material separated from underlying bedrock, chiefly by frost riving, before or during the accumulation of the silt. Most of the silt was deposited and most of the frost riving of bedrock took place nearly simultaneously during glacial intervals. At first, silt borne by wind from nearby glacial outwash plains settled into the interstices of freshly frost-rived rubble; as more silt accumulated, the rubble became filled and then covered. The mixture of rubble and silt became perennially frozen within 1 or 2 feet beneath the surface, and the bedrock was insulated from further frost riving. However, frost churning within the surficial layer, which was subject to annual freezing and thawing, caused some of the previously detached rock fragments to migrate upward into newly deposited silt as the mantle thickened. Thus, scattered fragments of local bedrock were incorporated into all except the highest parts of the thickest mantles.

Much of the windblown silt evidently was deposited before the extinction of the Pleistocene fauna on Seward Peninsula. Fragmentary remains of mammoths have been found in windblown silt at Imuruk Lake and at Lava Lake in places where they could only have been derived from windblown silt. The tip of a well-preserved tusk found protruding above the surface of a beach on the west shore of Salix Bay, Imuruk Lake, proved to be embedded in compact blue-gray silt (column F, table 1 and specimen F, fig. 7) that underlay beach gravel at a depth of 1 foot. Mammoths and other extinct species of the Pleistocene fauna have been found on Seward Peninsula only in deposits determined by radiocarbon methods to be 10,000 years old (Hopkins, 1959b, p. 1043).

Thick deposits of windblown silt are found chiefly in areas north and east of areas of the Nome River (Illinoian) glaciation (pl. 3) ; only thin deposits of windblown silt are found within the areas of the Nome River glaciation. In the Imuruk Lake area, the mantle of windblown silt is not a recognizable entity in the small areas covered by glaciers of Nome River age, although it is present immediately outside of the glaciated areas. This distribution pattern indicates that the greater part of the windblown silt was deposited during the Nome River (Illinoian) glaciation. 
Windblown silt; generally less than 5 feet thick, covers drift of Nome River (Illinoian) age at Nome (Hopkins, MacNeil, and Leopold, 1960), and a patchy mantle of silt, a few feet thick, rests on lava flows of the Gosling volcanics in the Imuruk Lake area, one of which partly buries an end moraine of Nome River (Illinoian?) age. Most of this younger silt is evidently of Salmon Lake (Wisconsin) age.

Still younger silt is found in patches, a few inches thick, on the western parts of the Lost Jim and Camille lava flows. The silt on the Lost Jim lava flow must have been deposited during the last thousand years (p. C71).

The distribution of thick deposits of windblown silt in areas along the north and east margins of the intensely glaciated areas indicates that most of the silt was derived from the windswept flood plains of melt-water streams draining glaciers. Large outwash fans of Nome River and Salmon Lake age form an apron sloping from the flanks of the Bendeleben Mountains into the Kuzitrin flats and are the probable source of most of the windblown silt in the Imuruk Lake: area. Minor quantities of silt, however, have been redistributed by wind in more recent times and must have been derived from other sources. Moreover, the silt-sized particles of basaltic minerals found in specimens of all ages-including specimens collected on schist bedrock-also may require some source other than glacial-outwash plains, because the glacial ice crossed few, if any, areas of basalt.

Sources that merit consideration include the areas of braided channels that are found on the sites of river icings (aufeis) (described more fully in Hopkins, Karlstrom, and others, 1955, p. 114, 121, 141, and pl. 43) and the abundant small areas of bare ground that result from intense frost-heaving in fine-grained soils covered by tundra- vegetation (Hopkins and Sigafoos, 1951, p. 66-70, figs. 25 and 27).

Frost-disturbed soils have been suggested as a major source of Pleistocene windblown silt (loess) in Europe (Dücker, 1937; Troll, 1944, p. 573-574). On Seward Peninsula, however, frost scars seem to be capable of contributing only minor quantities of windblown silt, either at present or during past glacial intervals. Evidence of deflation was occasionally noted by me on the surfaces of frost scars, but more commonly their surfaces were sticky when wet and bricklike and seemingly unerosible when dry.

Braided stream channels resulting from icings are common in the uplands adjoining the Imuruk Lake area but are scarce within the 
lava plateau. Their areal extents are individually small. Clouds of dust rose 200 to 300 feet above the braided channels of the Inmachuk River on windy days in August 1949 and resulted in the deposition of small quantities of silt on the lower walls of the Inmachuk River valley.

Probably frost scars and braided flood plains on the sites of icings have furnished a minor part of the windblown silt deposited during glacial intervals and a much larger proportion. of the small increment of silt that has been added during nonglacial intervals.

\section{ALLUVIUM AND. COLLUVIUM}

Gravel alluvium underlies the flood plains and low terraces of the larger streams (pl. 1); deposits of stratified silt and peat fill the valleys of minor streams and mantle the lower flanks of adjoining hillslopes (not mapped as a separate unit on pl. 1). The stratigraphy of these alluvial and colluvial sediments suggests a complex late Quaternary history, but most of the exposures upon which an analysis must be based lie beyond the limits of the Imuruk Lake area.

\section{GRAVEL}

Waterworn gravel of late Quaternary age is found beneath flood plains and in low terraces in the valleys of the larger streams. The gravel ranges in thickness from 2 feet in headwater valleys to several tens of feet in the Kuzitrin flats and probably in the Koyuk River valley at the southeast corner of the map area (pl. 1). Much of the gravel is perennially frozen, but unfrozen zones are common near the basal contact and in other places where permeability is high and a supply of ground water is available.

The gravel generally is well sorted but poorly rounded. Typical deposits consist of angular to subrounded pebbles and cobbles, as much as 4 inches across, in contact with one another; the interstices are filled with coarse sand. A few boulders, 8 to 12 inches across, are scattered through the pebble-cobble gravel. The pebble lithology closely reflects the bedrock lithology of the valley in which the gravel is found. The gravel is at least sparsely auriferous in most valleys draining areas of Paleozoic metamorphic rocks. Bones of extinct mammals are found in gravel mined for gold at Black Gulch (fig. 8) (Frank Whaley, Rainbow Mining Co., oral communication, 1948). The deposits probably range in age from early Illinoian to Recent.

A weathered zone is generally present beneath the gravel of late Quaternary age. Schist bedrock is commonly but not invariably weathered to a pulpy mass of rusty quartz-mica sand; metalimestone is locally weathered to limy grit. Foliation, joints, and primary 
bedrock structures generally remain recognizable. The weathered zone generally is less than 3 feet thick, but locally reaches a thickness of 15 feet. Some of the thicker maisses of rotten rock may be products of subaerial weathering prior to deposition of the gravel; much of the weathering, however, must have occurred after deposition of the gravel, for some of the delicate structures preserved in the rotten rock could hardly have resisted destruction by the turbulent currents that transported the gravel. Most of the rotten rock probably was altered by ground water circulating after burial in unfrozen zones at the bedrock-gravel contact.

\section{STRATIFIED SHT AND PEAT}

Aprons of stratified silt and peat mantle the lower slopes of most hills in the Imuruk Lake area and adjoining parts of the uplands; similar material blankets the flood plains of many streams (Hopkins, Karlstrom, and others, 1955, pls. 30 and 31). Stratified silt and peat is not shown as a separate unit on plate 1, because it forms a general blanket on the lower parts of all slopes covering parts of nearly all the other geologic units. It rests on alluvial gravel in valley bottoms, on low stream terraces, in minor gullies and swales, and on lacustrine sediments in the terraces at Imuruk Lake; in other places it rests directly on bedrock or on windblown silt (fig. 8).

The stratified silt and peat ranges in thickness from a few feet to more than 40 feet. It is thickest at the edges of valley flats and on the lower parts of valley walls. Like the windblown silt, it is perennially frozen nearly everywhere and generally contains large quantities of clear ice in the form of vertical wedges arranged in polygonal networks, as well as abundant small tabular lenses parallel to bedding.

The deposits of stratified silt and peat differ widely in origin and age. Deposits forming aprons on valley walls are chiefly colluvial in origin and have been derived by a variety of processes from materials originally deposited by wind or freed from bedrock by frost action farther upslope. Deposits in valley bottoms include typical flood-plain silts and materials that accumulated in small ponds. The mineralogy and texture of the inorganic fraction indicates that most of the silt consists of reworked windblown silt (specimen TE in fig. $7 D$; columns I-L in table 1 ). The deposits range in age from Illinoian to Recent.

Well-preserved logs of spruce, poplar, and birch are found in some deposits of stratified silt and peat, although the Imuruk Lake area now lies several tens of miles west of the western limit of spruce and birch forest. The presence of tree-sized logs in the $6806110-63-4$ 


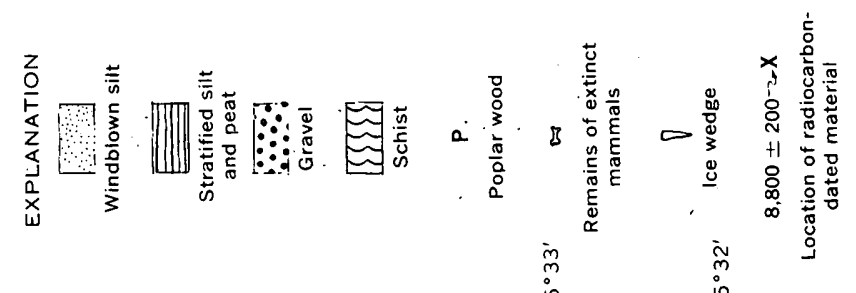

苞高

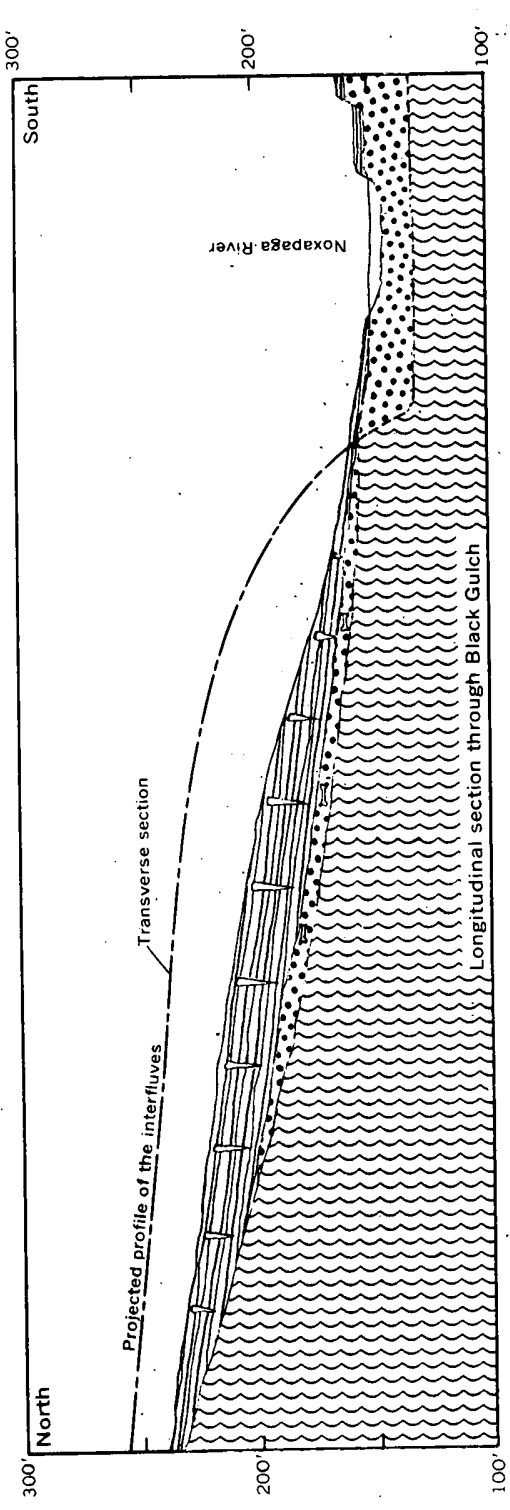

家
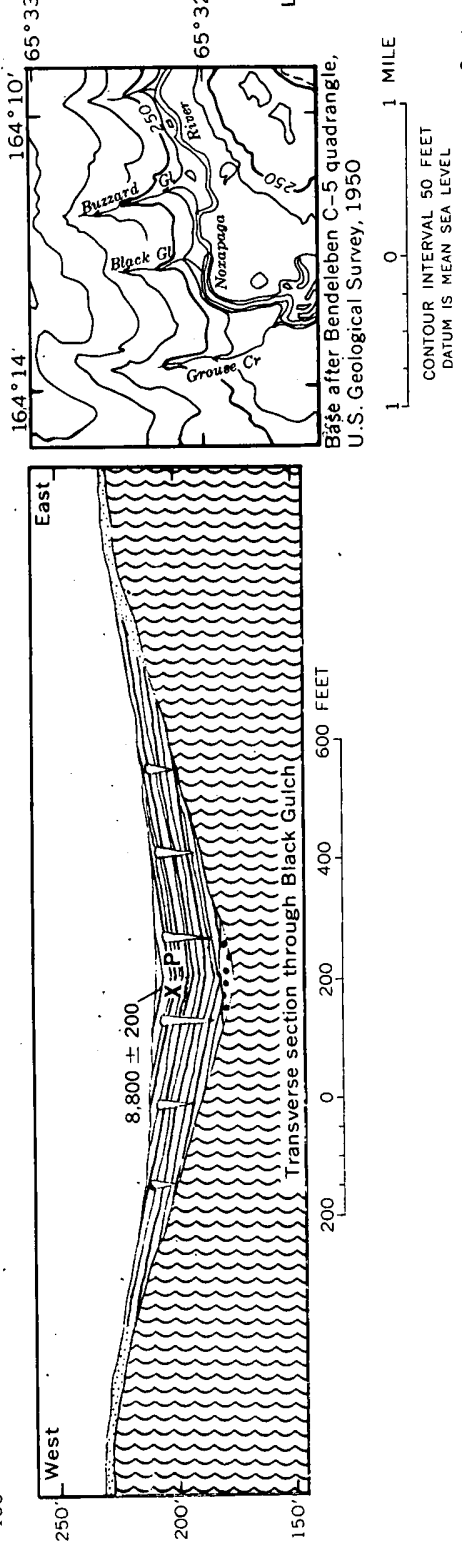

อํㅝㄹ

눌

章

(4)

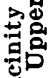

>

형

윰요

용

通我

홍명

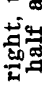

놈

递

के

实

논

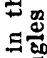

오요

봄명

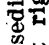

के

명

형리

品

可

苛通

1 .

$\left.\infty)^{\circ}\right)_{0}$

国牙 
stratified peat and silt indicates that part of the material accumulated during intervals when summers were warmer than at present (Hopkins, 1959c). Fossil beaver dams are commonly found in placer-mining excavations in stratified silt and peat whose age has been determined by radiocarbon methods to be 3,600 years and 8,000 to 10,000 years (Hopkins and Giddings, 1953, p. 26-28). Beavers reach the western limit of their present-day range at the eastern base of Seward Peninsula, about 50 miles east of the Imuruk Lake area.

\section{LACUSTRINE BEDIMENTS} IMOROK LAKE

Three systems of abandoned shoreline features are found at different levels along the shores of Imuruk Lake. The highest, of probable Illinoian age, is a wave-cut scarp without associated sediments 5 (hachured line along north shore of Imuruk Lake on pl. 1). The intermediate system includes two groups of terraces which seem to have accumulated during two distinct intervals of high lake level during Wisconsin time; the terraces consist of beach gravel, lacustrine silt, nonlacustrine stratified silt and peat whose texture and mineralogy indicate an ultimate origin as windblown silt (curves $\mathrm{I}$, $\mathrm{J}$, and $\mathrm{K}$ in fig. $7 D$ and table 1 ), and both detrital and autochthonous peat. A layer of brown or pink volcanic ash, described on page C71, lies near the tops of the terraces of the older group but is lacking in the younger group. The lowest system of terraces is of Recent age and consists chiefly of beach gravel and autochthonous peat.

The wave-cut scarp and the intermediate terraces have been upwarped about 40 feet on the shores of Salix Bay and Salix Peninsula; the wave-cut scarp can be traced at progressively lower elevations to present-day lake level southeast of Granite Bay. The lowest terrace is almost horizontal. Several lines of evidence, cited in Hopkins (1959b), suggest that Imuruk Lake drained westward through an unnamed northern tributary of Carex Creek to the Noxapaga River at the time when the highest and intermediate shorelines were occupied and that the present outlet to the Kugruk River was initiated relatively recently.

\footnotetext{
5 The description of the lacustrine sediments and history of Imuruk Lake given here and in the section entitled "Geologic History" summarize a more detalled account presented in Hopkins $(1959 \mathrm{~b})$. During a revisit to Imuruk Lake in 1961, however, I recognized that most of the sediments of the Intermediate terraces must have accumulated at approximately the same time that the wave-cut scarp was being carved. Two driftwood specimens from the intermediate terraces are $9,900 \pm 400$ and $7,400 \pm 300$ years old. (Specimens W1213 and W1235, Meyer Rubin, written communication, 1963 ).
} 
OTHER LAKES

Lacustrine sediments similar in character and probably in age to those of the intermediate terraces of Imuruk Lake form a 10-foot terrace at Sandy Lake and underlie an extensive surface 5 to 10 feet above the level of the cluster of lakes in the valley of Andesite Creek, 1 mile west of Lava Lake. The fact that the brown ash layer appears near the top of these terraces suggests correlation with "the older of the two groups of intermediate terraces at Imuruk Lake. Lava Lake, Kuzitrin Lake, and Cloud Lake are adjoined by terraces comparable in height and composition and probably in age to the lowest terraces at Imuruk Lake; the terraces at. Lava Lake are too narrow to be shown on plate 1 .

\section{DRAINED OR FILLED LAKES}

The beds of drained or filled lakes occupy several extensive tracts in the Imuruk Lake area, shown as undifferentiated lake sediments on plate 1. None of the-larger drained lakes were visited in the field, but aerial examination suggests that thick peat lies immediately beneath the surface. Lacustrine silt probably underlies the peat and may extend to depths of several tens to several hundreds of feet. Most of the drained or filled lakes occupy initial low areas on lava flows of the Imuruk volcanics, but the long narrow lake basin northeast of Kettle Dome occupies an ancient stream valley carved in schist or granite and blocked at its north end by a lava flow of the Imuruk volcanics.

The floor of the large lake basin between Largo Ridge and the upper Goodhope River slopes northward at a gradient of about 10 feet to the mile. The basin now drains northward to the Goodhope River, but study of aerial photographs suggests that the former lake in this basin drained southward to the Noxapaga River. The floor of the lake basin evidently has been tilted northward.

\section{DIATOMOTE IN VALLEY OF ANDESITE CREEK}

The undifferentiated lake sediments south and southwest of Lava Lake in the valley of Andesite Creek (pl. 1) consist of diatomite that accumulated in a lake formerly confined by the Camille lava flow but now almost completely drained. The floor of the lake was later invaded and most of the diatomite buried by the Lost Jim lava flow. The diatomite presumably is continuous beneath the tongue of the Lost Jim lava flow that separates the four isolated exposures shown on plate 1 . 
The diatomite is younger than the Camille lava flow and older than the Lost Jim lava flow; its age is therefore late Wisconsin or early Recent. It is probably of approximately the same age as the lowest terraces at Imuruk Lake.

\section{VOLCANIC ROCKS}

Lava flows of late Cenozoic age cover most of the Imuruk Lake area. Nearly all the flows are of the pahoehoe type; but aa flows, short steep-sided flows of block lava (Macdonald, 1953), and endogenous domes ${ }^{6}$ are present locally. Most of the lava flows were emitted from short-lived vents that gave rise to only 1 or 2 flows and probably remained active for only a few years. A few small shieldlike central volcanoes, such as Hoodoo Hill and Twin Calderas (pl. 1), probably were longer lived.

Basalt and basaltic andesite are the predominant petrographic types. The flows differ in character of phenocrysts and degree of crystallinity, but these differences are apparently random in space and time. A swarm of vents concentrated in a belt trending northwest from Blueberry Dome to the head of Trail Creek emitted lava containing conspicuous and abundant xenocrysts and inclusions of olivine, opacite (chrome spinel?), orthoclase, oligoclase, dunite, granitic rock, and schist.

Five volcanic formations-the Kugruk volcanics, the Imuruk volcanics, the Gosling volcanics, the Camille lava flow, and the Lost Jim lava flow-are distinguished on the basis of degree and character of weathering, the degree of modification of primary surface relief, and the presence or absence of a thick cover of windblown silt. The Kugruk volcanics are of late Tertiary and possibly of early Pleistocene age; they are equivalent in age to part of the Kougarok gravel. The Imuruk volcanics were emplaced during early and middle Pleistocene time prior to the end of the Nome River (Illinoian) glacial interval. The Gosling volcanics were emplaced during the Nome River-Salmon Lake (Sangamon) interglacial interval and the Salmon Lake (Wisconsin) glacial interval; the Camille lava flow, during late Wisconsin time; and the Lost Jim lava flow, during late Recent time. Pyroclastic deposits are represented only by agglomerate and cinders forming small cones at some volcanic vents; coarse pumice scattered over some of the young lava flows near their vents; and a thin but widespread layer of

\footnotetext{
6 Endogenous domes are steep-sided protrusions of viscous lava forming more or less dome-shaped or bulbous masses over and around the volcanic vent (Williams, 1932).
} 
brown ash erupted from an unknown source in the. Imuruk area at some time during the Salmon Lake (Wisconsin) glacial interval. Because the five volcanic formations cannot be distinguished from one another petrographically, their petrography is discussed collectively in a section that follows the stratigraphic and geomorphic descriptions of each formation.

Continuing volcanic activity in the Imuruk Lake area throughout late Tertiary and Quaternary time has resulted in an impressive volume of extrusive rocks, but the individual eruptions may have been rather widely spaced in time. Only the Lost Jim lava flow and the Camille lava flow have been erupted during the last 10 or 20 thousand years. The Gosling volcanics probably represent the results of 10 to 20 separate eruptions, occurring sporadically over a period of at least 100,000 years. The much larger number of lava flows included in the Imuruk and Kugruk volcanics were erupted sporadically over a much longer: span of time. It seems that volcanic eruptions in the. Imuruk Lake area have taken place at an average rate of 1 per 5,000 to 10,000 years.

\section{STRATIGRAPHY KOGROK VOLCANICS}

LITHOLOGY AND STRATIGRAPHY

The name Kugruk. volcanics is proposed for a group of volcanic rocks in the Imuruk Lake area that are characterized by a thick weathered zone unlike weathered zones formed in similar rocks under the present climate. Some volcanic rocks lacking this characteristic weathering profile are assigned to the Kugruk volcanics, because they are much more dissected than rocks assigned to the next younger formation, the Imuruk volcanics. The formation is named for the type locality in the canyon of the Kugruk River, 3 miles east of Imuruk Lake.

The Kugruk volcanics range in composition from olivine basalt to pilotaxitic andesite. Inclusion-bearing rocks are common. The formation includes lava flows (generally seen only in the walls of deep canyons incised below overlying lava flows of the Imuruk volcanics), deeply dissected volcanic cones and necks, several probable endogenous domes, and several small masses of volcanic rock of undetermined origin.

\section{DISTRIBUTION}

The Kugruk volcanics are best exposed in the cliffed east wall of the canyon of the Kugruk River, $\cdot 3$ miles. below Imuruk Lake (fig. $9)$. The section near the head of the canyon is as follows: 


\begin{tabular}{|c|c|c|}
\hline Stratigraphic unit & $\begin{array}{c}\text { Thickness } \\
\text { (feet) }\end{array}$ & Lithology \\
\hline $\begin{array}{l}\text { Imuruk volca- } \\
\text { nics. }\end{array}$ & 40 & $\begin{array}{l}\text { Olivine-basalt lava flow, free of inclusions. Surface } \\
\text { consists of frost-rived boulders and pebbles. } \\
\text { Ferromagnesian minerals within an inch of the } \\
\text { surface of individual fragments are impregnated } \\
\text { with limonite, but rock is hard and firm; rings } \\
\text { under blow by hammer. } \\
\text { Conformable contact. }\end{array}$ \\
\hline $\begin{array}{l}\text { Kugruk volca- } \\
\text { nics. }\end{array}$ & $40^{\circ}$ & $\begin{array}{l}\text { Olivine-basalt lava flow, containing large angular } \\
\text { xenocrysts of orthoclase and lustrous opacite } \\
\text { (chrome spinel?) and inclusions of granitic rock } \\
\text { and dunite. Base of flow is reddened, chilled, and } \\
\text { glassy. Flow has rude columnar jointing. Deeply } \\
\text { weathered throughout entire thickness of flow; in } \\
\text { many places rock is friable, crumbling under blow } \\
\text { by hammer; elsewhere it breaks up into limonite- } \\
\text { coated walnut-shaped fragments an inch or two } \\
\text { long. }\end{array}$ \\
\hline $\begin{array}{l}\text { Kugruk } \\
\text { volcanics. }\end{array}$ & $20+$ & $\begin{array}{l}\text { Basaliic-andesite lava flow containing sparse olivine } \\
\text { phenocrysts but free of inclusions and recognizable } \\
\text { xenocrysts. Top } 3 \mathrm{ft} \text { strongly oxidized. Deeply } \\
\text { weathered; weathering characteristics similar to } \\
\text { overlying, inclusion-bearing flow. } \\
\text { Base of cliff obscured by olivine-rich basalt flow of } \\
\text { Gosling volcanics that occupies most of narrow } \\
\text { floor of canyon. }\end{array}$ \\
\hline
\end{tabular}

The Kugruk volcanics seem to reach considerably greater thickness in areas farther downstream that were not visited on the ground.

Lava flows and pyroclastic rocks of the Kugruk volcanics are exposed in the canyon walls of Bilgewater Creek, 1.8 miles above the junction with the Goodhope River, and in the canyon walls of Cottonwood Creek, 3 miles upstream from the junction with Trail Creek (pl. 1). In each valley a single flow assigned to the Kugruk volcanics is exposed beneath two or more flows of the Imuruk volcanics, having an aggregate thickness of about 50 feet. The lava flow of Kugruk volcanics in Cottonwood Creek valley is about 50 feet thick. The maximum exposed thickness of the flow in the valley of Bilgewater Creek is about 20 feet, but the base is covered. The flow in Cottonwood Creek valley contains abundant mafic inclusions; no inclusions or xenocrysts were recognized in the Bilgewater Creek exposures. In both valleys the flows are deeply weathered throughout their exposed thickness. Deeply weathered schist underlies the flow in Cottonwood Creek valley.

In both valleys, the Kugruk volcanics are found only near the heads of the canyons, where the streams first cut below the base of 

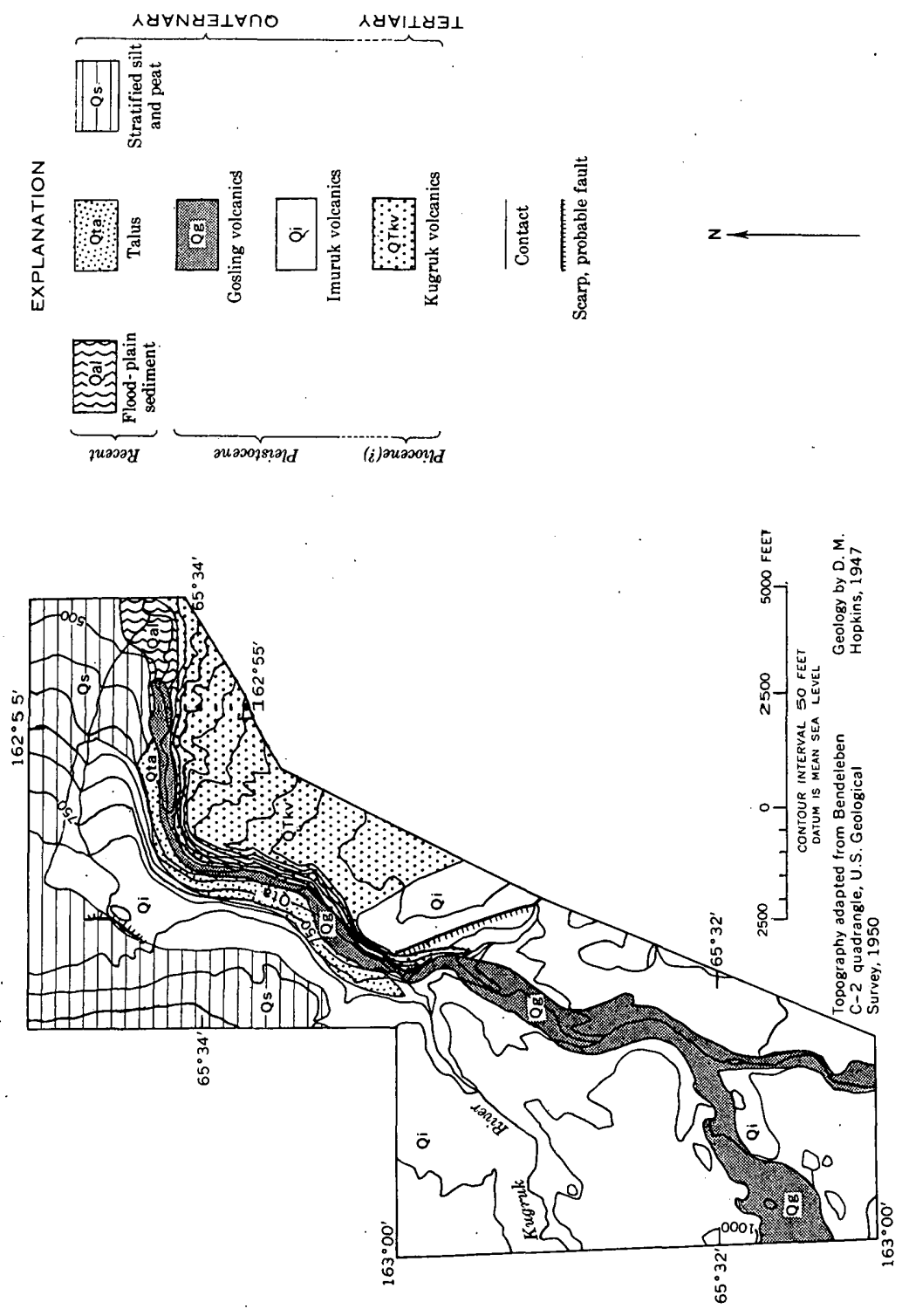
the overlying Imuruk volcanics. Farther downvalley, Imuruk volcanics rest directly on bedrock of schist and metalimestone at altitudes higher than the exposures of Kugruk volcanics. The exposed lava flows of Kugruk volcanics probably occupy a shallow buried valley extending transverse to the present courses of Cottonwood and Bilgewater Creeks.

Two deeply eroded volcanic necks composed of inclusion-bearing basalt are exposed on the north wall of Cottonwood Creek canyon, 0.8 mile downstream from the outcrops of lava flows of the Kugruk volcanics. The necks form slender spires on the canyon wall, rising several hundred feet above the valley bottom. They are rectilinear plugs of basalt about 100 feet across and are surrounded by calcareous schist that forms the canyon walls in this area.

The necks show a strongly developed steeply dipping platy structure consisting of alternate zones, a few inches thick, of vesicular basalt and massive basalt. The margins of the necks and the surrounding schist are oxidized a deep red. The necks are partly surrounded and capped by breccia composed of angular schist fragments, dark dense basalt fragments, and basaltic scoria. The breccia probably represents remnants of the cinder cones that originally surrounded and capped the necks. One of the necks probably was the source of the lava flows of Kugruk volcanics exposed in the canyons of Cottonwood and Bilgewater Creeks.

A circular mound of inclusion-bearing agglomerate, a few hundred feet in diameter and less than 5 feet high, surrounded by a sheet of boulders of dense inclusion-bearing basalt, is found on the flat top of the ridge separating Trail Creek and Divide Creek, 2.2 miles northeast of the junction of Trail and Cottonwood Creeks. The mound of agglomerate probably marks an ancient volcanic vent, and the adjoining sheet of basalt boulders probably represents the remnant of a deeply weathered and frost-rived basalt flow. These rocks are assigned to the Kugruk volcanics on the basis of their apparent degree of dissection.

Small bodies of Kugruk volcanics 1.1 miles south-southeast of Virginia Butte, at the summit of Kettle Dome, and on the northeast shore of Imuruk Lake may represent dissected endogenous domes.

The body near Virginia Butte is a small conical hillock composed of sheeted inclusion-bearing andesite. The sheet fractures dip $22^{\circ}$ SW. The hillock evidently represents an erosional remnant of a formerly more extensive body.

At the summit of Kettle Dome is a knob-shaped protuberance, 45 feet high and 1,000 feet in diameter, composed of dense nonvesicular pilotaxitic andesite. The summit surface of the hillock is lit- 
tered with deeply weathered walnut-sized andesite fragments. Its steep walls expose andesite in place, cut by horizontal joints at intervals of 2 feet and by two sets of vertical joints at intervals of 5 feet. The surrounding area is mantled by windblown silt extending to depths greater than the permafrost table. Scattered small rocks at the surface several thousand feet from the summit of Kettle Dome suggest that the andesite hillock is surrounded by quartz monzonite and schist.

Kugruk volcanics also are exposed along the abandoned tilted shoreline of Imuruk Lake, 0.4 mile southeast of Granite Bay. The exposed rocks consist of an inclusion-bearing sill or flow and an intruded. small plug of fine-grained olivine basalt. The plug is about 40 feet in diameter and seems to have been conical in its original form. Well-developed columnar jointing converges toward a point about 20 feet above the present top of the outcrop. The columns in the center of the plug are vertical, but those at the margins pitch radially outward at angles as low as $60^{\circ}$. From a distance the outcrop resembles a bundle of faggots tied at the top.

The other recognized exposures of Kugruk volcanics are as follows: Deeply weathered, slightly serpentinized boulders of basalt at the summit of Blueberry Dome; a bench that possibly may represent the remnant of a dissected flow on a hill 2.5 miles west of Blueberry Dome; and a basaltic lava flow, locally deeply weathered, interbedded with Kougarok gravel in terraces along the Noxapaga River, 0.7 mile and 2. miles upstream from the mouth of Grouse Creek.

WEATHERING PROFILE

At several localities the Kugruk volcanics are characterized by a weathering profile unique in the Imuruk Lake area and strikingly different in character from weathering profiles that developed on basalt during the late Pleistocene and Recent time in northern Seward Peninsula (p. C57). The weathering profile is well preserved only in areas where Kugruk volcanics are buried beneath unweathered Imuruk volcanics or Kougarok gravel; the weak weathered rock is assumed to have been stripped by solifluction and rill erosion wherever Kugruk volcanics crop out at the surface.

In the most deeply weathered Kugruk volcanics (fig. 10), chemical decomposition has altered rock within a few inches of joints and fractures to a friable sandy mixture of feldspar, limonite, and clay. Farther from the joints, the rock is intimately penetrated by veinlets of yellow-brown limonite, and the dark minerals are completely altered to limonite. Some fracture surfaces are coated with an iridescent blue stain, possibly a manganese oxide. The cores of the joint blocks are spheroids, ellipsoids, or disks of rela- 


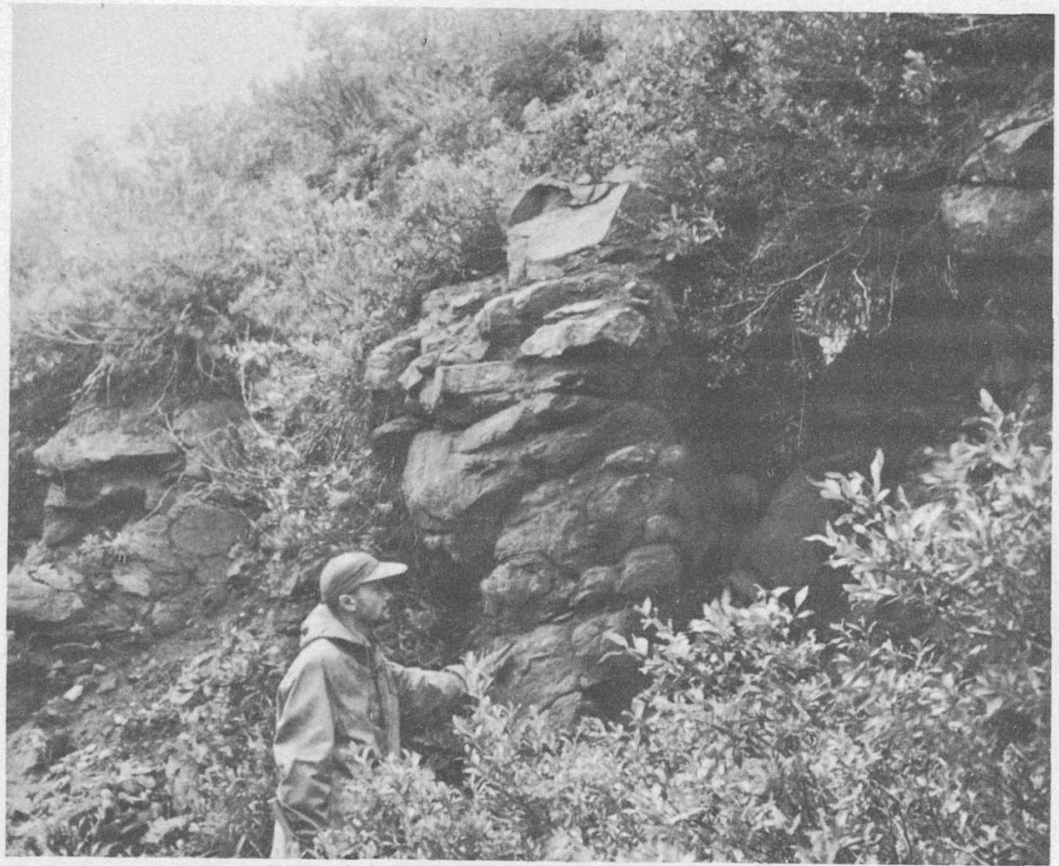

Figure 10.- Spheroidal weathering in basaltic lava flow of the Kugruk volcanics exposed in canyon of Bilgewater Creek.

tively firm basalt (fig. 10), which, however, can be scratched and disintegrated with a pick. The central spheroids spall along concentric fractures to give curved plates of rotten basalt. Weathered rock of this character were observed to extend at least 15 feet beneath overlying unweathered Imuruk flows.

At greater depths, the Kugruk flows are firm but mottled dark and light gray on vertical exposures. The dark-gray material is more resistant to present-day weathering than is the light-gray matrix; exposed boulders have a knobby appearance, and outcrops are skirted by aprons of walnut-shaped fragments of the darker lava 1 or 2 inches in diameter. Somewhat similar weathering was noted in an inclusion-bearing member of the Gosling volcanics at Virginia Butte; knobby weathering possibly may be a characteristic of inclusion-bearing flows rather than a characteristic of the lower part of the post-Kugruk weathering profile.

AGE

A flow assigned to the Kugruk volcanics is overlain by gravel representing part of the upper member of the Kougarok gravel in terraces along the Noxapaga River. There and elsewhere, the flows of the Kugruk volcanics are weathered to depths of $15-40$ feet below their upper surfaces; the weathering profile differs in character 
and depth from that displayed by lava flows of the Imuruk volcanics. The depth of the weathering suggests a climate much warmer than at present. The weathering may have taken place during the interglacial interval that separated the Iron Creek (Kansan?) and Nome River (Illinoian) glaciation, an interglacial interval that evidently was warm enough to permit the growth of Douglas fir on Seward Peninsula. A climate sufficiently warm to cause the weathering profile observed in the Kugruk volcanics seems more nearly consistent, however, with the late Tertiary flora found in the middle member of the Kougarok gravel. The Kugruk volcanics are probably largely of late Tertiary age but may include some lava flows of early Pleistocene age.

\section{IMOROK VOLCANICS}

LITHOLOGY AND STRATIGRAPHY

The name. Imuruk volcanics is proposed for a group of basaltic lava flows and associated agglomerate cones that have been exposed so long that in most places their surfaces have been thoroughly brecciated by frost action and mantled by a layer of windblown silt 3 to 20 feet thick. Imuruk Lake, for which the formation is named, occupies a vaguely defined graben whose bounding faults displace lava flows of the Imuruk volcanics. The oldest shoreline of the lake is, in places, notched in the:Imuruk volcanics (pl. 1, this report; Hopkins, 1959b). The relationships between the Imuruk volcanics and older and younger volcanic formations are most clearly displayed, however, at the type locality in the canyon of the Kugruk River, 3 miles below Imuruk Lake (fig. 9). Here, unweathered lava flows of the Imuruk volcanics overlie deeply weathered lava flows of the Kugruk volcanics, and a lava flow of the Gosling volcanics has invaded a canyon excavated into and below the Imuruk volcanics.

\section{DISTRIBUTION}

The Imuruk volcanics are the most widely distributed volcanic rocks in north-central Seward Peninsula. They underlie most of the Imuruk Lake lava plateau, including most areas covered by younger volcanic rocks. Lava, now represented by benches high on the valley walls, flowed down the valleys of the Koyuk, Kugruk, Burnt, Inmachuk, and Goodhope Rivers, locally extending to the coast of Kotzebue Sound (pl. 2, this report; Hopkins, Karlstrom, and others, 1955, pl. 30$)$.

The Imuruk volcanics were emplaced upon a rolling surface having a local relief of several hundred feet. Consequently, the thickness of the formation varies widely, and the maximum thickness cannot be estimated accurately. Exposures in valleys draining the 
northern part of the lava plateau range in thickness from a few tens of feet to two hundred feet. Most of the plateau is probably underlain by several hundred feet of Imuruk volcanics.

A rolling terrain having several hundred feet of relief was almost completely buried by the Imuruk volcanics in the area between the Bendeleben Mountains and the Asses Ears; only a few of the highest eminences in the pre-existing bedrock topography, such as Kettle Dome and The Bat, protrude above the surface of the volcanics. A major buried valley trending due west from the head of Cottonwood Creek canyon across the present course of Bilgewater Creek and the head of the canyon of the Goodhope River is suggested by the distribution of exposures of the Kugruk volcanics and of zones in which especially large thicknesses of Imuruk volcanics are found north of the Asses Ears and Cottonwood Creek. The Imuruk volcanics invaded the northward-draining valleys of the Goodhope, Inmachuk, Pinnell, Burnt, and Kugruk Rivers but did not accumulate to sufficient depth to bury the interfluves. The ancestral northward-draining valleys occupied by the lava flows were considerably shallower, broader, and more mature than the present valleys of these northward-flowing streams (Hopkins, Karlstrom, and others, 1955 , pl. 30), and they have been tilted northward since the flows were emplaced.

\section{ERUPTIVE HABIT}

The Imuruk volcanics consist chiefly of basaltic lava flows erupted from generally short-lived vents scattered throughout the lava plateau. Individual flows range from 10 to 50 feet in thickness at their fronts but are much thicker near their source vents. Hills, each apparently composed of a single flow, rise as much as $\mathbf{1 5 0}$ feet above the surrounding terrain. Most of the lava flows are of the pahoehoe type. Characteristic filamented or festooned pahoehoe surface textures ${ }^{7}$ are preserved on scattered boulders, and most rock fragments contain the spherical or elliptical vesicles characteristic of pahoehoe lava rather than the irregular distorted vesicles typical of aa lava (Macdonald, 1953). The relatively great fluidity of many of the flows is indicated by low flow fronts and by the fact that relatively thin flows extended down the valleys of the Inmachuk and Pinnell Rivers for at least 15 miles from their source vents.

Hoodoo Hill and, possibly, Largo Ridge represent shield volcanoes composed of several flows emitted from single vents or fissures. The older flows forming Hoodoo Hill have a relatively thick cover of windblown silt and, consequently, are assigned to the Imu-

7 The names used for surface textures of lava are those proposed by Wentworth and Macdonald (1953). 
ruk volcanics. The surfaces of the youngest flows, however, consist of openwork rubble containing only interstitial silt; and the flows are therefore assigned to the Gosling volcanics. Largo Ridge is apparently entirely composed of Imuruk volcanics.

Pyroclastic deposits are represented only by agglomerate cones over some of the source vents. The largest, Rhododendron Cone, stands 160 feet above surrounding terrain. Andromeda Cone and Cassiope Cone are about 75 feet high. Other vents are marked by small, generally craterless mounds of agglomerate ranging from 5 to 50 feet in height. Many vents have no associated cone deposits and can be approximately located only on the assumption that they lie somewhere beneath the highest part of an individual lava flow.

WEATHERING AND EROSION

Surfaces underlain by the Imuruk volcanics form a smooth rolling terrain bearing a complete or nearly complete cover of vegetation. The gross relief features are generally constructional, but the rugged microrelief that may be assumed to have characterized the flows when first emplaced has been entirely smoothed and obscured by frost riving; solifluction, and the deposition of a thick mantle of windblown silt. If spatter cones and cinder cones were not visible in a few localities, it would not be obvious that the topography is volcanic in origin. The typical topography of an area underlain by Imuruk volcanics is shown on figure 15. (See also Hopkins, Karlstrom, and others, 1955, pl. 31).

An extensive but poorly integrated surface drainage system has formed on the silt mantle covering the Imuruk volcanics. Marshes and thaw lakes are abundant in lowlands and on some hill summits. Locally, small streams or marshes drain into thaw sinks, where they percolate into the underlying volcanic rocks (Hopkins, 1949). Throughout most of the area, the streams follow the initial low. parts of the surface of the volcanic rocks, and only a few of the largest or most favorably situated streams appear. to have enlarged their valleys by fluvial erosion.

The mantle of windblown silt on the surface of the Imuruk volcanics ranges in thickness from a few feet to several tens of feet, and the topography of the lava surface varies accordingly. Flows deeply mantled with silt bear a nearly unbroken cover of vegetation, and rock fragments are scarce or lacking at the surface. Flows covered by only a few feet of silt, on the other hand, bear a discontinuous cover of vegetation in which surface boulders are abundant. 
The weathering profile in a flow of the Imuruk volcanics exposed at the point where the Pinnell River leaves the lava plateau was examined in order to establish a basis for comparison with weathering profiles developed on flows of the Kugruk volcanics. The surface of the flow seems to have undergone little or no erosion; the flow is mantled with windblown silt, 1 to 4 feet thick, containing scattered boulders of basalt.

Weathering extends down fractures and joints to a depth of at least 20 feet beneath the silt, as indicated by slight orange-limonite staining and by blue iridescent staining on joint surfaces. Pyroxene and olivine grains within a few inches of the joints have been impregnated or replaced by limonite. Farther in from the joints, the rock is fresh and unaltered. The parts of the rock in which dark minerals have been limonitized remain firm and hard; they ring under a blow of the pick. No suggestion of spheroidal weathering was noted anywhere in the weathering profile exposed in the Pinnell Canyon or elsewhere in flows of the Imuruk volcanics exposed at the present surface.

The great total thickness and horizontal extent of the Imuruk volcanics and the wide range in the thickness of windblown silt that covers individual flows suggest that the Imuruk volcanics were extruded over a relatively long time span.

The Imuruk volcanics do not show the deep weathering profile and the spheroidal weathering phenomena that characterize the Kugruk volcanics and that are believed to be the products of weathering in the warm climate of late Tertiary time; instead, the upper parts of the flows consist of openwork frost-rived rubble grading up into rubble with a matrix of windblown silt. Lava flows of the Imuruk volcanics were evidently exposed to strong frost action shortly after extrusion and thus must be of Pleistocene age.

Most of the windblown silt in the Imuruk Lake area was probably deposited during the Nome River (Illinoian) glacial interval. Lava flows of the Imuruk volcanics that bear a thick mantle of silt were probably emplaced before the beginning of the Nome River (Illinoian) glacial interval, and lava flows bearing a relatively thin mantle of silt were probably emplaced at some time during the Nome River (Illinoian) glacial interval. The Imuruk volcanics thus include lava flows of middle and, probably, of early Pleistocene age.

\section{GOSLING VOLCANICS}

LITHOLOGY AND STRATIGRAPHY

The name "Gosling volcanics" is proposed for a group of basaltic and andesitic lava flows and endogenous domes that overlie 
the silt mantle on the Imuruk volcanics and that are overlain locally by the Camille and Lost Jim lava flows. The originally smooth surfaces of pahoehoe flows of the Gosling volcanics have been brecciated by frost riving to depths of at least 10 feet in most places, and the flows now consist of higher areas of openwork rubble interspersed with low-lying areas of rubble mixed with silt. Progressively younger flows have progressively larger proportions of areas underlain by openwork rubble and progressively smaller areas underlain by rubble mixed with-silt. The formation is named for Gosling Cone, located at the source vent of a typical lava flow of the Gosling volcanics (pl. 1).

A lava flow of the Gosling volcanics has invaded a morainal loop of Nome River (Illinoian) age in the valley of Minnie Creek (pl. 1); areas of openwork rubble on this flow are relatively small, and therefore it is considered to be one of the oldest members of the formation. Lava flows of the Gosling volcanics are observed to transgress the silt mantle on the Imuruk volcanics in many areas; the relationships are especially clear at the margin of the "island" of Imuruk volcanics enclosed by a lava flow of the Gosling volcanics 3 miles east of Sandy Lake (pl. 1). One of the youngest lava flows assigned to the Gosling volcanics has invaded a canyon that had been carved by the Kugruk River in lava flows of the Imuruk and Kugruk volcanics (fig. 9).

DISTRIBUTION

The Gosling volcanics cover extensive areas between the southeast end of:Imuruk Lake; the head of the Kugruk Canyon, the head of the Koyuk River, and the headwaters of the Kuzitrin River (pl. 1). The Lost Jim and Camille lava flows are probably underlain by a flow of the Gosling volcanics throughout much of their extent, for small tongues of Gosling volcanics appear from beneath the edges of the Lost Jim and Camille flows in many places. Other patches of Gosling volcanics are found on Hoodoo Hill, on the southwest: flank of Kettle Dome, at Virginia Butte, and at Skeleton Butte.

In most places the Gosling volcanics range from 10 to 50 feet. in thickness. Thicknesses of 150 to 300 feet are probably attained near some of the source vents.

\section{ERUPTIVE HABIT}

The Gosling volcanics include several endogenous domes and short, thick steep-fronted flows of block lava; several an flows; and extensive areas of pahoehoe flows. Most of the flows were emitted from widely scattered short-lived vents. Activity of single vents 
over more extended periods is recorded, however, at Twin Calderas, Hoodoo Hill, Virginia Butte, and Skeleton Butte.

The pahoehoe flows range in thickness from 5 to 20 feet at their fronts but probably attain considerably greater thicknesses near their source vents. Small agglomerate cones, commonly craterless and ranging in height from 10 to 30 feet, mark some of the source vents; other vents lack pyroclastic deposits at the surface and can be identified only by the fact that they lie somewhere within broad summit areas on individual lava flows.

The Twin Calderas indent the summit of a broad lava dome at the site of a relatively long-lived vent. The dome stands 400 feet above lowlands to the south, west, and northeast. The two collapse calderas are 1,700 and 2,500 feet in diameter and 50 and 120 feet deep. Flat-floored sector grabens extend north from the northeast caldera and south from the southwest caldera (fig. 11). The caldera walls lie at the angle of repose for coarse rubble, and little solid bedrock can be seen. Exposures in the southwest caldera show, however, that the walls transect the smooth-surfaced pahoehoe-lava flow forming the surface of the lava dome. Near the top of the wall, the lava flow is composed of flow units 0.2 to 0.5 foot thick separated by thin zones of agglomerate. At greater depth the wall exposes flow units 2 to 6 feet thick.

Hoodoo Hill is the site of another relatively long-lived vent, though the hill owes part of its present height to the fact that it is a horst bounded by normal faults cutting lava flows of the Gosling and Imuruk volcanics (fig. 1). An aa flow and a shattered endogenous dome assigned to the Gosling volcanics compose the upper part of Hoodoo Hill. The an flow is at least 50 feet thick in exposures in the fault scarp on the south slope. At the summit of the hill several hundred large boulders are perched in an area about 500 feet in diameter; the largest boulder is about 20 feet high and stands entirely above the soil surface. The boulders consist of exceptionally coarse holocrystalline olivine andesite containing visible angular intercrystal voids and lacking rounded vesicles. The boulder patch is interpreted to be the remnant of an endogenous dome that was extruded as almost completely crystallized lava and was explosively shattered in the closing phase of volcanic activity at Hoodoo Hill.

Gosling volcanics at Virginia Butte consist of an early aa lava flow, a short thick flow of late block lava that represents an endogenous dome that expanded slightly beyond the limits of the vent, 


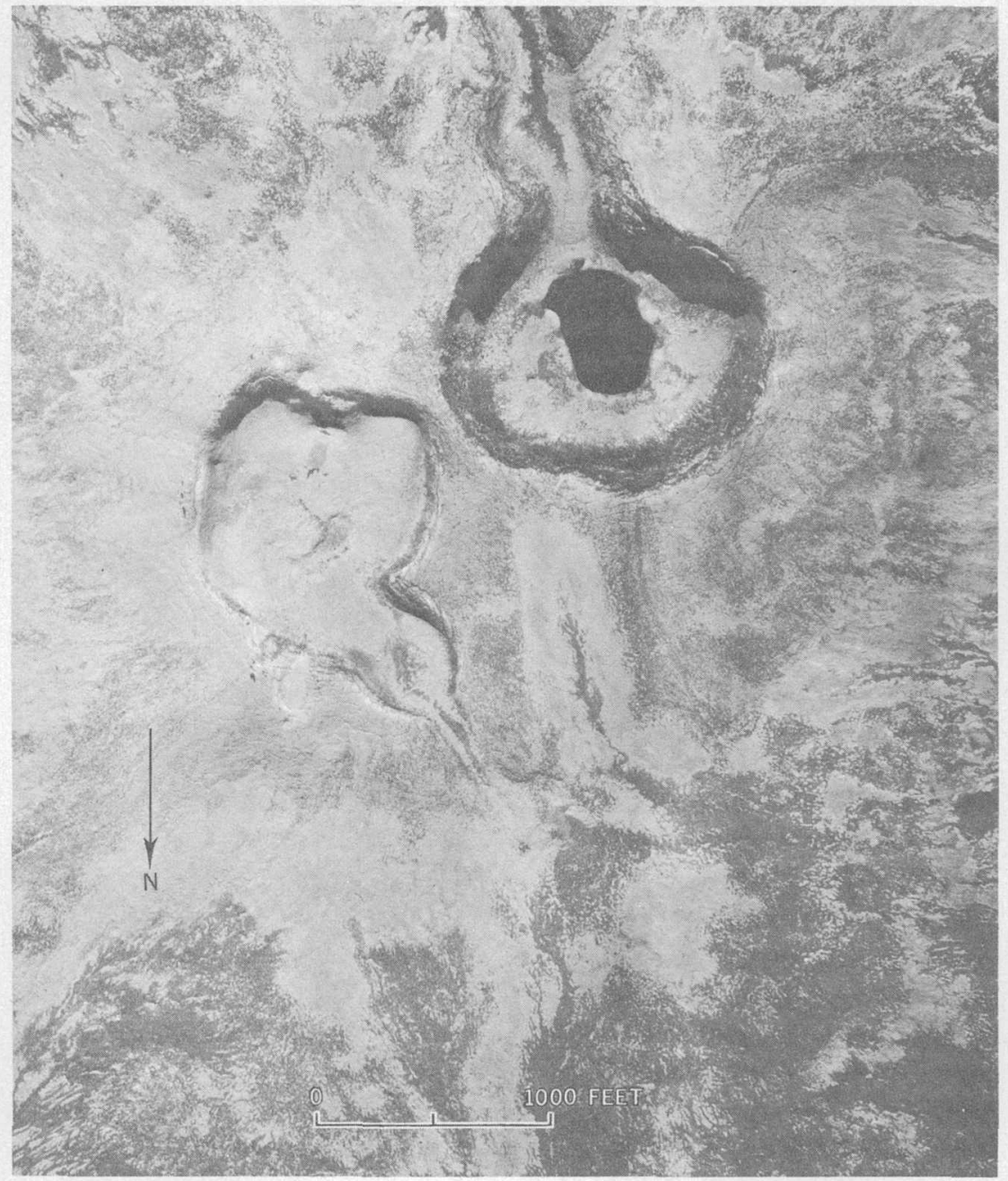

FIGURF 11.-Aerial photograph showing Twin Calderas and surrounding lava dome of Gosling volcanics. Vertical aerial photograph taken October 2, 1946, by U.S. Army Air Force. Approximate scale, 1:12,000.

and remnants of an agglomerate cone (fig. 12). Each of these units contains abundant inclusions of dunite and of granitic rock. The aa flow extends diagonally down the northeast flank of a ridge of quartz monzonite extending from Virginia Butte to the Asses Ears; gentle steplike escarpments that may be fault scarps extend almost normal to the long axis of the flow. The agglomerate cone is in part perched on the aa flow and appears to be younger than the flow. The internal structure of the cone, seen in a nivation niche at the 
north flank of the butte, consists of layers of agglomerate laced by sills and dikes, 1 to 10 feet thick, of dense nonvesicular basalt displaying well-developed columnar jointing. Virginia Butte, itself, is a steep-sided flat-topped endogenous dome about 100 feet thick of dense nonvesicular basalt that has breached the low agglomerate cone. The sides are mantled in most places by rubble, but solid rock can be seen in a few places.
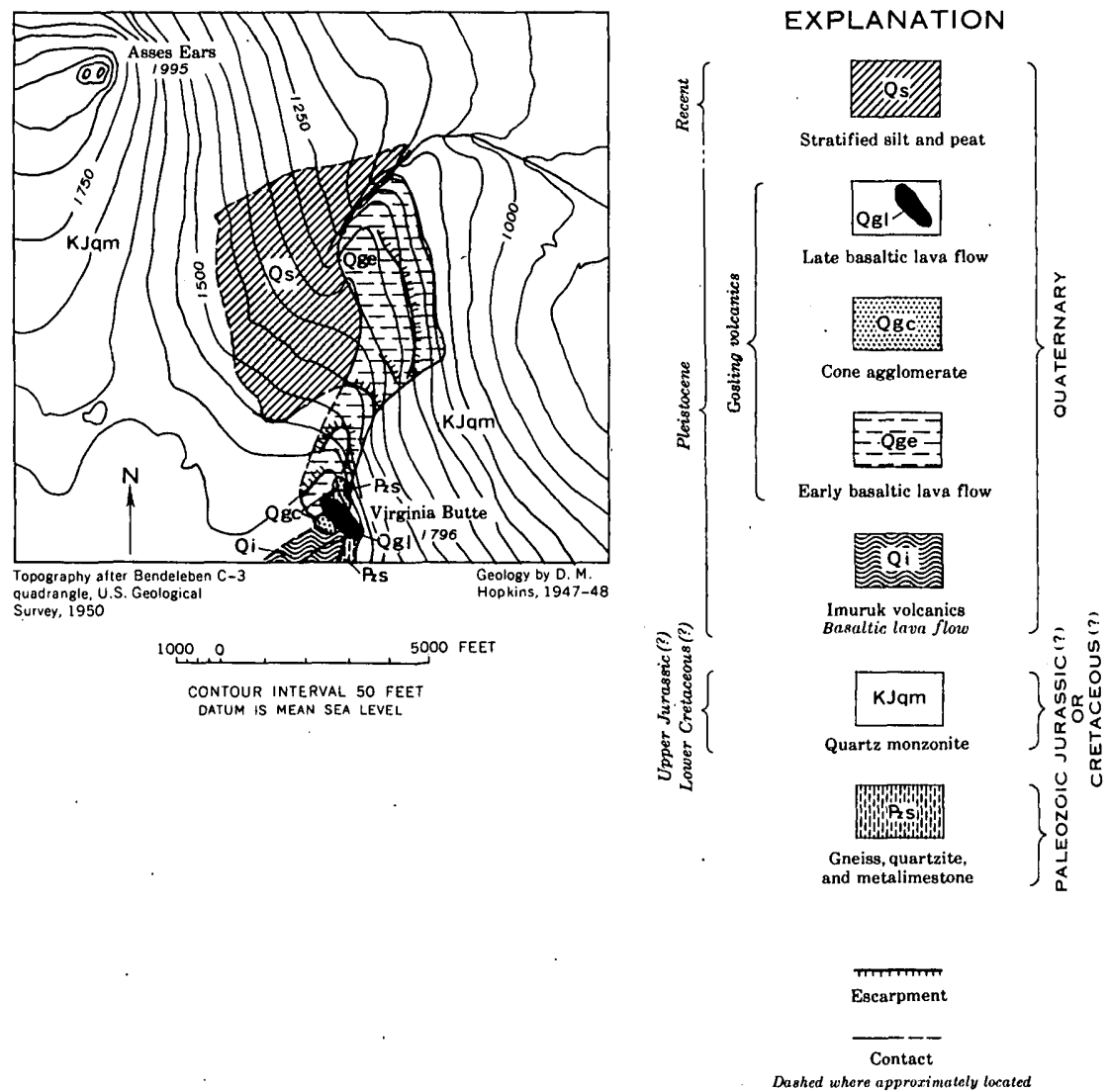

Figure 12.-Geologic map of Virginia Butte and vicinity.

Skeleton Butte is either a stubby steep-side flow or an endogenous dome, about 1,000 feet long and 50 feet thick, consisting of dense nonvesicular basalt of the Gosling volcanics that surmounts a gently sloping conical surface underlain by a flow assigned to the Imuruk volcanics. The summit and slopes of Skeleton Butte are composed of angular blocks ranging from a few inches to 20 feet in diameter. An apron of frost-moved boulders extends about 100 feet in all directions from the base of the butte. 
Most surfaces underlain by flows of the Gosling volcanics consist of undulating ridges and swales having a local relief of 10 to 50 feet. The ridges consist of openwork rubble composed of angular boulders, as much as 15 feet in largest dimension, perched in unstable positions (fig. 13A). The swales are underlain by basaltic boulders embedded in sandy silt and bear a nearly continuous cover of sedges, heaths, willows, and dwarf-birch shrubs. The areas of openwork rubble have a complete cover of lichens but lack plants of a higher order.

Except for a few masses of less fractured rock that are readily recognizable as pressure ridges ${ }^{8}$ (left background, fig. $13 \mathrm{~A}$ ), the assemblage of ridges and swales appears patternless to the ground observer picking his way across the difficult terrain. From the air, however, the topography is clearly seen to include systems of lava platforms, pressure ridges, and collapse depressions comparable to those on the Lost Jim lava flow (fig. 14) but modified slightly by the small movements resulting from deep frost riving. The minor extent of modification of the surface is further demonstrated by the ubiquitous exposed boulders bearing filamented or ropy pahoehoe surfaces on one face.

The Kuzitrin, Koyuk, and Kugruk Rivers cross the Gosling volcanics in confined channels. Elsewhere, surface streams are lacking, and drainage is accomplished entirely by subsurface percolation through the openwork rubble. Subsurface drainage evidently is concentrated largely in minor valleys buried beneath the Gosling volcanics. Three miles east of Gosling Cone, a low-lying area of silt-mantled Imuruk volcanics is entirely surrounded by lava flows of the Gosling volcanics (pl. 1). A shallow valley on the surface of the Imuruk volcanics contains a small clear stream that emerges from the base of the Gosling volcanics at one end of the island and disappears again into Gosling volcanics at the other end.

AGE

The Gosling volcanics are probably of Sangamon and Wisconsin age. One of the oldest flows in the formation has invaded the morainal loop of Nome River (Illinoian?) age on Minnie Creek and is therefore of post-Illinoian age. Appreciable quantities of windblown silt have accumulated in low areas on all flows assigned to the Gosling volcanics, and thus all the flows were probably extruded prior to the end of the Salmon Lake (Wisconsin) glaciation.

\footnotetext{
8 Pressure ridges are elongate upbowings of the crust of lava flows, apparently due to compressive forces imparted by the viscous drag of slowly moving subcrustal lava (Wentworth and Maqdonald, 1953, p. 49-50).
} 
A consideration of the character and distribution of the frostrived surfaces of the pahoehoe flows assigned to the Gosling volcanics adds further evidence that the Gosling volcanics were extruded during or prior to the last major glacial interval. The lava platforms and pressure ridges that characterize the pahoehoe flows of the Gosling volcanics must once have borne smooth pavementlike surfaces, as do similar features on the Lost Jim lava flow. However, the frost riving that disrupted the smooth surfaces took place in the remote past. The uppermost boulders in the rubble bear a complete cover of gray-green and black lichens on their upper surfaces and of yellow and red lichens on their under surfaces. Recently rotated or overturned boulders, easily recognized by the yellow and red lichens on exposed surfaces, are rare; the few that can be found can be assumed to have been overturned under the feet of reindeer or other large animals. The rubble evidently has not been disturbed by frost riving for many decades.

I shall show later that frost riving has never affected well-drained sites on the Lost Jim flow, such as lava platforms and pressure ridges, and therefore that frost riving has not been effective in welldrained sites for several hundred years. A climate considerably different from any that has prevailed in the Imuruk Lake area in recent centuries must be invoked to account for the thorough brecciation of the surfaces of pahoehoe flows of the Gosling volcanics.

Rocks are split by frost action when they are subjected to prolonged subfreezing temperatures while fractures and other small openings are filled with water. Under the present climate this condition is not satisfied in most places on the Gosling volcanics, the Camille flow, and the Lost Jim flow. Ice and snow persist in the interstices of the rubble a few feet below the surface during early summer, and shallow lakes are held in low areas on the surfaces of the flows. However, thawing occurs to depths of at least 10 feet later in the summer, and by August no snow, ice, or water can be seen among the boulders. Most of the lakes have drained, and their beds are dry.: Consequently, little moisture is available for frost riving during the critical autumn freezing season.

If 'summers' were shorter or cooler conditions would be more favorable for frost riving. For example, snowbanks would persist in sheltered niches on the surfaces of the flows; thawing would extend to shallower depths in bedrock or rubble; interstitial snow and ice would remain nearly' everywhere in openings a few feet below the surface; subsurface drainage would be impeded, and shallow lakes on the flows would last throughout the summer; melt water and 
ground water from these sources would furnish a continuing supply of moisture during the fall freezing season and would lead to active frost riving throughout the extent of exposed lava flows.

Periods of intense frost riving can be equated with periods of glaciation in nearby mountainous areas, for a shorter summer thawing season would greatly reduce ablation losses on mountain glaciers. The general lack of frost brecciation at the surface of the Lost Jim flow indicates that it is younger than the last major glaciation of Seward Peninsula. The limited disturbance of the Camille flow indicates that it has been exposed to the climate of a glacial interval for a limited time. The thorough disruption of the surfaces of flows of the Gosling volcanics indicates that they have undergone intense frost riving during one or more prolonged glacial intervals and confirms the stratigraphic evidence for a Sangamon and Wisconsin age.

\section{CAMILLE LAVA FLOW}

LITHOLOGY AND STRATIGRAPHY

The name Camille lava flow is proposed for a large pahoehoe lava flow, only slightly disturbed by frost riving, that is exposed discontinuously from Camille Cone 24 miles westward to the junction of Goose Creek and the Noxapaga River (pl. 1): The lava flow is named for Camille Cone; an agglomerate cone at the source vent. This is also the type locality.

The Camille flow overlies flows of the Gosling and Imuruk volcanics and is overlain between Lava Lake and Camille Cone by the Lost Jim lava flow. The part of the Camille flow that invaded the valleys of Andesite Creek and the Noxapaga River is confined to a meandering channel in the surface of a stream terrace that stands about 4 feet above the present flood plain of the Noxapaga River; the flow evidently was emplaced at a time when the 4 -foot terrace formed the flood plain. Deposits of windblown silt a few inches thick are found on a few flat surfaces that have been relatively little rived by frost.

A lava cone about 100 feet high and a mile in diameter has accumulated over the source vent at Camille Cone; elsewhere, the Camille flow is generaly less than 25 feet thick.

\section{ERUPTIVE HABIT}

The Camille lava flow is a relatively smooth pahoehoe flow. Surface relief is low compared to the Lost Jim lava flow (generally less than 5 feet and nowhere exceeding 20 feet) and much of the flow is flat and featureless (fig. 14). Pressure ridges and collapse 
depressions are small and scarce. Small hornitos ${ }^{9}$ are common near the source vent.

The lava cone at the source vent is surmounted by Camille Cone, a welded agglomerate cone about 65 . feet high; the crater, about 60 feet in diameter, is filled to the rim with loose scoria.

WEATHERING AND EROSION

The surface of the Camille flow everywhere consists of openwork rubble and hence bears almost no vegetation except lichens; frost riving has extended to depths as great as 5 feet, but the total disturbance of the surface has been small compared to the thorough disruption that frost riving has accomplished on the surfaces of pahoehoe flows of the Gosling volcanics (fig. 13).

Riving has proceeded chiefly along incipient fractures developed during the emplacement and cooling of the flow. Most of the surface blocks are polyhedral, bounded by polygonal cooling fractures of the initial columnar jointing and ranging in diameter from 0.5 foot to 6 feet. The average size of the blocks differs considerably from one area of the flow to another.

Individual blocks at the surface are tilted slightly from their original positions and wedged a few inches from adjoining blocks. The surface thus appears "exploded"; it resembles a jigsaw puzzle that has been disrupted by vibration so that individual pieces are spread apart but retain their original relative spatial relationships to one another (fig. 13B). The initial surface could be reconstructed by simply tilting the blocks a few inches back to their original positions.

On a.larger scale, initial microrelief on the surface of the flow remains easily recognizable. Pressure ridges, hornitos, and collapse depressions retain their initial forms, softened only slightly by the readjustments among blocks resulting from frost riving (fig. 14).

Blocks on the surface of the Camille flow everywhere bear a heavy cover of crustose lichens, demonstrating that disturbance by frost riving has ceased. Higher order plants are found only on the small local patches of windblown silt and on an area near Camille Cone where a thin sheet of ash blankets the surface.

The Noxapaga River in its meandering course between Andesite Creek and Goose Creek twice crosses the Camille flow in an open subaerial channel. Slow sweeping meanders alternate with short boulder-choked rapids where the river crosses or impinges upon the

\footnotetext{
9 Hornitos are mounds of driblet or spatter built on the surface of a lava flow by the gradual accumulation of clots of lava ejected through an opening in the roof of an - underlying lava tube (Wentworth and Macdonald, 1953, p. 52).
} 

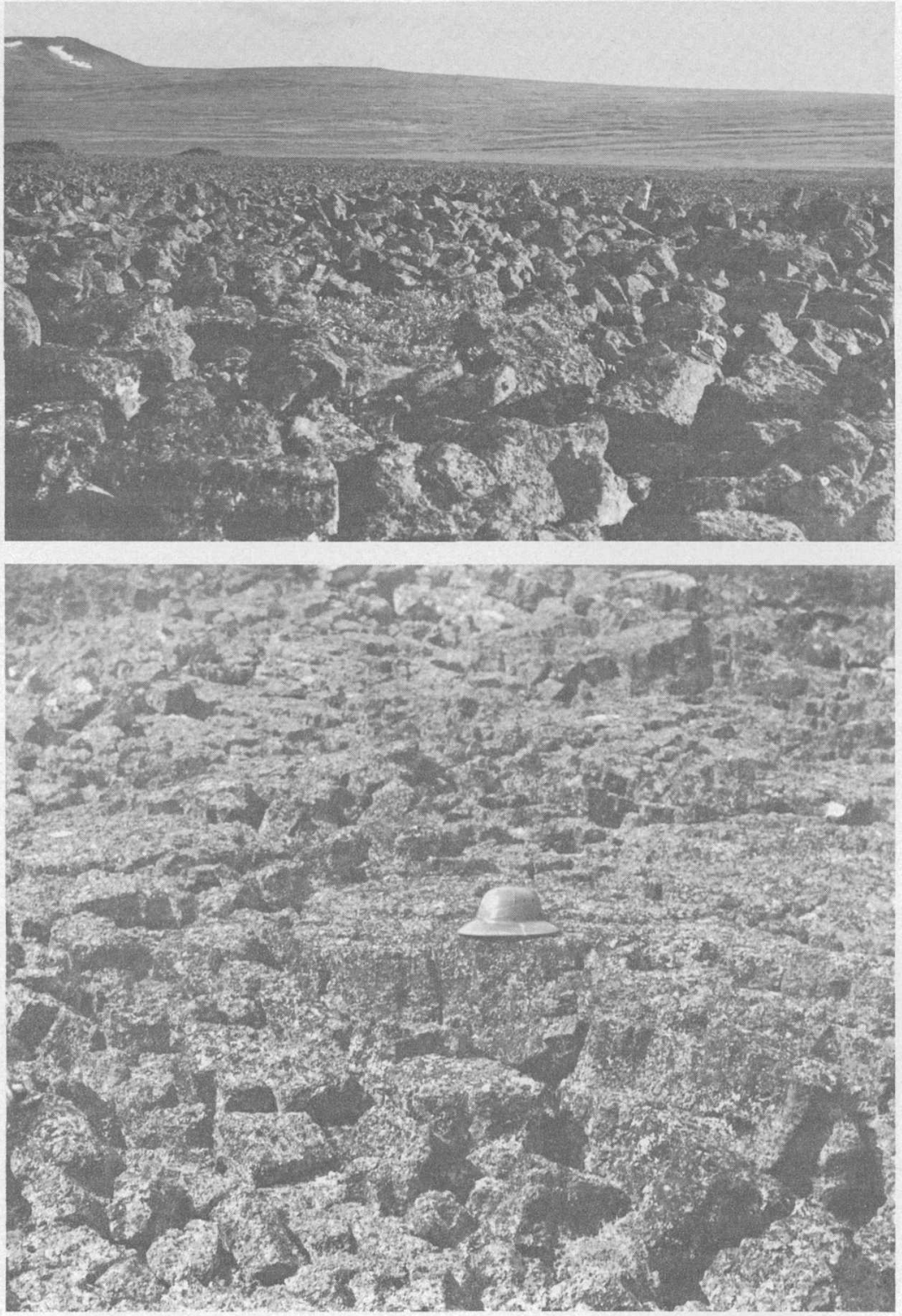

Figure 13.-Comparison between the surface of a lava flow of the Gosling voloanics and the surface of the Camille lava flow. $A$ (above), Frost-rived rubble at surface of a basaltic lava flow of the Gosling volcanics near west end of Kuzitrin Lake. Low hillocks in left distance are small frost-brecciated pressure ridges. Dog at right center gives scale. $B$ (below), Frost-rived surface of the Camille flow about a mile south of Lava Lake. Note remnants of relatively undisturbed surface around hat. 


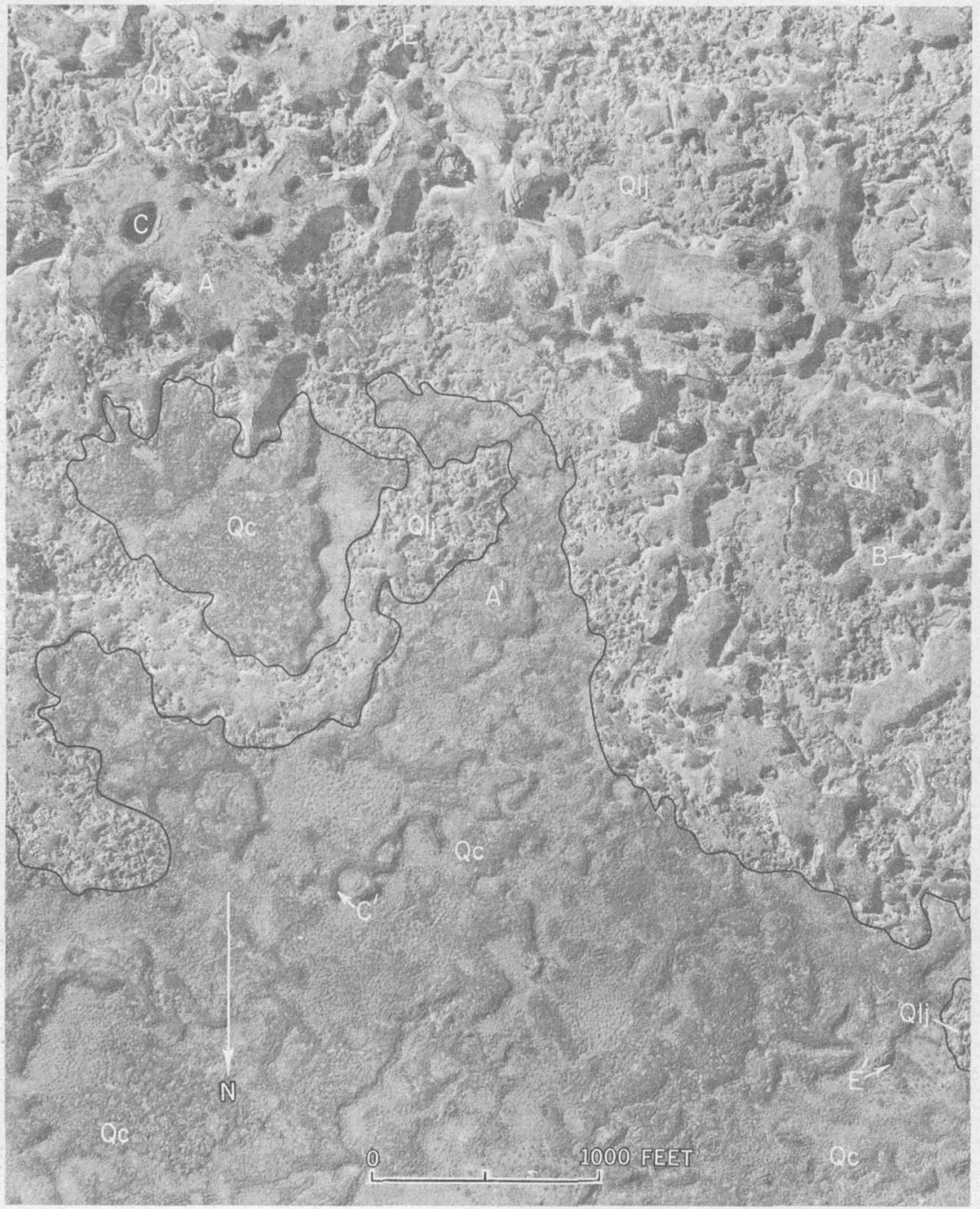

Figure 14.-Comparison between the surfaces of the Lost Jim lava flow (Qij) and the Camille lava flow (Qc) in an area 41\% miles east of Lava Lake Lost Jim flow (upper half of photograph) is fresh and unaffected by frost riving. Lava platforms (A) probably represent domes and arched areas over distributary lava tubes. Note lines of small pits marking course of a small lava tube at right of $B$ and larger collapse sink at $C$. Pressure ridges (E) probably mark margins of a collapsed lava dome. The surface of the Camille flow (lower part of photograph) has been thoroughly brecciated by frost riving and consists of slightly rotated blocks that give rise to finely stippled appearance on this aerial photograph. Despite disturbance of surface, slightly softened outlines of lava platforms $\left(A^{\prime}\right)$, collapse sinks $\left(C^{\prime}\right)$, and pressure ridges $\left(E^{\prime}\right)$ are readily recognized. Vertical aerial photograph taken October 2, 1946, by U.S. Army Air Force. 
lava flow. The pattern suggests that the river has been superimposed upon the lava flow from a cover of alluvium, but the stratigraphic and geomorphic relations clearly indicate that this is not true. No remnant of a former alluvial cover can be found; instead, the flow displays the usual pahoehoe microrelief modified only slightly by frost action and not at all by stream erosion.

Large streams percolate through the Lost Jim lava flow in several places without ponding on the upstream side. Evidently the present course of the Noxapaga River across the Camille flow has developed through the integration of such streams. The rapids have formed in places where the river originally percolated through crevices and fractures in the lava flow. The abundance of moisture at these sites probably resulted in accelerated frost riving; the finer particles produced by riving were removed by water moving through the larger fractures. Rapid frost riving and elutriation of the resulting finer particles, continued through a period of several thousand years, have produced a subaerial channel wherever the Noxapaga River crosses the Camille flow.

Except for the Noxapaga River, the Camille flow contains no surface streams; drainage is entirely subsurface. Small streams emerge from the base of the flow in several places, indicating that subsurface drainage is concentrated chiefly in minor buried valleys in the silt mantle on the underlying Imuruk volcanics.

$\mathbf{A G E}$

The Camille lava flow is probably of late Wisconsin age. The brecciated condition of the surface indicates that the flow has been exposed to the severe climate of the last major glacial interval on Seward Peninsula, but the period of exposure was brief compared with the long period during which the intensely disturbed surfaces of pahoehoe flows of the Gosling volcanics must have been exposed. The small thickness of windblown silt on the Camille flow also suggests that it was emplaced late in the last major glacial interval.

\section{LOST JM LAVA FLOW}

IITHOLOGY AND STRATIGRAPHY

The name Lost Jim lava flow is proposed for the youngest lava flow in the Imuruk Lake area-a large pahoehoe lava flow, virtually undisturbed by frost riving, that extends from its source at Lost Jim Cone northward to the shore of Imuruk Lake, westward to the shore of Lava Lake, and southwestward to the Kuzitrin River (pl. 1, fig. 15). The lava flow is named for Lost Jim Cone, an unusually large cinder cone at the source vent. Lost Jim Cone is the type locality. 


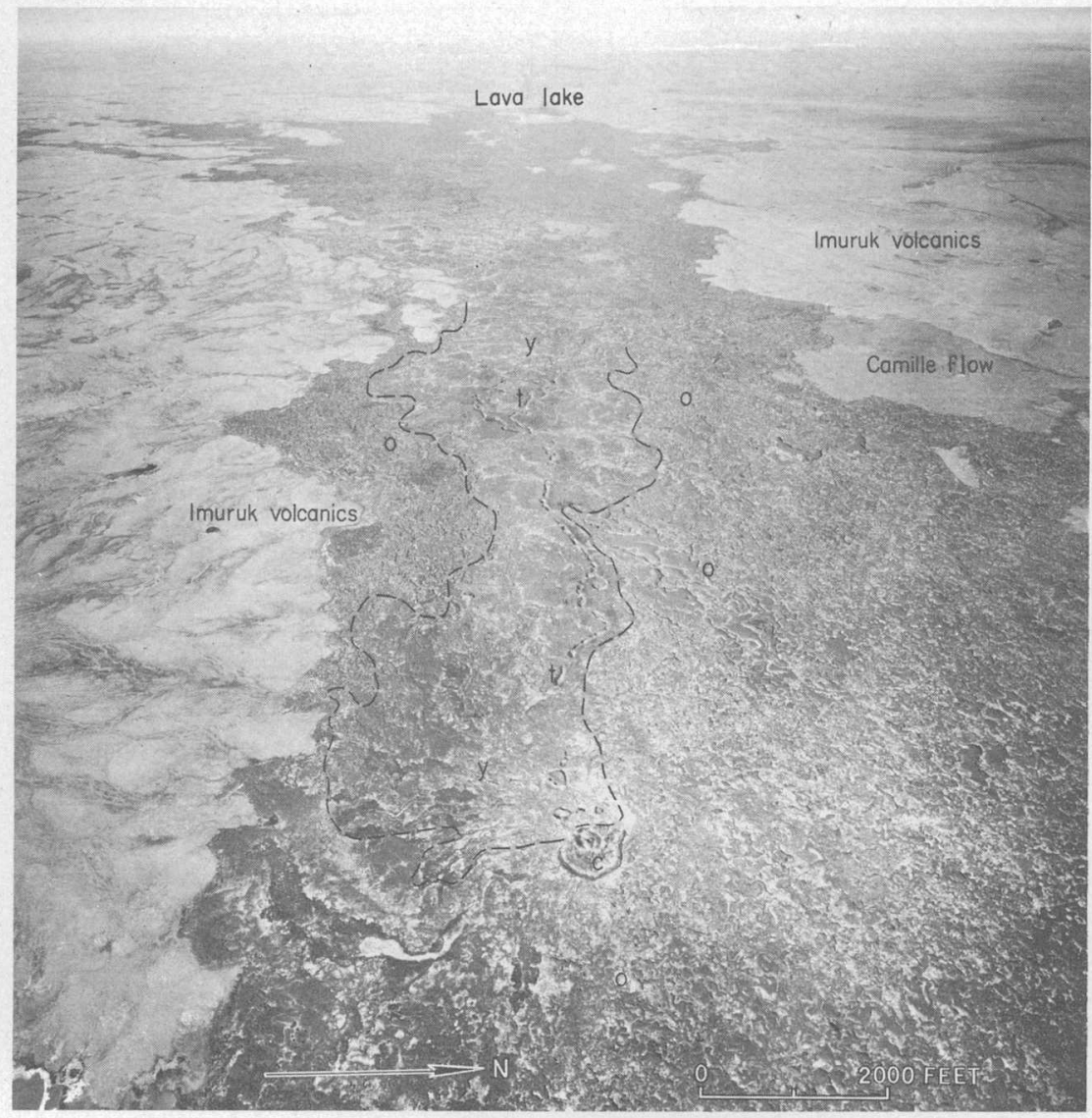

Figure 15.-General view of the Lost Jim lava flow, looking westward from east edge of the flow. Flow originated at source vent beneath Lost Jim Cone (c). Areas beyond the dashed line $(o)$ represent the rugged older parts of the Lost Jim flow, and areas within the dashed line $(y)$ represent the smoother younger parts. Course of great lava tube can be traced westward by line of deep collapse pits $(t)$. Oblique aerial photograph taken Octoger 2, 1946, by U.S. Army Air Force. Scale is for foreground only.

The Lost Jim lava flow rests upon all of the older volcanic formations, with the possible exception of the Kugruk volcanies. Flat areas on the western part of the flow bear a discontinuous veneer of windblown silt an inch or two thick.

\section{DISTRIBUTION}

The Lost Jim flow extends a maximum of 21.5 miles westward from the source cone and covers an area of about 88 square miles. Most of the flow lies in a broad belt between Lost Jim Cone and Lava Lake. Narrow tongues of lava have invaded the valleys of Andesite Creek and minor tributaries of the Kuzitrin River. Another tongue extends northward from the source cone down a shal- 
low valley to Imuruk Lake, where a large lava delta has been built at the south shore. Much of the western part of the flow was fed through a great lava tube of complex history, which extends at least 12 miles west from Lost Jim Cone (fig. 15).

The flow varies greatly in thickness. The narrow tongue that extends 1.7 miles down the valley of Andesite Creek near Lava Lake is nowhere thicker than 10 feet; lava tongues confined in other constricted valleys are generally 20 to 30 feet thick. The lava delta on the south shore of Imuruk Lake contains at least 50 feet of lava. The topography of the main body of the flow suggests that thicknesses as great as 100 feet are common and that the flow is about 150 feet thick near Lost Jim Cone. The average thickness of the flow probably exceeds 50 feet, and the flow thus contains between 0.8 and 1.0 cubic mile of lava.

\section{ERUPTIVE HABIT}

The Lost Jim lava flow is a typical pahoehoe lava flow, similar in many respects to the McCartys flow of New Mexico (Nichols, 1946) and to flows of Recent age in Hawaii (Wentworth and Macdonald, 1953). The major surface relief of the older part of the Lost Jim flow consists of pressure ridges and flat-topped lava platforms intermingled with collapse sinks and broad hummocky depressions (fig. 14). Local relief on the flow ranges from 10 to 60 feet.

Structures - of the Lost Jim flow at Lost Jim Cone and elsewhere indicate that the eruption of the flow can be subdivided into early and late intense phases, possibly separated by a period of relative quiescence (Hopkins, 1956). The older and younger parts of the flow differ in the character of their surface relief and can be distinguished readily in many places where they are in contact (fig. 15).

Lost Jim Cone, a cinder cone of exceptional size and form for the Imuruk Lake area is built over the source vent of the Lost Jim flow (fig. 15). The cone, about 100 feet high, is indented by a wellformed crater, 100 feet in diameter and 40 feet deep, containing a small lake. A craterless adventive (subsidiary) cone, 60 feet high, at the west base of Lost Jim Cone probably marks the principal source of lava that passed westward through the great lava tube. Both cones are composed of loose angular scoria, $1 / 2$ inch to 2 inches in diameter. No bombs with fluidal textures or forms are present. Several hornitos, 10 to 20 feet high, stand at the base of the cone.

Flat surfaces within 500 feet of Lost Jim Cone bear a cover of pumiceous ash a few inches thick. The ash thins rapidly farther 
away, and no conspicuous accumulations are found more distant than half a mile from the source cone.

WEATHERING AND EROSION

Large areas of pavementlike surfaces of filamented pahoehoe ${ }^{10}$ and smaller areas of festooned pahoehoe, slab pahoehoe, and smoothsurfaced aa cover most of the Lost Jim flow; surfaces of these types are covered with lichens and are undisturbed by frost action. However, the surface of the flow has been thoroughly broken up by frost riving, and the lichen cover is incomplete or absent in depressions where water stands intermittently or continually and in some marginal areas where a thin sheet of lava rests on waterlogged silt mantling the Imuruk volcanics.

The Lost Jim flow contains no surface streams and almost no surface water. Throughout much of the flow, the water table lies 20 feet or more beneath the surface. Small clear streams flowing across "islands". of Imuruk volcanics within the Lost Jim flow and similar streams heading in areas of Imuruk volcanics and disappearing beneath the margins of the Lost Jim flow suggest, again, that subsurface drainage is concentrated chiefly in buried valleys in the silt mantle on the Imuruk volcanics. Minor tributaries of the Kuzitrin River, whose valleys have been invaded by tongues of the Lost Jim flow, meander "through" the lava in several places. Small lakes are dammed at the upstream margins of the lava tongue in a few places, but more commonly the streams percolate through the flow. without ponding.

AGE

The lack of disturbance by frost riving, except in wet areas, indicates that the Lost Jim lava flow was extruded after the last major glacial interval on Seward Peninsula. No eruptions have been recorded on Seward Peninsula since the arrival of Europeans in the 18th century nor have the Eskimos of Deering and Cape Espenberg, on the coast of Kotzebue Sound, any knowledge or legend concerning a volcanic eruption (John Cross, pilot, Deering, Alaska, oral communication, 1948). The Lost Jim lava flow is at least several hundred and possibly several thousand years old.

\section{BROWN-ASH - LAYER}

A thin layer of brown or pink volcanic ash (not shown on pl. 1) is exposed near the top of the older of the two groups of intermediate terraces at Imuruk Lake, in terraces adjoining Sandy Lake

10 The names used for surface textures of lava are those proposed by Wentworth and Macdonald (1953). 
and the cluster of small lakes in the valley of Andesite Creek 1 mile west of Lava Lake, and in the walls of thaw gullies cut in stratified peat and silt in an area bounded by Imuruk Lake, the Lost Jim lava flow, Andesite Creek, and the Noxapaga River. It is lacking in the younger intermediate terraces at Imuruk Lake and in low terraces at Lava Lake. The ash layer ranges from $1 / 2$ inch to 3 inches in thickness; it is generally overlain by $1 / 2$ foot to 3 feet of peat that has accumulated in place on the surface of the ash.

The brown or pink ash represents the only widespread sheet of pyroclastic material recognized in the Imuruk Lake area. It differs in grain size and color from the coarse pumice found near some recognized basaltic vents.

The brown or pink ash is similar in grain size but is less well sorted than windblown silt. The silt-sized fraction consists of abundant grains of brown glass, hypersthene, magnetite and other opaque minerals, less abundant grains of plagioclase and diopside, and a few grains of brown amphibole and olivine. ${ }^{11}$ The sand-sized fraction consists chiefly of mica and cylinders of limonite-cemented silt (probably casts of sedge roots) but includes a few grains of plagioclase and quartz.

The location of the vent from which the ash was erupted remains unknown. The presence of the ash layer in the older group of the intermediate terraces at Imuruk Lake and its absence in the younger group suggest that the eruption took place at some time during the Wisconsin glacial interval and thus that it is contemporaneous with either the Gosling volcanics or the Camille lava flow.

\section{PETRology AND PETRography}

Thirty-two thin sections of volcanic rocks from the Imuruk Lake area were examined by the late Joan P. Hopkins and me. These included 16 sections of olivine andesite and basalt, 2 of hypersthene andesite, 2 of pilotaxitic andesite, and 12 of inclusion-bearing basalt and andesite. The modal composition was estimated visually; no Rosiwal analyses were attempted. The composition of feldspars was determined mainly by measuring maximum extinction angles on albite twinning; composition of feldspar and olivine grains from a few specimens were determined by using index liquids. The average composition of the modal feldspar is used to distinguish between basalt and andesite in the discussion that follows. Rocks in which the dominant feldspar is labradorite are termed "basalt"; those in which andesine predominates are termed "andesite."

\footnotetext{
11 Minerals in the silt fraction were determined by Dorothy Carroll, U.S. Geological Survey.
} 
Most of the volcanic rocks of the Imuruk Lake area have compositions near the boundary between basalt and andesite. Andesite predominates; but basalt is common. There are minor differences in composition and mineralogy between different lava flows in each volcanic formation, but the lava flows show no systematic variation in composition with age.

Most flows are free of inclusions, but the olivine that is abundant in a few seemingly inclusion-free flows may be derived largely from disintegrated dunite inclusions. Several flows, endogenous domes, and possible intrusives, distributed in a northwest-trending belt extending from Blueberry. Dome to the ridge between Trail Creek and Divide Creek (pl. 1), contain abundant angular inclusions of dunite, magnetite, granitic rock, and schist. . Aside from an exceptionally high olivine and opacite content in the inclusion-rich flows, there appears to be no correlation between the composition of the host rock and the presence or absence of inclusions.

The textures of the flow rocks generally are intergranular, but intersertal and hyalo-ophitic textures are common. Pilotaxitic textures were observed in a few flows. Many flows are holocrystalline; glass is only a minor constituent in most others, rarely comprising more than 3 percent of the volume of the rock. The Lost Jim lava flow is exceptionally rich in glass, containing as much as 30 percent at the surface and 20 percent at a depth of 25 feet.

\section{OLIVINE ANDESITE AND BASALT}

Olivine andesite and basalt are the predominant rock types among the late Cenozoic volcanic rocks of the Imuruk Lake area. They can probably be assumed to represent the primitive magma from which the less common volcanic rock types evolved by differentiation or contamination. Table 2 presents the chemical analysis and the normative minerals of a specimen of olivine basalt collected on the east wall of the Inmachuk River Valley just north of the mapped area of plate 1 .

Modal plagioclase constitutes 40 to 60 percent of the total volume of the olivine andesite and basalt. Most of the feldspar occurs as microscopic grains, but sparse plagioclase phenocrysts are common. Anorthite content ranges from 28 to 84 percent and generally averages about 45 percent. The largest crystals reach lengths of $5 \mathrm{~mm}$, are euhedral, and locally enclose grains of all the other minerals in the rock. Large crystals commonly show faint normal zoning; in a few flows the larger grains show oscillatory zoning. 
TABLE 2.-Chemical analysis and normative minerals of an olivine basalt flow [Specimen $49 \mathrm{Ahp} 50$ collected from Imuruk volcanics on east wall of Inmachuk River Valley, 1 mile downstream from Casadepaga Gold Co. Analyst, W. J. Blake, Jr., U.S. Geol. Survey]

\begin{tabular}{|c|c|c|}
\hline Chemical analysis (percent) & Normative minerals (percent) & Composition of normative minerals \\
\hline $\begin{array}{lr}\mathrm{SiO}_{2} & 49.13 \\
\mathrm{Al}_{2} \mathrm{O}_{3} & 14.07 \\
\mathrm{Fe}_{2} \mathrm{O}_{3} & \end{array}$ & \multirow{2}{*}{ 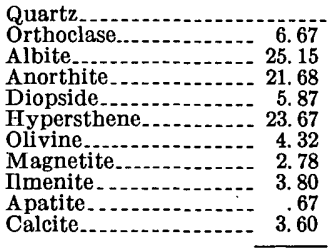 } & \multirow{4}{*}{$\begin{array}{l}\mathrm{Ab}_{38} \mathrm{An}_{81} \\
(\mathrm{CaO})_{50,},(\mathrm{MgO})_{33},(\mathrm{FeO})_{17}\left(\mathrm{SiO}_{2}\right)_{100} \\
\mathrm{Hy}_{66} \mathrm{En}_{34} \\
\mathrm{Fo}_{66} \mathrm{Fa}_{34}\end{array}$} \\
\hline 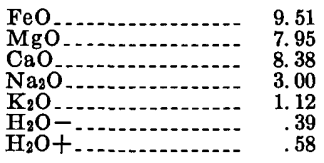 & & \\
\hline $\begin{array}{lr}\mathrm{TiO}_{2} & \\
\mathrm{CO}_{2} & \\
\mathrm{P}_{2} \mathrm{O}_{5} & .99 \\
\mathrm{MnO} & .18\end{array}$ & \multirow[t]{2}{*}{ Total _........ 98.21} & \\
\hline Total & & \\
\hline
\end{tabular}

Olivine constitutes 5 to 15 percent of the olivine andesite and basalt flows. Phenocrysts are nearly everywhere present, making up 3 to 5 percent of the rock. The larger grains reach lengths of about $1 \mathrm{~mm}$. They are well-formed, generally sharp edged euhedral grains showing no suggestion of resorption. Small grains are anhedral but also sharp edged. Large olivine grains commonly enclose smaller grains of augite, plagioclase, or glass. In one thin section, the larger olivine grains are in clots of 3 to 5 crystals, locally associated with augite. More commonly, the olivine grains are dispersed evenly throughout the rock. Refractive indices of olivine grains from two flows indicate a forsterite content of 75 percent.

Clinopyroxene constitutes 10 to 25 percent of the olivine andesite and basalt. The clinopyroxene generally occurs as irregular interstitial grains too small to identify precisely, but a few flows contain sparsely distributed euhedral grains of augite up to $0.3 \mathrm{~mm}$ long.

Opacite-probably magnetite or ilmenite-makes up about 5 percent of the olivine andesite and basalt flows. It forms instertitial blebs, rods, and skeletal crystals generally less than $0.5 \mathrm{~mm}$ but locally up to $1 \mathrm{~mm}$ long.

Needles of apatite 0.1 to $0.5 \mathrm{~mm}$ long are poikilitically enclosed in feldspar grains in a specimen from the endogenous dome at the summit of Hoodoo Hill.

Iddingsite replaces part of the olivine in nearly every specimen examined. The iddingsite occurs along cleavage planes and at the margins of large grains and completely replaces some small grains. A greenish alteration mineral-probably chrysotile-occurs along cleavage planes in olivine and feldspar in a few flows. 
Locally, vesicles are lined by glass. More commonly, they are partly lined by zones of exceptionally finely crystalline material. Vesicles in one of the older flows comprising Hoodoo Hill are adjoined by narrow zones of oligoclase $\left(\mathrm{Ab}_{85} \mathrm{An}_{15}\right)$, acmite(?), and fluorite(?). The presumed acmite consists of yellowish, nonpleochroic, bladed grains having extinction angles of $1^{\circ}$ to $3^{\circ}$.

Natrolite fills vesicles in basalt exposed about 1.6 miles east of Rhododendron Cone.

The Lost Jim flow is described separately, because it was possible to collect and compare a specimen of lava that had solidified at a depth of 25 feet near the center of the flow, with a specimen that had solidified within a few inches of the surface. The Lost Jim flow is composed throughout its extent of basalt containing small sparsely distributed olivine phenocrysts.

The surface lava is hyalo-ophitic, consisting of crystals of plagioclase, olivine, and clinopyroxene embedded in a continuous matrix of glass. Rounded vesicles are abundant. Some vesicles are lined with smooth glass, whereas others have microscopically rough interior surfaces consisting of projecting crystal faces of olivine and pyroxene.

Plagioclase in the surface lava consists of prismatic grains ranging from 0.1 to $0.5 \mathrm{~mm}$ and averaging $0.2 \mathrm{~mm}$ in length. The grains consist of 1 to 5 twins; a few of the larger grains contain inclusions of glass. The average anorthite content is 54 percent.

Olivine forms both phenocrysts and a groundmass mineral. The phenocrysts make up about 3 percent of the rock. They are euhedral and sharp edged and range from 1 to $1.5 \mathrm{~mm}$ in length. They contain scattered inclusions of glass. The olivine in the groundmass is less well formed; some grains are euhedral, but about half are irregular shreds. The groundmass olivine ranges from 0.04 to 0.08 $\mathrm{mm}$ in length.

Clinopyroxene is present in small quantities as minute shreds and laths that cannot be identified more precisely.

Glass makes up about 30 percent of the volume of the surface rock. It is black and opaque, presumably owing to dissolved or suspended iron oxide. No free opacite crystals were seen in the surface lava.

Lava from 25 feet beneath the surface differs in several respects from the surface lava. Rounded vesicles are rare, but there are scattered intercrystal voids as much as $2 \mathrm{~mm}$ in length. The texture is intersertal: the glass content is reduced to 20 percent and consists of shards 0.1 to $0.3 \mathrm{~mm}$ long (possibly filaments in cross section) dispersed among mineral grains of the groundmass. Visual 
inspection suggests that the reduction in glass content is compensated by about equal increases in the plagioclase, olivine, and pyroxene content and by the appearance of opaque crystallites.

Plagioclase in the deeper lava consists of sharp-edged, euhedral crystals composed of 4 to 10 twins. The grains range from 0.05 to $0.6 \mathrm{~mm}$ and average $0.4 \mathrm{~mm}$ in length. Some of the largest grains show inconspicuous normal zoning, and one crystal shows oscillatory zoning. The average anorthite content seems to be slightly lower than in the surface lava.

The olivine phenocrysts do not differ in size and abundance from those in the surface lava; however, many of the phenocrysts are embayed and rounded. No reaction rims were noted. Groundmass olivine crystals range from 0.1 to $0.3 \mathrm{~mm}$ in length. Tiny grains of red-brown to green-brown iddingsite are included in some olivine crystals.

Clinopyroxene, probably augite, is considerably larger and more abundant in the deeper lava than in the surface lava. It occurs in irregular shreds and laths 0.1 to $0.2 \mathrm{~mm}$ long, some of them conspicuously bent and warped. A few grains show hourglass zoning.

Acicular opacite (magnetite?) crystallites $0.3 \mathrm{~mm}$ long are scattered through the glass, and a few octahedra were noted in olivine grains. The glass is less opaque than the glass in the surface lava, and it is notable that opacite crystallites are surrounded by a leached zone of clear glass.

The differences between deep and surface lavas in the Lost Jim flow indicate that olivine phenocrysts crystallized at considerable depth before the flow was extruded and that they were out of equilibrium with the enclosing liquid after extrusion, despite the fact that small olivine grains (possibly of slightly different composition) continued to precipitate. Large feldspar grains, on the other hand, seem to have begun to crystallize just before extrusion and to have remained in equilibrium with the enclosing liquid after extrusion; older crystals continued to grow and new: crystals formed in the slowly cooling lava. Nearly all the pyroxene was precipitated after extrusion. Precipitation of opacite and partial alteration of olivine to iddingsite took place entirely after extrusion, in slowly cooling lava, for both opacite and iddingsite are absent in the quenched surface lava.

\section{HYPERSTHENE ANDESITE}

Two hand specimens of hypersthene andesite were collected about a mile apart in an area of Imuruk volcanics east of Imuruk Lake (pl. 1). One specimen was collected along the Fairhaven Ditch approximately 1 mile east of Imuruk Lake, the other on the opposite 
side of the valley of the Kugruk River about a mile to the south. The specimens are closely similar and may represent a single flow. The two specimens are exceptionally rich in megascopic crystals, containing, respectively, 30 and 40 percent phenocrysts.

Plagioclase constitutes about 65 percent of the total rock by volume; phenocrysts, as much as $3 \mathrm{~mm}$ long, constitute about 15 percent of the rock. Most of the feldspar is sodic andesine.

Olivine makes up about 10 percent of the rock. It occurs chiefly as phenocrysts; however, small grains also are present in the groundmass. The crystals are round and embayed; most are surrounded by a reaction rim of augite. The forsterite content of the olivine is about 75 percent.

Hypersthene phenocrysts, 0.7 to $3.0 \mathrm{~mm}$ long, make up about 5 percent of the rock. No hypersthene is found in the groundmass. The large grains are subhedral laths, commonly surrounded by sharply defined reaction rims of augite. One large lath contains many small optically oriented grains of augite and is enclosed by a reaction rim of similarly oriented augite grains.

Augite constitutes about 15 percent of the rock. It is chiefly in the groundmass and in reaction rims, but also forms phenocrysts as much as $1 \mathrm{~mm}$ long.

Opacite grains make up about 5 percent of each specimen. Glass makes up about 10 percent of one specimen.

The exceptionally large content of megascopic grains indicates that the hypersthene andesite had reached a considerably more advanced stage of crystallization prior to extrusion than had the olivine andesite and basalt. Because crystallization proceeded far enough for the boundary between the olivine and hypersthene fields to be passed, the precipitation of hypersthene and partial resorption of older olivine resulted. As crystallization proceeded still farther, the residual liquid reacted with the hypersthene and partially replaced it with oriented masses of augite. Macdonald (1949, p. 66) suggests that similar mixtures of augite and hypersthene in a Hawaiian basalt resulted from unmixing of initial pigeonite grains. Macdonald's explanation probably cannot be applied to the hypersthene basalt of the Imuruk Lake area, however, for the pyroxene phenocrysts here seem to have formed before extrusion, at a depth where the precipitation of pigeonite would be extremely unlikely.

\section{PHOTAXITIC ANDESTTE}

The knob of Kugruk volcanics forming the summit of Kettle Dome (pl. 1) consists of andesite having a pronounced pilotaxitic structure. The inclusion-bearing upper flow of the Kugruk volcanics 
exposed in the canyon of the Kugruk River is mineralogically and texturally similar.

Plagioclase occurs as generally untwinned ragged grains too small to permit determination of their anorthite content. Olivine occurs as tiny, sparsely distributed phenocrysts and in the groundmass. Most olivine grains are embayed and partly resorbed. Clinopyroxene is represented by small microlites and irregular shreds. The opacite (magnetite?) occurs as small octahedra. The Kettle Dome exposure also contains scattered spherulitic masses of chrysotile (?) ; most or all of which represent devitrified glass.

\section{INCLUSION-BEARING ROCKS}

Volcanic rocks rich in inclusions are found at several localities in a northwest-trending belt extending from Blueberry Dome to the northern tributaries of Cottonwood Creek (pl: 1). Most of the inclusion-rich rocks, including those exposured at the summit of Blueberry Dome, the head of the Kugruk River canyon, the northeast shore of Imuruk Lake, the head of the canyon of Cottonwood Creek, and the ridge between Trail Creek and Divide Creek, are assigned to the Kugruk volcanics. The inclusion-bearing volcanic complex at Virginia Butte, however, is assigned to the Gosling volcanics because the rocks are not weathered, dissection is slight, initial minor topography is fairly well preserved, and little or no windblown silt mantles the surface.

The host rocks include several flows, a shallow-seated intrusive at the northeast shore of Imuruk Lake, volcanic necks and enclosing breccias in Cottonwood Creek canyon, and cone agglomerate at Virginia Butte. The rocks are intersertal basalt and pilotaxitic andesite.

\section{COMPOSITION}

The groundmass of the intersertal basalt consists of microlites of plagioclase and small irregular grains of olivine and opacite. Groundmass opacite is exceptionally abundant, commonly making up 10 to 15 percent of the total volume of the rock. Small grains of pyroxene are present in a few specimens.

Phenocrysts of plagioclase, olivine, and augite make up 25 to 50 percent of the inclusion-bearing rocks. The plagioclase phenocrysts are large euhedral grains rarely showing strong zoning; the anorthite content ranges from 50 to 65 percent. Olivine phenocrysts are generally rounded and: approximately equidimensional; euhedral grains are rare. A few thin sections contain angular, broken olivine grains. Refractive indices indicate an average forsterite content 
of about 84 percent. Prehnite and natrolite were identified in the vesicles of inclusion-bearing basalt at Virginia Butte.

The pilotaxitic andesite is fine grained. The groundmass consists of plagioclase, olivine, and magnetite(?). Phenocrysts of olivine constitute about 10 percent of the rock. The feldspars range in anorthite content from 45 to 52 percent.

Inclusions of several types occur together in all the inclusionbearing volcanics. The most conspicuous and abundant inclusions are composed of dunite. Fragments of granitic rock also are present in nearly all inclusion-bearing rocks. In addition, large masses. of lustrous opacite (chrome spinel?) and large single crystals of oligoclase and orthoclase are found in the Kugruk River canyon and at the northeast shore of Imuruk Lake. Inclusions of vein quartz and schist are abundant in the volcanic necks in the canyon of Cottonwood Creek. Abundant groundmass carbonate in the central endogenous dome at Virginia Butte is probably derived from reworked marble inclusions.

The dunite inclusions are angular or rounded masses of olivine as much as 3 inches across. The masses commonly are roughly rectangular or parallelpiped in outline, but some are discoidal. The texture is sugary and the color is dark green on fresh surfaces and red or light yellow-green on weathered surfaces. The larger inclusions are surrounded by rims, about $1 / 16$-inch wide, of darkbrown material that forms shallow grooves encircling the inclusions, because the material weathers more rapidly than the adjoining rocks.

In thin section, most of the dunite inclusions are seen to be composed entirely of angular anhedral olivine grains, ranging in forsterite content from 78 to 84 percent. Most inclusions are surrounded by reaction rims of magnetite(?).

A few inclusions consist of large grains of forsterite-rich olivine, chrome spinel,,$^{12}$ and orthopyroxene partly altered to clinopyroxene. An inclusion from Virginia Butte is surrounded by a thin reaction rim of serpentine containing small scattered grains of green garnet.

The rounded, reworked, and locally broken appearance of olivine phenocrysts in the host rocks suggests that many are foreignderived from thoroughly disintegrated inclusions.

Anhedral grains of opacite (chrome spinel?), as large as an inch across and characterized by conchoidal fracture and a high vitreous luster, are abundant in rocks at the head of the Kugruk River canyon and on the northeast shore of Imuruk Lake. An opacite octa-

12 Identitied by C. S. Ross (Ross, Foster, and Myers, 1954, p. 701). 
hedron a quarter of an inch across was seen in one thin section. The exceptionally high opacite content in the groundmass of most of the inclusion-bearing flows may result, in part, from the disintegration of opacite inclusions.

Irregular angular inclusions of granitic rock, generally less than half an inch across, are also abundant in nearly all the inclusionbearing rocks. The least altered granitic inclusions consist of plagioclase impregnated with small shreds of biotite. A thoroughly altered inclusion from Kugruk River canyon is rectangular in outline and nearly as fine grained as the enclosing andesite; it consists of untwinned equidimensional oligoclase grains and biotite and opacite grains showing a marked parallel orientation. The inclusion is crisscrossed with veinlets of orange-brown iddingsite. Grains of oligoclase, as much as an inch across, are present in the inclusion-bearing volcanics on the northeast shore of Imuruk Lake and in Kugruk River canyon, and small 'grains of oligoclase are conspicuous components of other inclusion-rich lavas. Most of the oligoclase grains are angular and broken, but a few grains are euhedral. A large grain of orthoclase was recognized in one specimen from the Kugruk River canyon.

Inclusions of schist and of vein quartz were seen only in specimens from the head of Cottonwood Creek and were not studied petrographically.

Disseminated carbonate grains make up nearly 5 percent of some specimens collected well above the level of nearby marble outcrops in the endogenous dome at Virginia Butte. Their topographic position seems to eliminate the possibility that the carbonate was introduced by ground water. Aside from local zeolites in some vesicles, there is little evidence of hydrothermal or deuteric activity as a possible source of carbonate. The carbonate is probably derived from marble inclusions.

\section{ORIGIN}

The lava flows containing granitic inclusions are found in areas that are probably underlain by the Kuzitrin Lake batholith, and the volcanic rocks containing inclusions of schist and vein quartz are found in an area underlain by schist. It is reasonable to assume that the granite, schist, and quartz inclusions are fragments torn from the walls of the passages through which the inclusion-bearing lava moved to the surface.

Four hypotheses may be considered for the origin of the ultramafic inclusions: 
1. Iike the granite and schist inclusions, they may represent fragments of the rock that lined the passages through which the volcanics reached the surface.

2. They may represent unmelted fragments of a primitive peridotite substratum, in accordance with the theory of Ross, Foster, and Myers (1954).

3. They may have originated as segregations of early-crystallizing heavy minerals in subaerial lava flows.

4. They may have originated as segregations of early-crystallizing heavy minerals in lava temporarily impounded in a shallowseated magma chamber before reaching the surface.

The constant association of local rocks-granite, schist, and vein quartz-with the ultramafic inclusions seems to favor the first hypothesis. No large bodies of ultramafic rocks, however, were found by me in the Imuruk Lake area, and none have been reported in nearby parts of Seward Peninsula.

Small bodies of altered pyroxenite and gabbro are common in southwestern Seward Peninsula between Nome and Teller (Collier and others, 1908, p. $99-100$ and pl. 10; Moffit, 1913, p. 32-33) but there is little obvious similarity between these rocks and the dunite and opacite inclusions of the Imuruk Lake area. The least altered pyroxenite consists chiefly of augite and plagioclase and contains no olivine, whereas the inclusions contain little augite, no plagioclase, and much olivine. No opacite masses comparable in size with the opacite inclusions in the Imuruk Lake area were seen by me in the pyroxenite between Nome and Teller. It is unlikely, therefore, that the dunite and opacite inclusions are derived from shallowseated ultramafic bodies of pre-Quaternary age.

The hypothesis that the ultramafic inclusions are derived from the peridotite substratum of the earth's crust as suggested by Ross, Foster, and Myers (1954) seems untenable for the dunite and opacite inclusions in the Imuruk Lake area. If one assumes that inclusions having an initial angular form could be derived in this manner, it seems likely that the sharp edges would be destroyed by resorption during the long journey to the surface. Moreover, if the olivine masses are to be regarded as primary features of the enclosing magma, originating at the time and place that the magma itself originated, it is strange that ultramafic inclusions are found in only a few of the many flows in the Imuruk Lake area. Finally, the Ross-Foster-Myers hypothesis does not explain the constant association of inclusions of local crustal rocks with the ultramafic inclusions. 
The possibility that the olivine clots and opacite masses represent products of crystal settling within subaerial lava flows is eliminated by the following evidence: The angular form of many inclusions, which suggests a fragmental origin; the even distribution of the inclusions throughout the full thickness of flows in which the olivine clots and opacite masses occur; and the presence of inclusions in agglomerate and in a steep-sided thick endogenous dome at Virginia Butte, whose viscosity during extrusion must have been far too great permit such settling.

If the inclusion-bearing flows were assumed to have been detained in a shallow-seated magma chamber before final extrusion, the inclusions could be considered to represent fragments of a layer of earlycrystallizing heavy minerals segregated by settling. When the magma was expelled from the chamber during extrusion, it might then have disrupted this segregated layer. The minerals of the segregated layer presumably would be out of equilibrium with the remaining liquid and thus would be partly dissolved or enclosed by reaction rims. Flows that lack inclusions could be assumed to have traveled directly from the basaltic substratum to the surface without detention en route in a magma chamber.

These assumptions would explain the following peculiar petrographic features and gross field relations of volcanic rocks in the belt from Blueberry Dome to upper Trail Creek and the contrasting features of the volcanic rocks outside of this belt:

1. The volcanic rocks in the inclusion-bearing belt vary widely in composition (from mafic basalt to hypersthene andesite) and thus seem to be more highly differentiated than the olivine basalt and olivine andesite lavas found beyond the inclusionbearing belt.

2. Olivine phenocrysts in the volcanic rocks of the inclusion-bearing belt are generally embayed and surrounded by reaction rims, suggesting that the inclusion-bearing rocks were detained at some point en route to the surface long enough for earlyformed crystals to be considerably altered by their enclosing fluids; in contrast, olivine phenocrysts in the inclusion-free rocks are generally sharply defined and euhedral, suggesting that the inclusion-free magmas were extruded immediately after being formed, with little or no opportunity for reaction between early formed crystals and the enclosing fluids.

3. The presence of several endogenous domes, flows of block lava, and aa flows indicate high viscosities, relatively low temperatures, and loss of dissolved gases during the extrusion of the volcanic rocks in the inclusion-bearing belt, suggesting deten- 
tion of the magma at shallow depth prior to extrusion. Low flow fronts, large horizontal extent of individual flows, and an overwhelming predominance of pahoehoe lava among the volcanic rocks beyond the inclusion-bearing belt indicate low viscosities, relatively high temperatures, and an abundance of dissolved gases and suggest rapid and uninterrupted movement of lava to the surface from great depths.

The field relations and petrographic data suggest that inclusionbearing lavas were impounded prior to extrusion in one or more shallow-seated reservoirs long enough for marginal portions of the magma to begin to crystallize and adhere to the wall rocks and for olivine, opacite, and a little pyroxene to crystallize and settle to form a basal layer of dunite. From time to time, part of the impounded magma was ejected from the chamber with sufficient violence to disrupt and engulf part of the dunite segregate, as well as fragments of the wallrock. The petrography and the gross features of the inclusion-free flows suggest, on the other hand, that they are composed of primitive basalt that traveled quickly and directly from great depths to the surface.

\section{STRUCTURAL FEATURES}

Tectonic disturbances of late Cenozoic age have played a signicant role in shaping the topography of the Imuruk Lake area and of nearby parts of Seward Peninsula. The major features resulting from the tectonic activity are broad structural highs and lows whose forms are not known in detail; examples include a probable faulted arch on the site of the Bendeleben Mountains, a structural basin on the site of the Kuzitrin flats, and a structural trench on the site of the Koyuk Valley.

Smaller but more obvious products of the tectonic activity are represented by a system of young fault scarps in the Imuruk Lake lava plateau, by warped shoreline features at Imuruk Lake, by a warped lake basin southwest of the head of the Goodhope River, and by the distribution pattern of the volcanic vents.

A structural arch of late Cenozoic age is postulated on the site of the Bendeleben Mountains on the basis of the following evidence: The widespread distribution of the late Tertiary erosion surface on ridge tops; an apparent continuation of the same erosion surface in sweeping, little-dissected slopes that descend northwestward to dip beneath sediments of late Pleistocene age in the Kuzitrin flats; and an apparent continuation of the same surface that descends northward to dip beneath the volcanic rocks in the Imuruk Lake lava plateau. The outline of the Bendeleben Mountains does not 
coincide closely with that of any bedrock unit; and thus the highland cannot be explained adequately as being the product of differential erosion. The south front of the Bendeleben Mountains is a young fault scarp (pl. 2); scarplets that represent part of this frontal fault system cut moraines of Nome River (Illinoian) and Salmon Lake (Wisconsin) age in many places, and locally they cut Recent alluvial fans.

A structural basin on the site of the Kuzitrin flats is postulated because the late Tertiary erosion surface appears to slope toward the center of the flats from the Bendeleben Mountains on the southeast and from the Seward Peninsula uplands on the west and northwest. The late Tertiary erosion surface dips under the Kougarok gravel in the northwestern and western part of the flats, and the Kougarok gravel appears to dip, in turn, beneath sediments of late Pleistocene age along the Noxapaga and Kuzitrin Rivers. A placer-mine shaft near Dahl Creek (pl. 2) extended through the Kougarok gravel to within 50 feet of sea level without reaching bedrock (Collier and others, 1908, p. 302). The outline of the Kuzitrin flats transects the strike of the limestone, schist, and gneiss units that underlie adjoining highlands, indicating that the flats probably were not excavated by differential erosion of a weak bedrock unit.

A structural trench is postulated on the site of the Koyuk River Valley because the south side of the valley is bounded by normal - faults in many places between the head of the Koyuk River and a point 24 miles to the east-southeast (pls. 2,4 ) and because the trend of the valley seems to transect: the trend of the limestone and schist units in adjoining highlands.

The late Cenozoic faults in the Imuruk Lake lava plateau are expressed as escarpments, locally as high as 100 feet, traceable for as much as 3 miles (an example, erroneously interpreted as the steep front of a lava flow, is shown on plate 31 of Hopkins, Karlstrom, and others, 1955). In most places, the escarpments are covered with loose rubble at the angle of repose; however, solid bedrock is exposed in a few places along the southeast shore of Imuruk Lake, and the escarpments can thus be shown to transect the internal structure of the lava flows.

Most of the recognized faults belong to a northwest-trending system extending from Blueberry Dome and Koyuk River Valley to Cottonwood Creek and the upper valley of the Goodhope River (pl. 4). Faults in the northwest-trending system delineate a possible graben on the site of the upper Koyuk River Valley, a broad vaguely defined graben occupied by Imuruk Lake, and a sharply 
defined horst on the site of Hoodoo Hill. The Imuruk Lake graben is aligned with and may represent a continuation of the Koyuk trench. The northwest-trending faults cut lava flows of the Imuruk and Gosling volcanics, but no fault scarps are recognized cutting the Camille or the Lost Jim flows. The faults were certainly active until late Wisconsin time but may not have been active during the last ten or fifteen thousand years.

The presence of a north-northeast-trending system of faults in the northeast corner of the area is suggested by several linear stream courses and linear boundaries between different vegetation types on Kettle Dome, by small scarps east of the head of the Kugruk River, and by topography suggestive of tilted fault blocks in the two ridges underlain by Paleozoic rocks between the Kugruk River and the head of the east fork of the Burnt River.

Irregular warping of the crustal blocks delineated by the late Cenozoic faults is suggested by deformed shorelines of Imuruk Lake (Hopkins, 1959b) and by the gently sloping floor of a large drained lake south of the head of the Goodhope River. One deformed area in Salix Bay seems to have been tilted southwestward, perhaps reflecting drag along the northwest-trending faults that extend from Nimrod Hill to Twincairn Butte. The remainder of the basin of Imuruk Lake appears to have been tilted southeastward, and the basin of the drained lake 10 miles to the northwest seems to have been tilted northwestward by the development of an arch whose. axis extends roughly at right angles to the trends of nearby faults. Isobases on these deformed surfaces are shown on plate 4 .

The deformation recorded by the warped shorelines of Imuruk Lake took place in 2 or 3 stages. The earliest interval, recorded by the deformation of the old wave-cut scarp of probable Illinoian age, resulted in the uplift and local southwestward tilting of the area of Granite Bay and Salix Bay; the later interval, indicated by the warping of the intermediate terraces of Wisconsin age, resulted in the development of the arch between Imuruk Lake and the drained lake 10 miles to the northwest; in the southeastward tilting of Imuruk Lake; and finally in the blocking of the outlet to the Noxapaga River and the initiation of drainage to the Kugruk River. The lowest terraces at Imuruk Lake are not tilted, and consequently the lake basin is believed to have been stable during at least the later part of Recent time.

The volcanic vents rarely lie in sharply defined alinements; however, they do tend to cluster in major northwest-trending swarms and minor northeast-trending swarms generally parallel to the two 
systems of faults observed in the Imuruk Lake area. One exceptionally well-defined alinement is expressed by six vents trending northeastward from the west end of Kuzitrin Lake to the head of the Koyuk River. None of the vents lies precisely on the trend of any observed fault. The surface faults appear not to have furnished channelways through which magmatic material moved to the surface, although both the surface faults and the northwest-trending swarms of vents may be related to a single.system of deep-seated fractures.

The Imuruk Lake area has been the site of mild tectonic activity throughout late Cenozoic time. The postulated Bendeleben arch, the Kuzitrin basin, and the Koyuk trench probably originated in late Miocene or early Pliocene time during an early phase of widespread orogenic movements that ended the evolution of the late Tertiary surface and that eventually brought the Bering and Chukchi Seas into existence as marine basins. The Kougarok gravel appears to have been deposited in the Kuzitrin flats as a result of the steepening of stream gradients in the uplands to the northwest that resulted from these orogenic movements. Active faulting has continued at the south front of the Bendeleben Mountains through Nome River (Illinoian) and Salmon Lake (Wisconsin) times into Recent time. A series of northeast- and northwest-trending faults was initiated in the Imuruk Lake lava plateau presumably during the later part of Pleistocene time; during Salmon Lake time a crustal block bounded by northeast-trending faults was buckled in a northwest-trending fold. The distribution pattern of the volcanic vents suggests that these vents are related to deep-seated major northwest-trending: faults and minor northeast-trending faults, but the observed surface faults seem not to have been the conduits through which the lava reached the surface.

\section{GEOLOGIC HISTORY}

The Imuruk Lake area, and probably all of Seward Peninsula, lay below sea level and received marine sediments throughout much of Paleozoic time. The metasediments exposed in the-Imuruk Lake area record two long intervals during which clastic sediments consisting chiefly of limy and carbonaceous clay were deposited, separated by a period during which a thick layer of limestone accumulated.

The marine sediments of the Imuruk Lake area and of most other parts of Seward Peninsula were folded and subjected to low-grade metamorphism at some time during late Paleozoic or early to middle Mesozoic time. Later, and possibly during an entirely distinct orogenic episode in Late Jurassic or. Early Cretaceous time, the 
low-grade metamorphic rocks were invaded by magmatic material and by associated fluids. Several plutons of quartz monzonite crystallized from the magmatic material, and the low-grade metasediments adjoining the plutons were metasomatically altered to higher grade metamorphic rocks of the amphibolite facies.

During most of the Tertiary period Seward Peninsula was a stable upland area near the center of a broad landmass extending from Alaska to Siberia across the present shallow portions of Bering and Chukchi Seas. During this interval the region was the site of longcontinued stream erosion rather than of sediment accumulation. By late Tertiary time, subaerial erosion had reduced the region to a rolling upland having a relief in most places of only a few hundred feet.

The planation of the erosion surface was brought to a halt by widespread but mild crustal movements that began during late in the Miocene or early in the Pliocene epoch and that have continued until the present time in some parts of Seward Peninsula. Differential warping in the Imuruk Lake area resulted in the lowering of the Kuzitrin basin nearly to and perhaps below sea level, in the raising of the Bendeleben arch, and probably in the formation of a structural trench on the site of the Koyuk River Valley. Stream gradients were steepened, base level was brought much nearer to the Imuruk Lake area, and streams draining the Bendeleben Mountains and the Seward Peninsula uplands began to excavate deep valleys in the deformed late Tertiary erosion surface. A sheet of alluvial gravel, the Kougarok gravel, accumulated where newly excavated valleys in the Seward Peninsula uplands debouched into the northwest side of the Kuzitrin Basin, and the earliest of the late Cenozoic basaltic lava flows-the Kugruk volcanics-were extruded in what is now the Imuruk Lake lava plateau.

The climate was still mild and temperate during the deposition of the lower and middle members of the Kougarok gravel and during the emplacement of the lava flows of the Kugruk volcanics in Pliocene time. Bedrock that was not subjected to active erosion was weathered to depths of several tens of feet, and the landscape was clothed in forest vegetation consisting of a mixture of coniferous and deciduous trees, including representatives of several genera that now reach their northern limits in latitudes $5^{\circ}$ to $15^{\circ}$ south of Seward Peninsula.

Continuing crustal movements in western Alaska resulted, by late Pliocene time, in the submergence below sea level of large areas to the south, west, and north of Seward Peninsula, forming the 
present marine basins of Bering and Chukchi Seas and Bering Strait (Hopkins, 1959a).

The climate cooled with the inception of the Pleistocene epoch; the upper member of the Kougarok gravel, which accumulated at a time when spruce and poplar grew in the Imuruk Lake area, may reflect renewed uplift and stream erosion in the Seward Peninsula upland during early Pleistocene time. Volcanic activity continued unabated, and lava flows of the Imuruk volcanics accumulated to a depth of several hundred feet in the Imuruk Lake lava plateau, burying the rolling hills and shallow valleys of the late Tertiary erosion surface. Some of the earliest flows of the Imuruk volcanics invaced the shallow valleys that had begun to be cut into the Seward Peninsula uplandis north of the lava plateau. As dissection continued and the valleys were deepened, these early lava flows were left as benches high on the valley walls.

The climatic history of early Pleistocene time prior to the Nome River (Illinoian) glaciation is not known in detail. Strata exposed in placer-mine workings at Iron Creek, 40 miles southwest of the Imuruk Lake area (fig. 1), record at least one early Pleistocene glaciation, followed by an interglacial interval during which spruce and Douglas fir grew on Seward Peninsula, followed in turn by the Nome River glaciation.

The Nome River glaciation is the most intense glacial event indicated in the geologic record of Seward Peninsula. Glaciers originating in the Bendeleben Mountains pushed down the valleys to the south edge of the Imuruk Lake lava plateau and down other valleys well onto the southeastern part of the Kuzitrin flats. The exposed surfaces of lava flows of the Imuruk volcanics were brecciated by frost action and reduced to vast areas of loose rubble. Winds sweeping across the Kuzitrin flats picked up silt from the barren flood plains in front of the glaciers and carried it northward and northeastward to be deposited in and on the frost-brecciated surfaces of lava flows of the Imuruk volcanics, on the sloping surface of the Kougarok gravel, and an older bedrock wherever exposed.

By the end of the Nome River glaciation, the Imuruk Lake area had acquired much of its present appearance. A thick cover of newly deposited windblown silt covered all surfaces except the youngest flows of the Imuruk volcanics and the areas that had until recently lain buried beneath the glaciers of Illinoian age. Imuruk Lake probably had come into existence by this time in a deep undrained basin between lava flows on the Imuruk Lake. lava plateau. As the Nome River glaciation progressed, windblown silt was deposited directly in the lake, and reworked: silt washed in from 
the adjoining slopes and began to fill the lake basin, thereby partially sealing the bottom from leakage into the underlying lava flows. As a result the lake overflowed a low pass at the northwest corner into Carex Creek, a tributary of the Noxapaga River.

The Nome River glacial interval presumably was followed by a major interglacial interval during which the climate was somewhat warmer than at present and during which the level of Imuruk Lake was lowered as a result of increased evaporation. The oldest lava flows of the Gosling volcanics probably were extruded during this warmer interval between the Nome River and the Salmon Lake glaciations. Tectonic movements that probably began near the end of the Nome River glaciation or during the ensuing interglacial interval resulted in the formation of a series of northwest-trending fault scarps cutting lava flows of the Imuruk volcanics and delineating a narrow horst on the site of Hoodoo Hill and a broad graben in the area of Imuruk Lake.

With the onset of the Salmon Lake (Wisconsin) glaciation, small glaciers formed in the higher parts of the Bendeleben Mountains. The newly extruded lava flows of the Gosling volcanics were subjected to vigorous frost riving, and their surfaces were thoroughly brecciated to form extensive areas of loose rubble. Silt again was transported by winds blowing across the braided flood plains of streams flowing from the glaciated valleys into the Kuzitrin flats and was deposited amongst the frost-rived rubble on the Gosling volcanics. Evaporation was reduced, and Imuruk Lake rose again to the level of its outlet and emptied westward to the Noxapaga River. Silt and water-logged peat accumulated in the lake to form what are now the older group of intermediate terraces. An explosive volcanic eruption at some unidentified vent in the Imuruk Lake lava plateau resulted in the deposition of a thin sheet of brown or pink ash over most of the area between Imuruk Lake, the Noxapaga River, Andesite Creek, and Sandy Lake.

A brief warm interval during the Salmon Lake glaciation apparently resulted in the temporary lowering of the level of Imuruk Lake. Lake level then rose again during late Salmon Lake time, and the lower group of intermediate terraces was formed. The Camille lava flow was erupted late in this second cold phase of the Salmon Lake glaciation. The newly solidified surface of the flow was briefly but vigorously attacked by frost action, and then a general warming of the climate about 10,000 years ago brought frost riving to an end in high well-drained sites in the Imuruk Lake area.

Renewed crustal movements in late Wisconsin or early Recent time resulted in the fault scarps that locally cut lava flows of the Gosling 
volcanics and in the warping of the floor of the Imuruk graben along the northern and western shores of Imuruk Lake. The area of the former outlet from Imuruk Lake to a headwater tributary of the Noxapaga River was sharply arched, and a new outlet was cut eastward to the Kugruk River. During a later interval of warm summers the level of Imuruk Lake was lowered at least a few feet below the present level as a result of increased evaporation. Still more recently, the climate became cooler than at present, and the lake level rose briefly 3 to 5 feet above the present level and then fell back to the present position. A violent and prolonged eruption at some time during this series of events gave rise to the Lost Jim lava flow.

\section{PERMAFROST}

Perennially frozen ground is present everywhere in the Imuruk Lake area except beneath the courses of large streams and the beds of the larger lakes. The upper surface of the perennially frozen ground lies at depths of 1.0 to 1.5 feet in peat underlying poorly drained areas, 1.5 to 3.0 feet in windblown silt, 3 to 6 feet in areas where sand or gravel are exposed at the surface, and 5 to 10 feet in areas where bedrock, unbroken basalt, or basaltic rubble lie at the surface. Permafrost in this part of Alaska commonly extends to depths of 200 feet or more (Hopkins, Karlstrom, and others, 1955, p. 121), but a diamond-drill hole 150 feet deep in lava flows of the Imuruk volcanics about 7 miles east of Lava Lake passed through basalt in which fractures were filled with ice into unfrozen basalt at a depth of 70 feet (Ted Matthews, consulting engineer, oral communication, 1945). Hydrologic evidence, discussed later, suggests that the lava flows in the Imuruk Lake area contain interconnecting thawed zones that allow relatively free circulation of ground water.

Stratigraphic evidence from nearby areas suggests that certain ice wedges originated at least as long ago as early Wisconsin time; thus, some of the frozen ground is very old; however, the fact that permafrost, is also present in the Lost Jim lava flow indicates that new permafrost has formed in previously unfrozen material during the last few thousand years.

\section{GROUND-WATER HYDROLOGY}

The irregular distribution of permafrost, the irregular initial topography of the lava flows, and the difference in permeabilities of the various geological materials found in the Imuruk Lake area combine to create a complicated ground-water regimen. Examples of subterranean drainage are abundant; bodies of perched ground water are widespread; and springs are numerous. Ground water 
evidently circulates freely in the lava flows, in the metalimestone, in the flood-plain gravel of the larger streams, and probably in the Kougarok gravel; the schist and granite are nearly impermeable, as are the windblown silt, the stratified silt and peat, and the lacustrine silt.

\section{ALLUVIAL GRAVEL}

Evidence elsewhere on Seward Peninsula suggests that appreciable underflow moves through the gravel beneath the channels and flood plains of the larger streams, such as the Noxapaga and the Kuzitrin Rivers (Hopkins, Karlstrom, and others, 1955, p. 121-122).

\section{METALIMESTONE}

Metalimestone in the Imuruk Lake area and elsewhere on Seward Peninsula apparently contains interconnected openings (probably joints widened by solution) through which ground water circulates (Hopkins, Karlstrom, and others, 1955, p. 122). Streams crossing limestone areas commonly lose most of their water at lowwater stages through seepage into their beds; flowing water reappears in the stream beds near the downstream edges of the limestone belts.

Large springs emerge from metalimestone in many places on Seward Peninsula; they are especially common near the downstream ends of valley reaches that cross metalimestone belts. An example in the.Imuruk Lake area is found on the upper Inmachuk River, where springs yielding 8 or 9 -second-feet emerge from the steep west wall of the valley about 30 feet above stream grade. (The springs are illustrated in Moffit, 1905, pl. 3.) Much of the discharge emerges from a single open fracture about 1 foot in diameter, but smaller springs are distributed over an area of about 2,000 square feet. The temperature was not measured but is estimated to be about $50^{\circ} \mathrm{F}$.

\section{KOUGAROK GRAVEL}

No subterranean drainage was seen in areas underlain by Kougarok gravel; but a spring having an estimated discharge of about 3 second-feet emerges at the lignite mine on Turner Creek, suggesting that the Kougarok gravel is capable of transmitting appreciable quantities of ground water. The Turner Creek spring emerges in a craterlike pond nearly surrounded by a hillock of Kougarok gravel and in a smaller pond at the base of the hillock, adjacent to the flood plain of Turner Creek. Odorless gas bubbles vigorously from more than 100 sites in the two ponds, and the water tastes faintly of soda. The ponds have an estimated temperature of about $50^{\circ} \mathrm{F}$. 


\section{IMURUK VOLCANICS}

The Imuruk volcanics are insulated from surface water in most places by a thick and nearly impermeable blanket of windblown silt, but small surface streams flowing on the silt commonly terminate in thaw sinks (closed depressions resulting from subsidence after the thawing of ice wedges in perennially frozen silt) that extend through the silt into underlying frost-rived basalt. The streams percolate into rubble exposed in linear or polygonal trenches on the floors of the sinks that evidently represent the sites of former ice wedges. Examples are illustrated in Hopkins (1949) and in Hopkins, Karlstrom, and others $(1955$, pl. 31). A small volume of water was observed flowing out of Imuruk Lake through a trench on the site of an ice wedge that intersects the east shore. The water flowed into a thaw sink about 100 feet inland and percolated into the ground in the floor, which lay a few feet below the level of the lake.

Surface water also percolates into the rubble exposed along the larger fault scarps in the Imuruk volcanics. Imuruk Lake loses an estimated 2 second-feet through two short channels that drain with perceptible current into the basalt rubble along the fault scarp at the southwest shore. Considerably more water may be lost by less easily detectable percolation into the coarse rubble that lines the shore for nearly a mile in this area.

Though surface water percolates freely into the Imuruk volcanics wherever the silt cover is breached, the lava flows evidently are not saturated. The 150-foot drill hole, 7 miles east of Lava Lake, reached dry unfrozen basalt below a depth of 70 feet, and considerable difficulty in drilling was experienced owing to loss of drilling water (Ted Matthews, consulting engineer, oral communication, 1945). Imuruk Lake, most smaller lakes, and most surface streams are insulated from the underlying lava flows by silty sediments and represent perched bodies of surface water. Perched bodies of ground water may also lie on buried layers of windblown silt and on massive central parts of thick buried lava flows.

Part of the ground water in the Imuruk volcanics emerges in springs along the walls of the deep canyons of the Kugruk, Burnt, Pinnell, and Goodhope Rivers. Large springs having an estimated discharge of 18 or 19 second-feet emerge from the base of a lava flow on the east side of the Kugruk River canyon, just north of the gully cut by the outlet from Imuruk Lake (Henshaw and Parker, 1913, p. 123). Springs having a discharge of 1 second- 
foot and a measured temperature of $34^{\circ} \mathrm{F}$ were found by me near the point where the Goodhope River first cuts through the Imuruk volcanics into the underlying schist. Other springs are probably present in the canyons of all the north-flowing streams.

Several large springs discharge from the virtually undissected surfaces on the Imuruk volcanics. The Noxapaga River heads in a cluster of warm springs issuing from a large, amphitheatrelike depression just west of Andromeda Cone (Hopkins, Karlstrom, and others, 1955, pl. $43 \mathrm{C}$ ). The springs at Andromeda Cone were not visited on the ground, but bush pilots report that the area of the springs remains free of snow during most of the winter. Two other clusters of springs emerge from Imuruk volcanics north of the bedrock ridge that extends northwestward from Kettle Dome.

\section{GOSLING VOLCANICS, CAMILLE LAVA FLOW, AND LOST JIM LAVA FLOW}

The younger volcanic formations lack a blanket of windblown silt; consequently, most of the moisture falling on their surfaces infiltrates promptly. Surface water is almost lacking. Additional recharge occurs in places where the younger volcanic formations have invaded valleys in the silt mantle overlying the Imuruk volcanics; the minor streams flowing in the valleys enter the margins of the younger volcanic units with little or no ponding. The younger volcanic rocks evidently contain considerable ground water perched on the silt mantle that covers the underlying Imuruk volcanics; the ground water seems to move rather freely in courses determined by the buried topography on the silt, and it reappears at the surface as small clear streams in the places where the buried valleys emerge from beneath the younger lava flows. The groundwater table in much of the Lost Jim lava flow is at least 20 feet beneath the surface, but water table lies at considerably shallower depths in most places in the Gosling volcanics and the Camille lava flow.

Ephemeral lakes occupy a few depressions on the younger volcanic formations. Study of aerial photographs and of high-water marks in some dry basins visited: on the ground indicates that the water level in many lakes fluctuates 5 feet or more. A collapse sink, 60 feet deep, on the Lost Jim flow, about a mile west of Lost Jim Cone, contained a lake when photographed from the air in October 1946 but was dry when visited in September 1947. Highwater marks observed on the walls of the sink in 1947 indicate that at times water has stood as much as 30 feet above the floor. 


\section{MINERAL RESOURCES GOLD PLACERS}

Gold placers have been mined on a small scale since 1900 along tributaries of the Pinnell and the Noxapaga Rivers. The first discovery of workable gold placers in northern Seward Peninsula was made on Old Glory Creek in 1900 (Moffit, 1905, p. 54) and mining continued there and in Nelson Gulch intermittently for about ten years. The gold was recovered from auriferous gravel, a few feet thick, beneath the channel and flood plain of Old Glory Creek and in the narrow bedrock gully of Nelson Gulch. Gold concentrates from Old Glory Creek are reported to have contained a small quantity of cassiterite.

Auriferous gravel was discovered beneath the lava flows high on the walls of Perry Creek valley, but no great amount of gold was produced (Henshaw, 1910, p. 368).

Gold was discovered on Goose Creek, a minor tributary of the Noxapaga River in 1900, and within the next few years gold placers were found on Grouse Creek, Black Gulch, and Frost Creek (Collier and others, 1908, p. 314). The small patch of Kougarok gravel a few hundred yards up the Noxapaga River from the mouth of Goose Creek (fig. 1) was prospected and found to be sparsely auriferous (Frank Whaley, miner, oral communication, 1948). Mining has continued on a modest scale in the Noxapaga River valley into the 1950's; during my visits in 1947 and 1948, mining was in progress on Winona Creek, Grouse Creek, Black Gulch, Buzzard Gulch, and Goose Creek. The placers consisted of auriferous stream gravel a few feet thick overlain by 20 to 30 feet of frozen peat and silt (fig. 8).

The gold in the placers in the Imuruk Lake area is evidently derived from quartz-calcite veins that are abundant in the schist bedrock of the producing areas.

\section{LIGNITE}

The lignite member of the Kougarok gravel was mined near the junction of Turner Creek and the Noxapaga River during the early 1900 's for local use in thaw boilers and as a household fuel, but it is said to have had a high ash content and poor heating value (Jules Gunderson, miner, oral communication, 1948). Because it consists of lignified wood in a friable, sooty matrix and because the overlying gravel is loose and uncemented, the Turner Creek lignite would be difficult to mine. Diesel oil, brought in by tractors, has been the principal source of energy and heat in recent years, and the lignite is unlikely to find even a local use in the future. 


\section{DIATOMITE}

An apparently extensive deposit of diatomite, or diatomaceous earth, of potential use as a light-weight filler or insulating material, is represented by three exposures in the valley of Andesite Creek. The diatomite occupies the floor of a former lake that was invaded by the Lost Jim lava flow; the deposit is probably continuous beneath the tongue of the Lost Jim flow that separates the three exposures.

The northeasternmost exposure, due south of Lava Lake, consists of diatom tests containing only a few percent of admixed mineral grains and little or no organic material. The diatomite is dead white when dry and pale yellowish gray when wet. The color darkens southwestward, presumably because of increasing quantities of organic material; the southwesternmost exposure in the valley of Andesite Creek is chocolate brown. Basalt boulders are scattered throughout the diatomite and are especially abundant in the southwestern exposure.

The pure diatomite of the northeastern exposure occupies an area about 2,500 feet long and 1,000. feet wide; about half of the exposed area is occupied by a small lake, beneath which the diatomite appears to extend. The less pure diatomite in the exposures to the southwest occupies a total area of about 375,000 square feet. The diatomite ranges in thickness from 4 to 10 feet in stream and lake banks, but the base of the deposit is nowhere exposed. If the diatomite. is continuous beneath the tongue of the Lost Jim lava flow that separates the three exposures, it is present throughout an area of about one-tenth of a square mile.

\section{LITERATURE CITED}

American Antiquity, 1950, Notes and news: Am. Antiquity, v. 15, p. 264-265. 1951, Notes and news: Am. Antiquity, v. 16, p. 285.

Brooks, H. K., .1954, The rock and stone terms limestone and marble: Am. Jour. Sci., v. 252, p. 755-760.

Benninghoff, W. S., Hopkins, D. M., and Holmes, G. W., 1961, Newly recovered upper Tertiary nonmarine sediments in Alaska and northwestern Canada [abs.], in v. 1 of Geology of the Arctic: Univ. Toronto Press, p. 598.

Cass, J. T., 1959, Reconnaissance geologic map of the Norton Bay quadrangle, Alaska: U.S. Geol. Survey Misc. Geol. Inv. Map I-286.

Cathcart, S. H., 1922, Metalliferous lodes in southern Seward Peninsula: U.S. Geol. Survey Bull. 722-F, p. 163-261.

Collier; A. J., 1902; A reconnaissance of the northwestern portion of Seward Peninsula, Alaska: U.S. Geol. Survey Prof. Paper 2, 68 p.

Collier, A. J., Hess, F. L.; Smith, P. S., and Brooks, A. H., 1908, The gold placers of parts of Seward Peninsula, Alaska: U.S. Geol. Survey Bull. 328, $343 \mathrm{p}$. 
Dall, W. H., 1870, Alaska and its resources: London, Sampson Low, Son, and Marston, $627 \mathrm{p}$.

Dücker, Alfred, 1937, Über Strukturboden im Riesengebirge-ein Beitrag zum Bodenfrost- und Lössuproblem: Deutsche geol. Gesell. Zeitschr., v. 89, p. 113-129.

Dutro, J. T., and Payne, T. G., 1954, Geologic map of Alaska: U.S. Geol. Survey.

Fradkina, A. F., 1958, Sporovo-pyl'tsevye kompleksy Neogenovykh otlozhenij bassejna nizhnego techniya $R$. Aldan i po razrezu Namskoj opornoj ekvazhinf [Spore-pollen complexes from Neogene deposits in the basin of the lower Aldan River and cores from the Namtsy abutment test bores], in Voprosy geologii i neftegazonoshosti Yakutskoj A.S.S.R. [Problems of geology and petroleum-gas of Yakutsk A.S.S.R.]: Moscow, U.S.S.R., State Techn. Pub., p. 80-90.

Gault, H. R., Killeen, P. L., West, W. S., and others, 1953, Reconnaissance for radioactive deposits in the northeastern part of the Seward Peninsula, Alaska, 1945-47 and 1951: U.S. Geol. Survey Circ. 250, 31 p.

Goddard, E. N. (Chm.), and others, 1948, Rock-color chart: Washington, D. C., Natl. Research Council; reprinted by Geol. Soc. America, 1951.

Goodspeed, G. E., 1948, Origin of granites: Geol. Soc. America Mem. 28, p. $55-78$.

Harrington, G. L., 1919a, Graphite mining in Seward Peninsula: U.S. Geol. Survey Bull. 692-G, p. 363-368.

$-1919 \mathrm{~b}$, The gold and platinum placers of the Kiwalik-Koyuk region: U.S. Geol. Survey Bull. 692-G, p. 369-400.

Henshaw, F. F., 1910, Mining in Seward Peninsula: U.S. Geol. Survey Bull. 442-I, p. 353-371.

Henshaw, F. F., and Parker, G. L., 1913, Surface water supply of Seward Peninsula, Alaska: U.S. Geol. Survey Water-Supply Paper 314, 317 p.

Hopkins, D. M., 1949, Thaw lakes and thaw sinks in the Imuruk Lake area, Seward Peninsula, Alaska: Jour. Geology, v. 57, p. 119-131.

Hopkins, D. M., 1956, Structure and history of a basalt lava flow in Alaska [abs.]: Alaskan Sci. Conf., 4th, Juneau 1953, Proc., p. 237.

$-1959 \mathrm{a}$, Cenozoic history of the Bering land bridge: Science, $\nabla .129$, p. 1519-1528.

1959b, History of Imuruk Lake, Seward Peninsula, Alaska: Geol. Soc. America Bull. v. 70, p. 1033-1046.

1959c, Some characteristics of the climate in forest and tundra regions in Alaska: Arctic, v. 12, p. 215-220.

Hopkins, D. M., and Benningoff, W. S., 1953, Evidence of a very warm interglacial interval on Seward Peninsula [abs.]: Geol. Soc. America Bull., v. 64 , p. 1435 .

Hopkins, D. M., and Giddings, J. L., Jr., 1953, Geological background of the Iyatayet archeological site, Cape Denbigh, Alaska: Smithsonian Misc. Coll., v. 121 , no $11,33 \mathrm{p}$.

Hopkins, D. M., Karlstrom, T. N. V., and others, 1955, Permafrost and ground water in Alaska: U.S. Geol. Survey Prof. Paper 264-F, p. 113-146.

Hopkins, D. M., MacNeil, F. S., and Leopold, E. B., 1960, The coastal plain at Nome, Alaska: a late Cenozoic type section for the Bering Strait region: Internat. Geol. Cong., 21st, Copenhagen 1960, Proc., pt. 4, p. 46-57. 
Hopkins, D. M., and Sigafoos, R. S., 1951, Frost action and vegetation patterns on Seward Peninsula, Alaska: U.S. Geol. Survey Bull. 974-C, p. 51-100.

Kindle, E. M., 1911, Faunal succession in the Port Clarence limestone, Alaska: Am. Jour. Sci., 4th ser., v. 32, p. 335-349.

Linton, D. L., 1949, Unglaciated areas in Scandinavia and Great Britain: Irish Geography, v. 2, p. 25-33.

Macdonald, G. A., 1949, Petrography of the island of Hawaii: U.S. Geol. Survey Prof. Paper 214-D, p. 51-96.

-1953, Pahoehoe, aa, and block lava: Am. Jour. Sci., v. 251, p. 169-191.

MacNeil, F. S., Wolfe, J. A., Miller, D. J., and Hopkins, D. M., 1961, Correlation of the Tertiary formations of Alaska: Am. Assoc. Petroleum Geologists Bull., v, 45, p. 1801-1809.

Mendenhall, W. C., 1901, A reconnaissance in the Norton Bay region, Alaska, in 1900: U.S. Geol. Survey Spec. Pub., p. 206.

Moffit, F, H.. 1905, The Fairhaven gold placers, Seward Peninsula, Alaska: U.S. Geol. Survey Bull. 247, 79 p.

1913, Geology of the Nome and Grand Central quadrangles, Alaska: U.S. Geol. Survey Bull. 533, 140 p.

Nichols, R. L., 1946, McCartys basalt flow, Valencia County, New Mexico: Geol. Soc. America Bull., v. 57, p. 1049-1086.

Péwé, T. L., 1951, An observation of windblown silt: Jour. Geology, v. 59, p. $399-401$.

Péwé, T. L., and others, 1953, Multiple glaciation in Alaska: U.S. Geol. Survey Circ. 289, 13 p.

Porsild, E. E., 1938, Earth mounds in unglaciated northwestern America: Geog. Rev., จ. 28, p. 46-58.

Quay, W. B., 1951, Observations on mammals of the Seward Peninsula, Alaska : Jour. Mammalogy, v. 32, p. 88-99.

Ross, C. S., Foster, M. D., and Myers, A. T., 1954, Origin of dunites and olivinerich inclusions in basaltic rocks: Am. Mineralogist, v. 39, p. 693-737.

Smith, P. S., 1909, The Iron Creek region: U.S. Geol. Survey Bull. 379, p. 302-354.

-1910, Geology and mineral resources of the Solomon and Casadepaga quadrangles, Seward Peninsula, Alaska: U.S. Geol. Survey Bull. 433, 234 p.

Smith, P. S., 1939, The areal geology of Alaska: U.S. Geol. Survey Prof. Paper 192, 99 p.

Smith, P. S., and Eakin, H. M., 1911, A geologic reconnaissance in southeastern Seward Peninsula and the Norton Bay-Nulato region, Alaska: U.S. Geol. Survey Bull. 449, 146 p.

Steidtmann, Edward, and Cathcart, S. H., 1922, Geology of the York tin deposits, Alaska: U.S. Geol. Survey Bull. 733, 130 p.

Taber, Stephen, 1943, Perennially frozen ground in Alaska; its origin and history: Geol. Soc. America Bull., v. 54, p. 1433-1548.

Troll, Carl, 1944, Strukturböden, Solifluktion, and Frostklimate der Erde: Geol. Rundschau, v. 34, p. 545-694.

Turner, F. J., 1948, Mineralogical and structural evolution of the metamorphic rocks: Geol. Soc. America Mem. 30, 342 p. 
U.S: Geological Survey; 1961; Geological Survey Research; 1961: U.S. Geol. Survey Prof. Paper 424-A, 194 p.

Walton; Matt, 1955, The emplacement of "granite": Am. Jour. Sci., v. 253, p. 1-18.

Wentworth, C. K., and Macdonald, G. A., 1953, Structures and forms of basaltic rocks in Hawaii: U.S. Geol. Survey Bull: 994, 98 p.

Williams, Howell, 1932, The history and character of volcanic domes: California Univ. Pub., Geol. Sci. Bull., v. 21, p. 51-146. 


\section{INDEX}

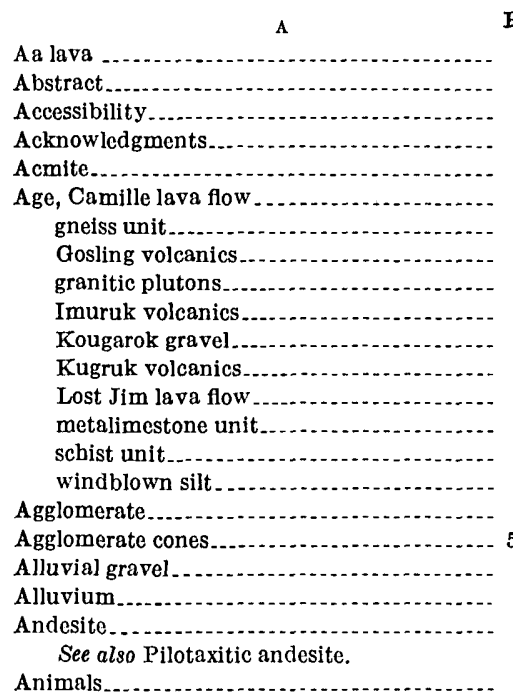

Apatite

A plite.

Augite. 76,77

A uriferous gravel. $30,32,42,94$

B

Basalt $47,72,73$

Basaltic andesite.

The Bat

Bendeleben Mountains

Bering-Chukchi platform

Bering land bridge.

Bibliography ...........

Biotite-hornblende-epidote gneiss.............

Biotite-schist

Braided streams................................

Brooks, A. H., quoted

Brown ash layer. $46,48,71$

\section{C}

Calcite-muscovite schist

Camille Cone

Camille lava flows

Carbonate grains

Cenozoic rocks.

Chemical analysis

Chlorite-calcite schist.

Chrysotile

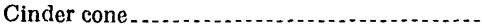

Climate.

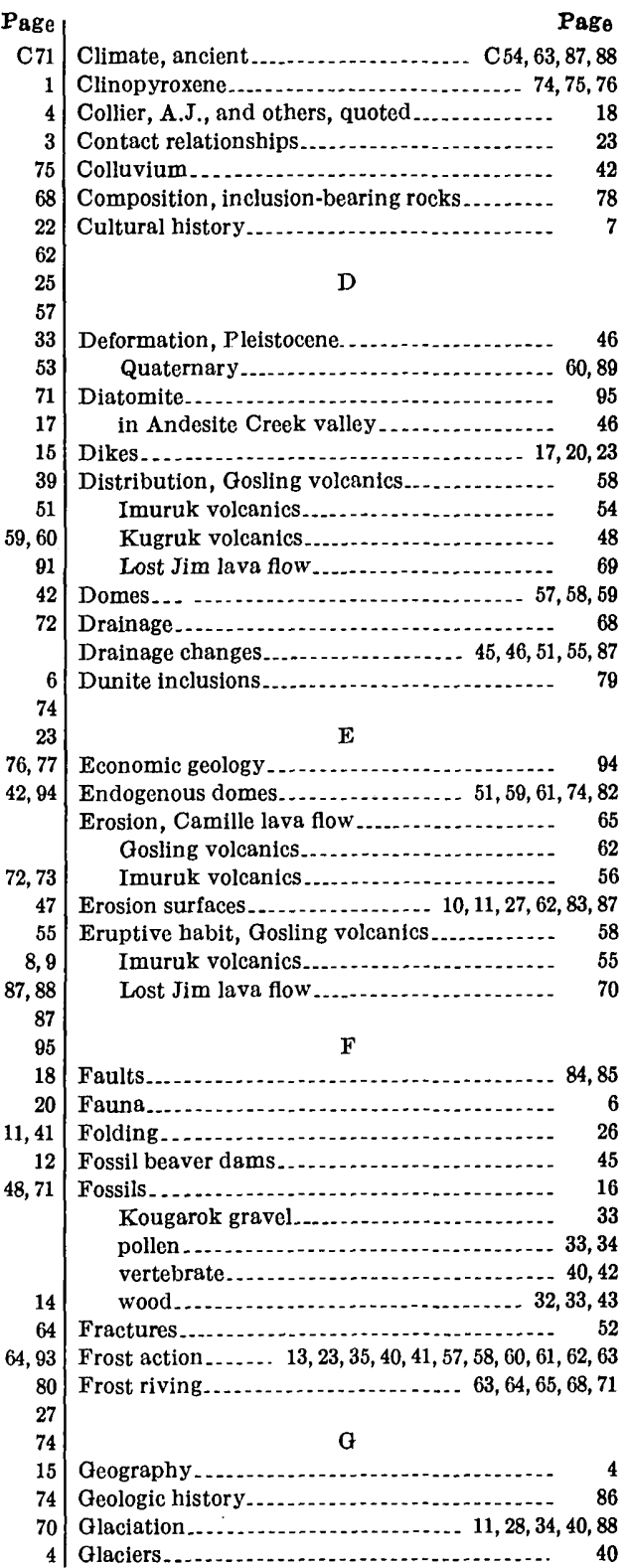




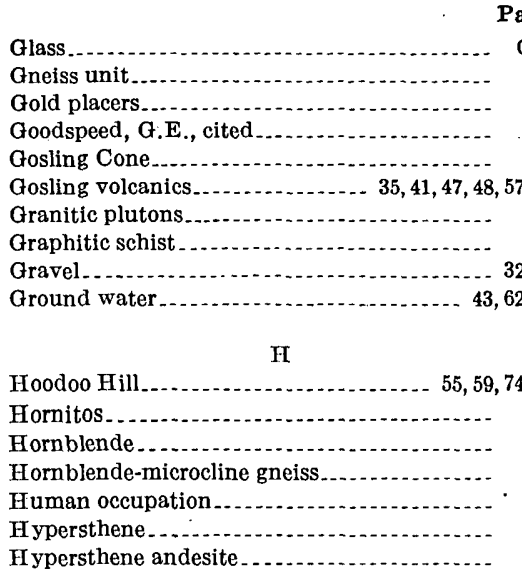

Ice-wedge polygons

Ice wedges

Icings, flood-plain.

Iddinsite .

Ilmenite.

Imuruk lake, lacustrine sediments

lava plateau

Imuruk volcanics. ....

Inclusion-bearing rocks

Introduction

Investigation, previous

Iron Creek glaciation

\section{$\mathrm{J}$}

Joints

\section{$\mathrm{K}$}

Kettle Dome $51,55,78$

Kigluaik group

Kougarok gravel

Kugruk plateau

Kugruk volcanics

Kuzitrin flats.

\section{L}

Lacustrine sediments..

Lakes, drained.

ephemeral

flled.

thaw .

Largo Ridge

Lichens.

Lignite.

Lithology, Camille lava flow gneis unit.

Gosling volcanics

granitic plutons.

Imuruk volcanics.

Kougarok gravel.

Kugruk volcanics

Lost Jim lava flow.

schist unit

metalimestone unit.

windblown silt
75 Location of area.

Page

C7

Lost Jim lava flow................. $9,35,48,68,75,88$

M

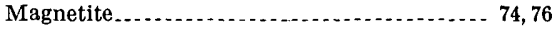

Marine sediments........................ 86

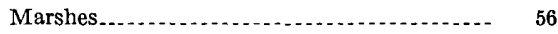

Mesozoic rocks........................... 13

Metalimestone.................... 13,16,17, 20,91

Metamorphism........................ 14, 21, 22

Microcline phenocrysts...................... 23

Mineral resources............................ 94

Mineralogy, windblown silt ................. 38

Modal composition ......................... 72

Moffit, F. H., cited ........................ 26

Mount Osborn glaciation ... . . . . . . . . . . . 28, 29

Muscovite schist........................... 15

Natrolite .................. 75

Nenana gravel................................ 33

Nome River glaciation.......... 28, $34,40,41,58,88$

Noxapaga River

Old erosion surface . . ........................ 11

Olivine..................... 74, 75, 76

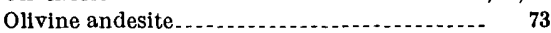

Olivine basalt............................ 74

Olivine phenocrysts ........................ 82

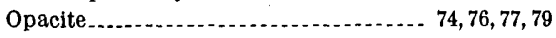

Origin, inclusion-bearing rocks............... 80 windblown silt....................... 39

$\mathbf{P}$

Pilotaxitic andesite

Q

Quartz-albite-biotite gneiss .................. 20

Quartz-biotite schist......................... 15

Quartz-calcite schist......................... 15

Radiocarbon dating ................ 33, 40,44

Regional geology . . .

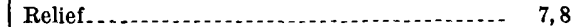

Rhododendron Cone..................... 56

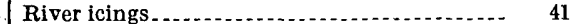

Rock monuments ......................... 9, 11, 26

Ross-Foster-Myers hypothesis............... 81

Salmon Lake glaciation .............. 10, 28, 35, 41, 89

4 Scapolite skarn .............................. 20

7 Schist unit ................................. 13

57 Sericite schist.............................. 15

23 Seward Peninsula uplands................... 8,11

54 Shear zone ................................. 26

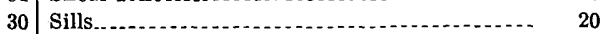

48 Skarn ...................................... 17, 20

68 Skeleton Butte............................ 61

14 Smith, P. S., and Eakin, H. M., quoted..... 21

16 Soils and weathered zones.. $30,31,32,42,48,49,53,56$

36 Springs ............................. 91, 92, 93 


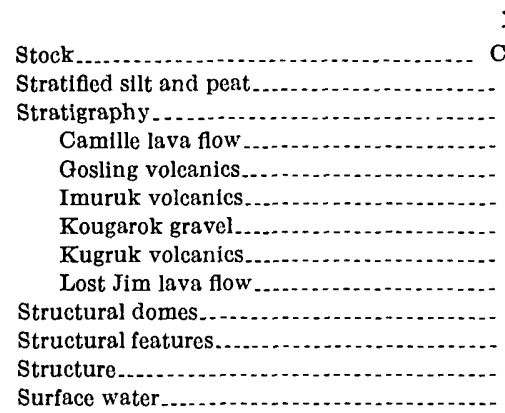

\section{$\mathrm{T}$}

Temperature

Tertiary erosion surface

Tertiary sediments

Textures.

Thaw lakes.

Thaw sinks

Tors. See Rock monuments.

Twin Calderas.

\section{U}

Page

C23, 26

Unconsolidated sediments

C29

64

57

54

30

48

68
26

83
26

26
92

92

Ungalik conglomerate

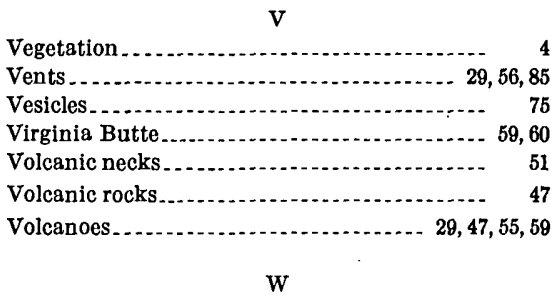

4 Weathering profile, Camille lava flow ......... 65

84
27 Gosling volcanics..................... 62

$27 \quad$ Imuruk volcanics........................ 56

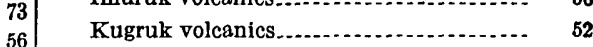

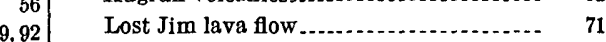

See also Soils and weathered zones.

${ }_{59}$ Windblown silt....... 13, 27, 31, 35, 43, 56, 57, 62, 64, 68 